\title{
Placing a Price on Pain and Suffering: A Method for Helping Juries Determine Tort Damages for Nonmonetary Injuries
}

\author{
Mark Geistfeld $\dagger$
}

TABLE of Contents

Introduction $\ldots \ldots \ldots \ldots \ldots \ldots \ldots \ldots \ldots \ldots \ldots \ldots \ldots \ldots \ldots \ldots \ldots \ldots \ldots \ldots, 775$

I. The Current System ........................... 781

II. Problems Created by the Current System .............. 783

A. Arbitrariness in Awards for Pain and Suffering ........ 783

B. Consequences of Arbitrary Pain-and-Suffering Dainages Awards .................................... 786

III. Analysis of Reform Proposals...................... 789

A. Caps or Ceilings .......................... 789

B. Schedules and Other Methods of Increasing Horizontal Equity .................................... 791

C. Abolishing Awards for Pain and Suffering in Contractual Settings ................................... 793

IV. A Justification for Full Compensation Under the Current System ................................... 796

A. Revising the Unrealistic Assumption of Perfect Information ................................

B. Revising the Unrealistic Assumption of Optimal

Compensation ............................... 800

C. Revising the Unrealistic Assumption of Perfect

Enforcement

Copyright @ 1995 California Law Review, Inc.

$\dagger$ Assistant Professor, New York University School of Law. B.A. 1980, Lewis \& Clark College; M.A. 1981, University of Pennsylvania; J.D. 1989, Ph.D. 1990, Columbia University. This paper was presented at the 1995 Annual Meeting of the Law and Economics Association and at the Law and Economics Workshop at the University of Pennsylvania. I would like to thank the participants in those sessions for their helpful comments. I am also grateful to Marcel Kahan, Lewis Kornhauser, and Ricky Revesz for their comments on an earlier version of this Article, and to Tasha Bouchard for her excellent research assistance. Special thanks to Janette Sadik-Khan for, among other things, impressing upon me the importance of relating theory to practice.

This research was supported by a generous grant from the Filomen D'Agostino and Max E. Greenberg Research Fund at the New York University School of Law. 
V. The Proper Measurement of Pain-and-Suffering Dainages in Contractual Settings ................................ 803

A. The Ex Ante Full-Coinpensation Award ............ 804

B. Harmonizing the Ex Ante Full-Compensation Measure with Case Law $\ldots \ldots \ldots \ldots \ldots \ldots \ldots \ldots \ldots \ldots \ldots . .610$

1. The Use of Matheinatical Formulas for Computing Pain-and Suffering Damages................... 810

2. Justifying the Ex Ante Full-Coinpensation Award as an Appropriate Measure of Full Compensation ..... 813

VI. The Measurement of Pain-and-Suffering Damages in Noncontractual Settings

A. Willingness to Accept Risk as an Appropriate Basis for

B. Practical Considerations: A Coinparison of Willingness to Accept Risk with Willingness to Pay to Elinninate Risk. .

C. The Appropriateness of Using Willingness to Pay to Eliminate Risk as the Basis for Determining Damages Awards for Torts Involving Noncontractual Relationships

VII. Tort Reform Reconsidered

A. Comparing the Ex Ante Full-Coinpensation Award to the Current Approach

B. The Ex Ante Full Compensation Award and Damages Schedules: The Jury as Survey Mechamism ........... 832

1. Market Prices for Physical Injuries.............. 832

2. Jury vs. Nonjury Surveys.................... 835

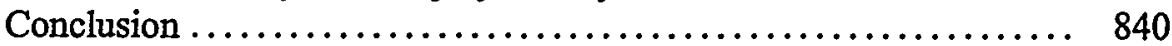

Appendix $\ldots \ldots \ldots \ldots \ldots \ldots \ldots \ldots \ldots \ldots \ldots \ldots \ldots \ldots \ldots, 843$ 


\title{
Placing a Price on Pain and Suffering: A Method for Helping Juries Determine Tort Damages for Nonmonetary Injuries
}

\author{
Mark Geistfeld
}

At present, no well-defined legal standards exist for assessing tort damages for nonmonetary injuries such as pain and suffering. As a result, jury awards for pain and suffering vary widely for similar injuries. In response, many states have enacted legislative reforms that limit pain-andsuffering awards. Meanwhile, many tort-reform advocates call for eliminating pain-and-suffering damages altogether. This Article argues that pain-and-suffering awards are desirable and proposes a method for calculating nonmonetary injuries that could be implemented without resort to radical reform measures. After a thorough survey of the approaches used to compute pain-and-suffering damages and current reform proposals, the author demonstrates that full compensation is desirable since eliminating or reducing nonmonetary damage awards would create significant ineffciencies and inequities. Applying well-accepted economic principles, this Article recommends that juries assess damages from an ex ante perspective that asks how much a reasonable person would have paid to eliminate the risk that caused the pain-and-suffering injury. The author shows that this methodology is appropriate for all tort cases; that it would yield reasonably accurate results despite data limitations; and that it can and should be implemented within the current system. For these reasons, the ex ante fullcompensation award is a dramatic improvement over the current approaches to calculating pain-and-suffering damages.

\section{INTRODUCTION}

Thoughtful jurists and legal scholars have for some time raised serious questions as to the wisdom of awarding damages for pain and suffering im any negligence case, noting, inter alia, the inherent difficulties in placing a monetary value on such losses, the fact that money damages are at best only imperfect compensation for such imtangible injuries and that such damages are generally passed on to, and borne by, innocent consumers. ${ }^{1}$

1. Fein v. Permanente Medical Group, 695 P.2d 665, 680-81 (Cal.), appeal dismissed, 474 U.S. 892 (1985). 
This passage by the California Supreme Court captures many of the reasons nonmonetary injuries such as pain and suffering have long presented particularly knotty problems for the tort system. If the parties are in a contractual relationship, monetary awards for pain and suffering may not be desirable (because "innocent consumers" ultimately pay for such damages). And even for those cases in which pain-and-suffering damages appear to be desirable - for example, when the parties are not in a contractual relationship - there remains the seemingly intractable problem of how such damages should be calculated. At present, there is no test to objectively assess the severity of a plaintiff's pain-and-suffering mjury, nor is there a satisfactory method for translating this harm into the appropriate monetary award. ${ }^{2}$

The absence of well-defined standards for determiming tort damages for nonmonetary injuries largely explains why such damages have been and continue to be a focal point in the debate over tort reform. ${ }^{3}$ For exainple, the Umited States Department of Justice Tort Policy Working Group recoininended in 1986 that caps be placed on pam-and-suffering awards because they are subjective, unpredictable, and substantial. ${ }^{4}$ These same concerns led a large number of states to enact legislative reforms in the 1980s to limit paim-and-suffering awards. ${ }^{5}$ The most striking example of how the openended nature of pain-and-suffering damages motivates reforın is provided by the tort-reforin bill passed by the United States House of Representatives

2. See infra notes 21-22 and accompanying text.

3. See Margaret J. Radin, Compensation and Commensurability, 43 DuKE L.J. 56, 75 (1993) ("Compensation for pain and suffering becomes a focal point [in the current debate over tort reform], because it is claimed that allowing it gives jurics too much discretion to implement their sympathies with injured plaintiffs at the expense of (what the defense advocates fear that jurors perceive as) corporate deep pockets."); see also, e.g., Randall R. Bovbjerg et al., Valuing Life and Limb in Tort: Scheduling "Pain and Suffering," 83 Nw. U. L. Rev. 908, 919 (1989) ("At root, one's attitude about the liability system generally, and damage awards specifically, seems to depend a great deal on one's attitude concerning non-economic damages . . . ."); Robert MacCoun, Inside the Black Box: What Empirical Research Tells Us About Decisionmaking by Civil Juries, in VERDICT: AssessING THE CiviL JURY SYSTEM 137, 156 (Robert E. Litan ed., 1993) ("The size, equitability, and predictability of civil damage awards appear to be the most salient issues in the civil-jury debate."); Michael J. Saks, Do We Really Know Anything About the Behavior of the Tort Litigation System-And Why Not?, 140 U. PA. L. REv. 1147, 1241 (1992) ("Damage awards by juries have long been a central issue in considerations of the tort litigation system.').

4. U.S. Dep't of Justice, Report of the Tort Policy Workino Group on the Causes, Extent, and Policy Implications of the Current Crisis in Insurance Availability and AFFORDABILITY 66-69 (1986).

5. See, e.g., Moore v. Mobile Infirmary Ass'n, 592 So. 2d 156, 166-67 (Ala. 1991) (explaining legislative history of statutory cap); Joseph Sanders \& Craig Joyce, "Off to the Races": The I980s Tort Crisis and the Law Reform Process, 27 Hous. L. REv. 207, 257 (1990) (maintaining that the insurance crisis was the basis for most state tort-reform statutes); Glenn Blackmon \& Richard Zeckhauser, State Tort Reform Legislation: Assessing Our Control of Risks, in TORT LAW AND the PuBlic Interest 272, 273 (Peter H. Schuck ed., 1991) (stating that in 1986 alone, 41 states "enacted laws intended to slow the increase in insurance rates and costs."). For a summary of the tort-reform provisions adopted in 48 jurisdictions between 1985 and 1988, see Sanders \& Joyce, supra, at 218-23. 
in March $1995 .^{6}$ Title II of the bill, which caps pain-and-suffering damages in any health-care liability action and eliminates joint and several liability for noneconomic losses in all tort suits, is called "Lmitation on Speculative and Arbitrary Damage Awards."7

Reforms limiting pain-and-suffering damages have succeeded despite the lack of evidence (and, more fundamentally, the lack of objective standards) establishing that such awards tend to be excessively high. ${ }^{8}$ To be sure, there is evidence that supports the need for soine type of reform. Studies have shown that jury awards for pain and suffering vary widely for injuries that appear to be equally severe. ${ }^{9}$ This lack of uniformity introduces an eleinent of unpredictability into the tort systein, thereby increasing litigation and insurance expenses while undermining the principle of fairness that like parties be treated alike. The problem is particularly troublesolne given the significance of these awards. At present, pain-andsuffering damages account for about half of the total tort damages paid in products liability and medical inalpractice cases. ${ }^{10}$

Many tort-reform advocates accordingly focus on the need to minimize the undesirable variability in pain-and-suffering awards. ${ }^{11}$ The reform debate, however, also addresses the more fundamental question raised earlier: whether pain-and-suffering awards should be eliminated for cases in which the plaintiff and defendant are in a contractual relationship. Under plausible assuniptions about how the injury alters the buyer/viction's utility function, economic theory shows that even an award of zero damages for pain and suffering provides more compensation than would be preferred by the viction prior to injury. ${ }^{12}$ The reason is that the victim, like other buyers of the product or service, pays for the insurance provided by tort awards in the form of higher prices. Because tort awards for pain-and-suffering inju-

6. See H.R. 956, 104th Cong., 1st Sess. (1995).

7. Id. at Title II, $\S \S 202,203$.

8. Compare Neil Vidmar, Empirical Evidence on the Deep Pockets Hypothesis: Jury Awards for Pain and Suffering in Medical Malpractice Cases, 43 Duke L.J. 217, 263 (1993) ("It is intriguing to question why belief in the ... excessiveness of non-economic damages [is] so widespread and why many authors and policymakers have failed to recognize the flimsy or contrary evidence ....") with $\mathrm{W}$. KIP VISCUSI, REFORMING PRoducts LIABILITY 100 (1991) ("[T]he absence of any well-defined criteria for setting compensation levels has led many observers to speculate that there has been an cscalation of pain and suffering awards.").

9. See infra notes $38-42$ and accompanying text.

10. 2 American Law Institute, Reforters' Study, ENTERPRise Responsibility for Personal InJURY: Approaches to Legal and InSTTuUtional Change 201 (1991) (hereinafter "ALI StudY"). But see Vidmar, supra note 8, at 235-37 n.84 (concluding that "all of the published empirical studies of pain and suffering awards should be viewed with great suspicion as to their reliability, validity, and meaning").

11. See infra notes 66-74 and accompanying text (describing reforms designed to reduce variability in pain-and-suffering awards).

12. See Philip J. Cook \& Daniel A. Graham, The Demand for Insurance and Protection: The Case of Irreplaceable Commodities, 91 Q. J. EcoN. 143 (1977) (providing a formal economic analysis which shows why rational risk-averse individuals may not want to "fully insure an irreplaceable commodity"). This argument is spelled out in greater detail infra Part III.C. 
ries appear to be an inefficient form of insurance, a number of scholars have advocated the elimination of tort dainages for pain and suffering in products liability and medical malpractice actions. ${ }^{13}$

Thus far, those who use this insurance analysis to justify the elimination of pain-and-suffering dainages have focused on cases in which the parties are in a contractual relationship. ${ }^{14}$ However, as shown below, the logic of this critique extends to many cases in which the parties are not in a contractual relationship. ${ }^{15}$ Hence, a strong efficiency case can be made for ehminating pain-and-suffering damages for all tort cases.

Allowing tort damages for nonmonetary injuries thus raises two difficult issues: whether such awards are desirable (the "desirability problem"), and if so, whether they can be determined in a defensible inanner (the "measurability problein"). This Article addresses both of these problems and argues that they can be adequately resolved without resort to radical reform ineasures.

With respect to the desirability problem, I show that the insurance analysis which yields the conclusion that pain-and-suffering damages are inefficient depends upon unrealistic assumptions. By altermg the analysis to reflect more realistic assumptions, I show that consumers probably prefer full compensation for those pain-and-suffering injuries presently compensable in tort.

Having justified the full compensation of these pain-and-suffering injuries, I then address the measurability problem. Resolving this problem is critical, as some scholars have recognized, because even if tort awards for pain and suffering are desirable in principle, they may be undesirable in practice if there is no defensible inethod for calculating the appropriate award. ${ }^{16}$ The problem is that there is no obvious relationship between

13. See, e.g., John E. Calfee \& Paul H. Rubin, Some Implications of Damage Payments for Nonpecuniary Losses, 21 J. Legal Stud. 371 (1992); Jules L. Coleman, Risks and Wrongs 420-29 (1992); Alan Schwartz, Proposals for Products Liability Reform: A Theoretical Synthesis, 97 YALE L.J. 353, 411 (1988); see also VIScuSI, supra note 8, at 114-16 (suggesting that pain-and-suffering awards be based on insurance values, which are typically zero except for minor injuries, and that deterrenee be achieved through punitive damages).

14. See Calfee \& Rubin, supra note 13, at 404 (" [I]t is important [for future research] to determine the effects of the excess payment for nonpecuniary losses in a system of torts involving parties without contractual relationships.").

15. A formal analysis of this point is contained infra app. $\S 6$. The intuition behind this conclusion is explained infra notes $188-192$ and accompanying text.

16. The classic exposition of this position is Louis L. Jaffe, Damages for Personal Injury: The Impact of Insurance, LAw \& CONTEMP. PROBS., Winter 1953, at 219, 224-25 (arguing that pain and suffering is an injury, but allowing monetary awards as compensation is not defensible because it requires the evaluation of the "imponderable" by a method of "arbitrary indeterminateness"). Due to the difficulty of measuring pain-and-suffcring damages, some scholars have proposcd that such measurement should be attempted only in the most egregious cases. See, e.g., Stanley lngber, Rethinking Intangible Injuries: A Focus on Remedy, 73 CALIF. L. Ruv. 772, 809 (1985) (proposing full compensation for noneconomic losses only in cases of intentional wrongdoing); Warren A. Seavey, Torts and Atoms, 46 CALIF. L. REv. 3, 11-12 (1958) (proposing that pain-and-suffering damages be limited to cases involving conscious wrongdoing and wrongful acts). 
money and a nonmonetary imjury. Consequently, different ways of conceptualizing low these damages sliould be determined could yield significantly different damages awards. This point is dramatically illustrated by a recent study that shows the way in which jury instructions are worded will have a substantial impact on the amount of "full coinpensation" that imdividuals (that is, potential jurors) would award for a given pain-and-suffering injury, with some instructions yielding a fully compensatory pain-and-suffering award twice as great as the amount yielded by other instructions. ${ }^{17}$ This study helps to explain why pam-and-suffering awards presently exhibit so mucl variability, as jury instructions are currently so open-ended that jurors are likely to use a number of different inetlods to determine awards.

Resolving the measurability problein is necessary, then, if we are to reduce the variability in these damages awards. However, because the choice of a particular method for determining pain-and-suffering damages is likely to have a significant impact upon award levels, it is necessary to slow that any given method for calculating these damages provides an appropriate measure of full coinpensation. The resolution of the measurability problem thus depends upon low we resolve the desirability problem.

I maintain that the inethod for determining fully compensatory dainages that is most defensible in principle also provides reasonably welldefined criteria that jurors can use to determine the appropriate monetary award. This method defines "full compensation" by reference to an ex ante perspective and seeks to ascertain how the plaintiff would liave measured the cost of the pain-and-suffering injury wlien sle faced the risk that caused the injury. The "ex ante full-coinpensation award" yielded by this method is desirable in principle and consistent witl current law. Nevertheless, this damages ineasure could be rejected if it raises serious practical problems. It is thus necessary to coinpare the inethod used to derive the $e x$ ante fullcoinpensation award with the method provided by current law and other proposed reforins. On balance, I conclude that the $e x$ ante fullcompensation award is the most promising in principle and in practice.

Part I sets out the approach currently used by the courts for instructing juries on low to compute pain-and-suffering damages. Part II describes the probleins that arise under the current approacli. Part III then surveys and assesses the various types of reforins that liave been proposed to reinedy the probiems with the current system. I show that the various reforin proposals fail to resolve adequately either the desirability problem or the ineasurability problein.

Part IV addresses the desirability problein and shows why it is problematic to conclude that it is inefficient at present for the tort systein to provide full compensation for nonmonetary injuries. Part V then addresses the measurability problein for torts involving contractual relationships and

17. See Edward J. McCaffery et al., Framing the Jury: Cognitive Perspectives on Pain and Suffering Awards, 81 VA. L. REV. (forthcoming 1995). 
shows that the ex ante full-compensation award provides a damages measure that would fully compensate the plaintiff. The damages calculation, which is based on well-accepted economic principles, requires that the jury determine what a reasonable person would pay to eliminate the risk of suffering an injury equal to the severity of the plaintiff's pain-and-suffering imjury. ${ }^{18}$ Part V shows that this damages measure is consistent with current case law and tort principles regarding pain-and-suffering damages and would yield defensible results in a wide range of cases despite data limitations. Part VI addresses the measurability problem for torts involving noncontractual relationships. It shows that although the $e x$ ante fullcompensation award can be derived from the amount that a reasonable person would have accepted in exchange for facing the risk of incurring a painand-suffering injury, the more desirable approach is to base the award upon a reasonable person's willingness to pay to eliminate that risk.

Part VII reconsiders current practices and other reform proposals in light of the ex ante full-compensation award. I conclude that the jury determination of the ex ante full-compensation award is the most defensible. The problein with pain-and-suffering damages therefore stems from the lack of guidance that the law currently provides jurors in this regard. Meaningful guidance on how these damages should be determined would greatly diminish the flaw of the tort system in the way it awards monetary damages for pain and suffering.

\footnotetext{
18. The economic approach to valuing health based on how much society is willing to pay is usually traced back to a 1968 article by Schelling . . . and to Mishan (1971). It is almost surprising how widely accepted the approach has become in the years following these essays. The approach was well-received by economists beeause it was the natural extension of the methodology of applied welfare economics to the area of health. The willingness to pay approach is increasingly gaining acceptance in policy circles.
}

George Tolley et al., Overview, in Valunng Health for Policy: An Economic Approach 4 (George Tolley et al. eds., 1994).

Because this methodology has become conventional within cconomics, it is not surprising that a number of others havc observed that it could be used to determine pain-and-suffering damages in tort cases. See, e.g., Jennifer Arlen, Note, An Economic Analysis of Tort Damages for Wrongful Death, 60 N.Y.U. L. REv. 1113, 1121-34 (1985); Lloyd Cohen, Toward an Economic Theory of the Measurement of Damages in a Wrongful Death Action, 34 EMORY L.J. 295 (1985); David W. Leebron, Final Moments: Damages for Pain and Suffering Prior to Death, 64 N.Y.U. L. REv. 256, 274-78 (1989); William M. Landes \& Richard A. Posner, The Economic Structure of Tort Law 187-89 (1987); Ted R. Miller, Willingness to Pay Comes of Age: Will the System Survive?, 83 Nw. U. L. Rev. 876 (1989); RICHARD A. POSNer, ECONOMIC ANALYsIS OF LAw 199 (4th ed. 1992). Hence, the concepts underlying the damages calculation proposed in this Article have already in some scnse become part of torts scholarship. Recognizing the usefulness of the methodology is only a first step, however. As this Article will show, there are a number of difficult issues that must be addressed, such as why this methodology is appropriate for all tort cases; how it can be applied; and whether it can and should be implemented within the current system. 


\section{The Current System}

Pain-and-suffering damages in personal injury cases typically encompass compensable damages that need not be specifically pleaded by the plaintiff. ${ }^{19}$ In effect, then, "pain and suffering" serves as a category of damages including not only physical pain, but also a wide range of intangible injuries such as fright, nervousness, grief, anxiety, and indignity. ${ }^{20}$ Common to the various types of mjuries that are characterized as "pain and suffering" is that they are all purely nonpecuniary losses.

The difficulty created by pain-and-suffering damages is that there is no obvious way to translate an intangible, nonmonetary injury into a monetary award. Moreover, there is no objective test that measures the severity of the victim's pain-and-suffering mjury. ${ }^{21}$ As a result, courts have tended to avoid the use of well-defined guidelines that can aid jurors in their deterinination of the award. ${ }^{22}$ Instead, as imdicated by the following standard jury charge, jurors are given only vague instructions on how to evaluate the evidence after being told that there is no good way to determine an appropriate monetary award:

In assessing damages, ... the law allows you to award to plaintiff a sum that will reasonably compensate him for any past physical pain, as well as pain that is reasonably certain to be suffered in the future as a result of the defendant's wrongdoing.

There are no objective guidelines by which you can ineasure the money equivalent of this element of injury; the only real measur-

19. See 4 FOWLER V. HARPER ET AL., THE LAW OF TORTS $\$ 25.5$, at 520-26 (2d ed. 1986). Because pain-and-suffering damages need not be specifically pleaded, they are called "general damages." Id. By contrast, "special damages" comprise losses that must be specifically pleaded and typically encompass pecuniary losses. Id. at 526 ("Loss of value of injured property is general damage, but in all other cases it is fairly safe to generalize by calling pecuniary loss special damage.") (footnote omitted).

20. See 22 Am. Jur. 2D Damages $\$$ 239-240 (1988).

21. There are medical diagnostic tests that "can be helpful in supporting or denying the existence of pain and determining whether the patient is capable of experiencing pain in the first instance. Nevertheless, the experience of pain is always subjective because pain is based, in part, upon one's conscious perception of a stimulus." Daniel J. Gabler, Comment, Conscious Pain and Suffering Is Not a Matter of Degree, 74 MARQ. L. REv. 289, 307 (1991) (footnotes omitted); see also Leebron, supra note 18, at 263-65 (showing how the various elements of pain and suffering are "extraordinarily subjective and fact dependent'); Richard H. Spector, Pain and Suffering: Current Concepts, 34 MED. TRIAL TECH. Q. 202, 223 (1987) ("There is no specific or diagnostic test for pain. . . . There is no specific or diagnostic test that can produce a 'picture' of pain.').

22. See Botta v. Brunner, 138 A.2d 713, 718 (N.J. 1958) ("For hundreds of years, the measure of damages for pain and suffering following in the wake of a personal injury has been 'fair and reasonable compensation.' This general standard was adopted because of universal acknowledgment that a more specific or definitive one is impossible.'); Leebron, supra note 18, at 265 ("The response of the legal system to the doctrinal and factual complexity of pain and suffering has been to make the awarding of this element of damages procedurally simple but analytically impenetrable. The law provides no guidance, in terms of any benchmark, standard figure, or method of analysis, to aid the jury in the process of determining an appropriate award."). 
ing stick, if it can be so described, is your collective enlightened conscience. You should consider all the evidence bearing on the nature of the injuries, the certainty of future pain, the severity and the likely duration thereof. ${ }^{23}$

Although jurors are not ordinarily told how they should translate their evaluation of injury severity into a inonetary award, there are two notable exceptions. First, inost jurisdictions allow jurors to calculate the pain-andsuffering award based on the "per diem" method whereby the jury determines the dainages for the intangible injury as it relates to a specific unit of time (such as a day), and the total award is then determined by multiplying the damages per unit (such as $\$ 10$ per day) by the total nuniber of time units (days) during which the plaintiff was injured and will continue to be imjured. ${ }^{24}$ The per diein method, however, does not provide any guidelines that might help the jury determine the appropriate ainount of dainages per unit of time. Instead, the typical unit-of-time arguinent contemplates that an arbitrary figure for pain and suffering will be applied to the unit of time under consideration. ${ }^{25} \mathrm{~A}$ nuniber of courts have consequently rejccted the per diem inethod, because by lending a quantitative coinponcnt to the dainages calculation, it "lend[s] a false air of certainty to an area where none exists."26

Another inethod that has been used to help jurors translate their evaluation of injury severity into a monetary award relies upon willinguess-topay ineasures to calculate the loss of life's pleasure, or what is commonly called "hedonic dainages," in wrongful death cases. ${ }^{27}$ Like the per diein inethod, the courts have been split over whether this method is appropriate. ${ }^{28}$ This willingness-to-pay approach will be discussed in greater detail below. ${ }^{29}$ For present purposes, it is sufficient to note that loss of life's pleasure is only one coinponent of pain and suffering (or a different eleinent

23. Graham Douthwatre, Jury Instructions on Damages in Tort Actions § 6-17, at 274 (2d ed. 1988); see also, e.g., Committee on PATtern Jury Instructions, Fifth Circuit, Pattern JuRy INSTRuctions (Crvil CASES) $\$ 15.4$ (1994) [hereinafter FifTH Circuit Pattern JuRY INSTRUCTIONS] ("There is no exact standard for fixing the compensation to be awarded for these elements of damage. Any award that you make should be fair in the light of the evidence."); MODERN Federal Jury Instructions, Civil: Eleventh Circuit Pattern Jury Instructions $\$ 2.1$ (1993) [hereinafter Eleventh Circuit PATtern JURY INSTRuctions] ("There is no exaet standard for fixing the compensation to be awarded on account of such elements of damage. Any such award should be fair and just in the light of the evidence.").

24. See generally James O. Pearson, Jr., Annotation, Per Diem or Similar Mathematical Basis for Fixing Damages for Pain and Suffering, 3 A.L.R.4rH 940 (1981).

25. See, e.g., Combined Ins. Co. of Am. v. Sinclair, 584 P.2d 1034, 1050 (Wyo. 1978).

26. Pearson, supra note 24 , at 945 .

27. "As interpreted by the courts around the United States, hedonic damages means either a loss of enjoyment of life or loss of life's pleasures." Douglas L. Price, Hedonic Damages: To Value a Life or Not to Value a Life?, 95 W. VA. L. REv. 1055, 1056 (1993) (footnote omitted). For a description of this approach, see Miller, supra note 18.

28. See Tina M. Tabacchi, Note, Hedonic Damages: A New Trend in Compensation?, 52 OHo ST. L.J. 331, 342-48 (1991).

29. See infra Part VII.B. 
of damages in some jurisdictions) ${ }^{30}$ and provides a measure only of the average cost of injury rather than a damages measure for a particular plaintiff's injury. ${ }^{31}$ Thus, except for the limited use of willimgness-to-pay measures in wrongful death cases, jurors have no inethodology to quantify painand-suffering damages.

The lack of objective standards for assessing pain-and-suffering awards also plagues the judicial review of jury awards. A reviewing court can overturn the jury award only if it shocks the conscience. ${ }^{32}$ In overturning the award, the court should provide an amount "a reasonable person would estimate as fair compensation." $" 33$ Of course, the reviewing court could compare the award before it to awards given in similar cases, but courts rarely do so. ${ }^{34}$ Hence, judges also lack a method for translating injury severity into the appropriate nonetary award.

\section{II}

\section{Problems Created by the Current System}

\section{A. Arbitrariness in Awards for Pain and Suffering}

Because jurors are given little guidance on how to determine pain-andsuffering damages, the process leading to these awards provides a variety of reasons for concern. At minimum, a large eleinent of arbitrariness likely exists in any award because jurors are unsure of how to derive the award.

In civil cases, jurors report that determining damages is more diffcult for them than is deciding on liability. They find the guidance that is given to thein on how to compute damages to be minimal and agree with legal analysts that the law itself provides precious little guidance for assessing damages. ${ }^{35}$

For example, one jury-simulation exercise involving 147 venirenien waiting to be called for jury selection in North Carolina found that:

30. See Kyle R. Crowe, Note, The Semantical Bifurcation of Noneconomic Loss: Should Hedonic Damage Be Recognized Independently of Pain and Suffering Damage?, 75 Iowa L. Rev. 1275, 1277 (1990) (stating that the majority of states treat hedonic damage as a separate damage element whereas others treat it as only one aspect of pain and suffering and still others do not recognize hedonic Ioss as compensable damage).

31. See Miller, supra note 18, at 879 (explaining that willingness-to-pay measures "are normally aggregated across individuals to obtain the value per anonymous or statistical life saved"). For an analysis of the difficulties raised by trying to match individual preferences to the aggregative measures derived by willingness-to-pay or willingness-to-accept studies, see Lewis $\mathrm{A}$. Komhauser, The Value of Life, 38 CLev. ST. L. Rev. 209 (1990); Miller, supra note 18, at 899-900.

32. See, e.g., Bethke v. Duwe, 41 N.W.2d 277, 280 (Wis. 1950) ("[D]ifferent individuals will vary in their estimate of the sum which will be a just pecuniary compensation. Hence, all that the court can do is to see that the jury approximates a sane estimate, or, as it is sometimes said, see that the results attained do not shock the judicial conscience.").

33. REsTATEMENT (SECOND) OF TORTS $\S 912 \mathrm{cmt} . \mathrm{b}$ (1979).

34. Leebron, supra note 18, at 266.

35. Shari S. Diamond, What Jurors Think: Expectations and Reactions of Citizens Who Serve as Jurors, in VERDICT, supra note 3, at 282, 297. 
[Jurors uniformly commented on the difficulty of putting a price on pain and suffering and used different methods of calculating the awards. Some roughly split the difference between the defendant's and the plaintiff's suggested figures. One juror doubled what the defendant said was fair, and another said it should be three times medical expenses. ... A nuniber of jurors assessed pain and suffering on a per month basis .... Other jurors indicated that they just came up with a figure that they thought was fair. ${ }^{36}$

Another study interviewed jurors who in 1984 decided a products liability case in Texas. These jurors used a process of "guesstimation" to determine pain-and-suffering damages. ${ }^{37}$

Although the open-ended nature of the damages calculation leads to some arbitrariness in the calculation of pain-and-suffering awards, the awards are not completely arbitrary. One empirical study, for exainple, found that "[p]ain and suffermg compensation is not randoin ... it [varies] systematically with a variety of injury types in the expected manner." ${ }^{38}$ This finding is supported by a number of other empirical studies that show the severity of injury is a good predictor of the size of a pain-and-suffering award. ${ }^{39}$

However, even though plaintiffs who suffer more severe injuries tend to receive higher awards (indicating some degree of "vertical equity"), those with similar pain-and-suffering injuries are often awarded significantly different amounts of damages (indicating a lack of "horizontal equity"). ${ }^{40}$ The system currently achieves some degree of vertical equity but fails to achieve horizontal equity because jurors are told to consider the severity of injury in calculating the award but are then given no guidance on how to translate injury severity into an appropriate inonetary amount. ${ }^{41}$ Under such instructions, any given jury is likely to do reasonably well at compensating more severe injuries with more inoney. Different juries,

36. Vidmar, supra note 8, at 254-55 (footnote omitted).

37. Edith Greene, On Juries and Damage Awards: The Process of Decisionmaking, 52 LAw \& Contemp. Probs. 225, 230 (1989).

38. W. Kip Viscusi, Pain and Suffering in Product Liability Cases: Systematic Compensation or Capricious Awards?, 8 INT'L Rev. L. \& EcoN. 203, 213 (1988) (describing study of over 10,000 products liability claims closed by 23 insurance companies between mid-1976 and mid-1977).

39. See Audrey Chin \& Mark A. Peterson, Deep Pockets, Empty Pockets: Who Wins in CoOK COUNTY JURY TRIALs 56, 57 (1985); Bovbjerg et al., supra note 3, at 908, 923 (showing that sevcrity of injury explains about $40 \%$ of variation); Frank A. Sloan \& Chee Ruey Hsieh, Variability in Medical Malpractice Payments: Is the Compensation System Fair?, 24 LAw \& Soc'Y Rev. 997, $1007-$ 08 (1990); Mark I. Taragin et al., The Influence of Standard of Care and Severity of Injury on the Resolution of Medical Malpractice Claims, 117 AnNals INTERnac Med. 780, 781 (1992).

40. For cmpirical studies that reacb this conclusion, see Bovbjerg et al., supra note 3, at 924 (" 'Vertical' equity, the faimess between separate categories of injury, is rather good. The main problem is the absence of 'horizontal' equity-the extent of variation within a single category."); Leebron, supra note 18, at 310 ("[S]imilarly injured plaintiffs who experience similar pain and endure similar suffering are often awarded vastly differing amounts of damages.").

41. See supra note 23 and accompanyiug text. 
though, are likely to use different methods to determine an award for equally severe injuries, resulting in a large degree of variation within each injury category.

Not surprisingly, then, injury severity ultimately explains only part of the awards. One study, for example, found that the severity of injury explaims forty percent of the variation in pain-and-suffering awards. ${ }^{42}$ What explains the remainder of the award? The possibility that jurors rely on extralegal factors such as gender, race, socioeconomic status, or physical appearance is a significant concern, ${ }^{43}$ particularly since studies have shown that such factors become inore influential in jury decision-making when the legal standards are the most ambiguous. ${ }^{44}$ Even if jurors are not influenced by extralegal factors, the lack of a well-defined method for calculating the award subjects it to the appearance of unfairness. ${ }^{45}$

These same concerns may also lead one to question the validity of judicial review of such awards. Absent evidence that jurors relied on extralegal factors in deriving the award, what is it that allows judges to find the award excessive, particularly since reviewing courts rarely compare verdicts across cases? As Eric Schnapper has observed, the open-ended nature of the damages determination creates a particularly problematic situation for appellate review, because "[t]he jury itself nust exercise considerable discretion in fixing the amount of the verdict; the trial judge in turn exercises broad discretion in approving or rejecting the jury's action. This double exercise of discretion seems inconsistent with virtually any direct appellate review of these verdicts." ${ }^{\text {"46 }}$ Yet, one study found that as compared to trial judges, appellate judges were three times as likely to find the damages awarded by juries to be excessive. ${ }^{47}$

42. Bovbjerg et al., supra note 3, at 923 . A different study found that injury severity accounts for $40 \%$ of the variation in total awards-not only the pain-and-suffering component-in medical malpractice cases. See Sloan \& Hsieh, supra note 39, at 1025.

43. See Oscar G. Chase, Helping Jurors Determine Pain and Suffering Awards, in CrvIL Justice REFORM IN THE 1990s (Larry Kramer ed., forthcoming 1995).

44. See, e.g., Martin F. Kaplan \& Charles E. Miller, Group Decision Making and Normative Versus Informational Influence: Effects of Type of Issue and Assigned Decision Rule, $53 \mathrm{~J}$. PersonaltTy \& Soc. Psychol. 306, 310 (1987) (describing study showing that juror discussions regarding punitive damages are more likely to involve normative, value-laden judgments than references to the evidence presented at trial). For a survey of this literature, see Frederick S. Levin, Note, Pain and Suffering Guidelines: A Cure for Damages Measurement "Anomie," 22 U. Mich. J.L. REF. 303, 321 \& nn.63-68 (1989).

45. Cf. MacCoun, supra note 3, at 156 ("The size, equitability, and predictability of civil damage awards appear to be the most satient issues in the civil-jury debate. Participants and obscrvers often find the 'black box' dilcmma especially frustrating here, and this frustration is enhanced by occasional anecdotes that suggest arbitrary or irrational behavior.") (footnote omitted).

46. Eric Schnapper, Judges Against Juries-Appellate Review of Federal Civil Jury Verdicts, 1989 Wis. L. Rev. 237, 340.

47. Leehron, supra note 18, at 308. "Typically, if it finds an award to be excessive, a reviewing court will order a remittitur of about fifty percent." Id. at 266; see also Schnapper, supra note 46, at 341 (describing study of all cases in federal courts of appeals between fall of 1984 and fall of 1985 that 


\section{B. Consequences of Arbitrary Pain-and-Suffering Damages Awards}

In addition to putting the system's integrity at issue, the element of arbitrariness and resultant unpredictability of pain-and-suffering awards undermine the deterrence function of the tort system and increase insurance costs. Tort law promotes deterrence because the prospect of tort liability gives risk-creating actors an incentive to consider whether the costs of precautions that would reduce the likelihood of imjury are less than the liability costs that the actor would incur in the absence of such precautions. For this reason, tort law can lead to efficient levels of safety measures when the legal standards are applied with certainty and accuracy in each case. ${ }^{48}$ But when the tort system imposes liability costs in an unpredictable inanner, it becoines difficult for risk-creating actors to determine whether the costs of prevention are less than the benefits of accident reduction. This uncertainty inay lead to overdeterrence or underdeterrence, ${ }^{49}$ both of which have undesirable consequences.

Overdeterrence, for example, may take the form of the actor withdrawing from the activity coinpletely, ${ }^{50}$ such as inanufacturers ceasing production of vaccines. ${ }^{51}$ Perhaps such a withdrawal from the market is desirable because the social costs of the vaccine exceed its benefits. But when liability costs are uncertain, the prospect of unwarranted liability may induce manufacturers to cease producing the vaccine even though its social benefits exceed the social costs. For this reason, when liability costs are unpredictable, we can no longer be confident that the tort system promotes efficient levels of safety and deterrence. Indeed, the notion that unpredictable tort liability costs were preventing socially beneficial product innovations provided the impetus for the Bush administration to make products liability reform a "top priority" in $1990 .{ }^{52}$

There are other reasons to suspect that the tort systein is unable to achieve efficient levels of deterrence due to the legal uncertainty engendered by pain-and-suffering awards. Since inost tort cases are settled, ${ }^{53}$ the

found "[i]n most instances in which the appellate courts fixed the amount of the remittitur, the verdict deemed appropriate by the appellate panel was at least half the size of the original verdict."').

48. See Steven Shavel, Economic Analysis of Accident Law 5-46 (1987).

49. See generally Richard Craswell \& John E. Calfee, Deterrence and Uncertain Legal Standards, 2 J.L. Econ. \& Organization 279 (1986).

50. For one such example, see Viscust, supra note 8, at 87-88 (stating that Coca Cola abandoned a promotional campaign in which it had invested over $\$ 100$ million due to potential liability for pain and suffering even though the pain-and-suffering costs that any individual would likely incur appeared to be insignificant).

51. For an analysis of the effect of liability rules on the market for childhood vaccines, see Richard L. Manning, Changing Rules in Tort Law and the Market for Childhood Vaccines, 37 J.L. \& ECON. 247 (1994).

52. See Dan Quayle, Now Is the Time for Product Liability Reform, Prod. SAFETY \& LIAB. REP. (BNA) Mar. 20, 1990, at 306.

53. 1 David M. Trubek et al., Crvil Limgation Research Project: Final Report S-23 (1983) (reporting study of all types of civil hitigation showing that only $8 \%$ of filings went to trial, with over $50 \%$ of the cases being settled by voluntary agreement of the parties). 
way in which tort rules affect behavior will depend in large part on how parties bargain in the "shadow of the law." It is a common settlement practice to coinpute pain-and-suffering damages to be computed as some multiple of the out-of-pocket medical and related financial expenses incurred by the plaintiff. ${ }^{5 s}$ As there is no reason why actual pain-andsuffering injuries should be related to some multiple of the plaintiff's economic loss, ${ }^{56}$ the practice appears to be a bargaining convention that is acceptable to all parties concerned because it amehorates the uncertainty that each party would face if a jury were to determine the award. ${ }^{57}$ But this settlement practice inplies that the liability costs incurred by defendants ordinarily will not reflect the actual cost of the pain-and-suffering injury. Hence, potential tortfeasors are unlikely to take the actual cost of injury into account when determining how much precaution to take. This distortion of the cost-benefit calculus in turn may lead to either overdeterrence or underdeterrence, depending on whether the settlement amounts are over or under the actual amount of injury. In addition, calculating the pain-andsuffering damages as some multiple of economic loss creates further inefficiencies, because it "also promotes bill-padding which, by inflating economic accident costs, can raise proportionate compensation for intangible mjury.".58

To be sure, individuals and enterprises can protect themselves from the vagaries of tort liability by purchasing liability insurance, but the legal uncertainty created by pain-and-suffering awards makes it unlikely that insurance premiums can be priced in a manner that provides policyholders with an incentive to take efficient safety precautions. A policyholder has an incentive to take such precautions when the ainount of her premium is sensitive to changes in the expected cost of the covered losses caused by her activities ("experience rating"). ${ }^{59}$ Due to the significant arbitrary compo-

54. See Robert H. Mnookin \& Lewis Kornhauser, Bargaining in the Shadow of the Law: The Case of Divorce, 88 Y ALE L.J. 950 (1979).

55. See H. Laurence Ross, Settled Out of Court: The Soctal Process of Insurance ClaIMS ADJUSTMENTS 107-08 (1970) (stating that multiple is an "arbitrary coefficient-typically from two to five, depending on the practice of the area"); JEFrREY O'CONNELr, ENDING $1_{\text {NSULT TO INJURY: }}$ No-Faurt InsUrance fOR Products AND Services 51 (1975) (stating that multiple is between two and ten); Neil Vidmar \& Jeffrey J. Rice, Assessments of Noneconomic Damage Awards in Medical Negligence: A Comparison of Jurors with Legal Professionals, 78 IowA L. REv. 883, 894 (1993) ("Judges and attomeys in North Carolina frequently speak of an informal guideline that suggests that noneconomic damages should be between three and seven times the amount of economic damages.").

56. The reason is that "all pain is now understood to be a mental event having biological, psychological and social determinants." Spector, supra note 21, at 223.

57. See, e.g., Ingber, supra note 16, at 779 ("[T] avoid the risk and uncertainty of a jury verdict, ... defendants often settle claims for noneconomic loss by offering a fixed multiple of more easily provable economic loss, for example, medical expenses.').

58. Id.; see also Peter Passell, The Health Care Plan Could Worsen Injury-Claim Abuses, N.Y. TMMES, Oct. 14, 1993, at D2 (arguing that universal health care may lead to an increase in pain-andsuffering awards by making it easy for plaintiffs to pad their medical bills).

59. Assume that the policyholder can adopt a safety measure that costs her $\$ 10$ and will reduce losses that are covered under the policy. The policyholder has an incentive to adopt this measure and 
nent of pain-and-suffering damages, it may not be sound actuarial practice for insurers to attribute the entire amount of such damages to the conduct of the defendant policyholder. To the extent that losses are unpredictable or arbitrary, msurers treat the resultant "risk ambiguity" as an additional cost to be added to the expected value of the loss plus administrative expenses. ${ }^{60}$ Thus, of the costs that comprise a policyholder's premium, the expccted value of the loss is the only one that depends upon the policyholder's conduct. $^{61}$ The arbitrary component of pain-and-suffering dainages therefore cannot be experience rated. Moreover, the expected value of loss is unlikely to equal the actual cost of the pain-and-suffering injuries caused by a policyholder's conduct, since the insurer calculates the expected loss on the basis of the liability payments it expects to inake under the policy. As described above, prevailing settlement practices indicate that these liability payments are unlikely to equal the actual pain-and-suffering injuries caused by the policyholder. This inakes it even inore bikely that the premiuns paid by a policyholder do not reflect the actual cost of the injuries caused by her activities.

The legal uncertainty arising from unpredictable pain-and-suffering awards has other adverse economic consequences. The additional cost created by risk ambiguity increases the price of liability insurance and, in some instances, causes insurers to withdraw such coverage froin the market. ${ }^{62}$ As a result, individuals or enterprises might forgo activities in which they would otherwise engage if they were able to obtain lower-priced liability

incur the $\$ 10$ expense if by doing so her liability insurance premiums are reduced by more than $\$ 10$. Thus, the practice of "experience rating"-the raising or lowering of premiums to refleet changes in the number and amount of claims expected to be paid over the life of the policy-gives policyholders an incentive to adopt efficient safety measures. See KenNeth S. ABraHaM, Distrubuting Risk: Insurance, Legal Theory, and Public Policy 45-46 (1986).

60. See Howard Kunreuther \& Robin M. Hogarth, How Does Ambiguity Affect Insurance Decisions?, in Contributions to InSURANCE Economics 307, 321 (Georges Dionne ed., I992) ("A principal conclusion emerging from surveys of actuaries and underwriters is that they will add an ambiguity premium in pricing a given risk whenever there is uncertainty regarding either the probability or losses." ).

61. It is possible that the policyholder could act in a manner that completely eliminates the risk of tort liability. But if this option were available and desirable to the policyholder, then she would not need to purchase liability insurance.

62. "[O]pen-ended" jury determinations of damage awards for pain and suffering is a "key source" of uncertainty that appears to "aggravate the problem of unaffordable (or unavailable) insuranee coverage" because

[e]x ante, the prospect of a runaway tort award-even worse, of a multiplicity of such awards stemming from a single decision about a product design or plant location-can generate a level of risk aversion among potential defendants and their insurers that is far more costly and economically disruptive than the same tort expenditures made in a more rational and predictable fashion.

Kenneth S. Abraham et al., Enterprise Responsibility for Personal Injury: Further Reflections, 30 SAN Drego L. Rev. 333, 338-39 (1993); see also Bovbjerg et al., supra note 3, at $926 \mathrm{n} .98$ ("Because there is literally no upper bound to damage awards, reinsurers are extremely concerned about participating to the high levels sought by primary insurers and their insureds, and insurance markets may contract, for the capital necessary to underwrite primary companies assuming the risk is simply not present."). 
insurance in an environment without this legal uncertainty. ${ }^{63}$ This is not a hypothetical concern, as it provided a major impetus for the tort reforms enacted by the states in the $1980 \mathrm{~s}^{64}$ and for the tort-reform bill passed by the United States House of Representatives in March, 1995.65

\section{III}

\section{Analysis of Reform Proposals}

The range of problems caused by the current approach for determining pain-and-suffering tort awards has led a number of states to place limits on pain-and-suffering damages and has engendered a variety of proposals for further reforms. Although there are inerits to each of the reforms, none of them provides a satisfactory method for translating an imdividual's painand-suffering injury into the appropriate monetary award.

\section{A. Caps or Ceilings}

One of the more politically successful and long-standing proposals for reforming pain-and-suffermg damages is to place a cap or ceiling on the amount a plaintiff can recover for pain-and-suffering damages. ${ }^{66} \mathrm{~A}$ number of states have enacted legislation that limits tort awards in this manner; ${ }^{67}$

63. We cannot determine whether these outcomes are desirable if liability insurance premiums do not reasonably reflect the social cost of the injuries caused by the policyholder. For example, a business may be paying liability premiums that substantially understate (or overstate) the actual costs of the injuries caused by this business' activities. An increase in premiums that drives this business out of operation therefore may be socially desirable (or undesirable).

64. See supra note 5 and accompanying text.

65. See supra note 6 , at $\S 2(5)$ (one of the findings and purposes of the bill is that "as a result of excessive, unpredictable, and often arbitrary damage awards ... . consumers have been adversely affected through the withdrawal of products, producers, services, and service providcrs from the national market, and from excessive liability costs passed on to them through highcr prices.").

66. For an early example of a reform proposal of this type, see Marcus L. Plant, Damages for Pain and Suffering, 19 Orno ST. L.J. 200, 210-11 (1958) (suggesting that pain-and-suffering damages should be capped at $50 \%$ of plaintiff's proven medical, nursing, and hospital expenses).

67. See, e.g., AlASKa STAT. $\$ 09.17 .010$ (Supp. 1993) (limiting noneconomic damages in civil actions to $\$ 500,000$ for each claim based on a separate incident or injury, except in cases of disfigurement or severe physical impairment); CAL. Crv. CODE $\$ 3333.2$ (West Supp. 1994) (limiting noneconomic damages for medical malpractice actions to \$250,000); CoLO. REv. STAT. ANN. \$ 13-21102.5 (West $1989 \&$ Supp. 1994) (limiting damages for noneconomic injury in civil actions to $\$ 250,000$, or to $\$ 500,000$ if the court finds justification for the larger award by "clear and convincing evidence"); KaN. Stat. ANN. $\$ 60-19 a 02$ (Supp. 1993) (limiting noneconomic damages for personal injuries to $\$ 250,000)$; MD. CODE ANN., CTS. \& Jud. Proc. \$ 11-108 (1989 \& Supp. 1993) (limiting noneconomic damages in all personal injury actions to $\$ 350,000$ ); MAss. GEN. LAws ANN. ch. $231, \S 60 \mathrm{H}$ (West Supp. 1994) (limiting noneconomic damages in medical malpractice actions to $\$ 500,000$ per incident absent a finding of "a substantial or permanent loss or impairment of a bodily function or substantial disfigurement, or other special circumstances"); Mrch. CoMP. LAws ANN. $§ 600.1483$ (West Supp. 1994) (limiting noneconomic damages in medical malpractice actions to $\$ 280,000$ except in cases of permanent paralysis, permanently impaired cognitive capacity, or permanent infertility, for which the limit is \$500,000); Mo. ANN. Stat. $\$ 538.210$ (Vernon 1988 \& Supp. 1994) (limiting noneconomic damages in actious against health care providers to $\$ 350,000$ per defendant per occurrence); W. VA. CODE $\$ 55-7 \mathrm{~B}-8$ (1994) (limiting noneconomic damages to $\$ 1,000,000$ in medical malpractice cases); WIS. Stat. ANN. $\$ 893.55$ (4) (West 1983 \& Supp. 1994) (limiting noneconomic damages in medical 
the Canadian Supreme Court has also chosen to impose a ceiling on all awards for pain and suffering. ${ }^{68}$

Caps or ceilings are a response to the current system's failure to provide jurors with a method for determining pain-and-suffering damages, as that failure gives the impression that such damages know no limit. ${ }^{69} \mathrm{By}$ placing an easily determined upper bound on a defendant's liability in a given case, caps or ceilings reduce legal uncertainty and therefore lielp to decrease the cost of liability insurance. The reform also reduces liability insurance costs insofar as the caps or ceilings limit the growth of the general level of tort awards for pain and suffering.

Capping damages is problematic because it fails to address the fundamental probleins created by the current systein for awarding pain-andsuffering damages. This reform does not help juries or courts determine the appropriate award in the first instance, and thus any awards below the cap are subject to the same clamis of arbitrariness and unfairness that plague the current systein. Indeed, caps or ceilings actually introduce a new element of unfairness into the system because studies show that caps do not affect all tort cases equally, but rather have a targeted effect on the most severe injuries. ${ }^{70}$ If the most severe injuries tended to involve the most excessive awards, then there would be a degree of vertical inequity in the current system that might justify caps. The data, lowever, show that the most severe injuries involve inadequate ratlier than excessive damages awards. ${ }^{71}$ Caps therefore have the effect of placing the entire burden of reforn on those severely imjured plaintiffs who are in greatest need of the full painand-suffering award for just compensation. This unjust burden appears to be a rather steep price to pay for any benefits that caps create by reducing legal uncertainty, which explains why this reform has been disfavored by courts and commentators. ${ }^{72}$

malpractice cases to $\$ 1,000,000$ from all providers for each occurrence). A numher of similar statutes were held unconstitutional by state courts. See infra note 72 .

68. See generally S.M. Waddams, Compensation for Non-Pecuniary Loss: Is There a Case for Legislative Intervention?, 63 CANADIAN B. REv. 734 (1985) (describing development of judicially imposed ceiling for pain-and-suffering damages in Canada).

69. According to one attomey who specializes in the defense of medical malpractice cases, "[t]here's no limit on what jurors can award for pain and suffering, so too oftcn they act like Santa Claus, handing out millions of dollars in cases involving comparatively minor injuries." James Griffith, What It Will Take to Solve the Malpractice Crisis, MED. Econ., Sept. 27, 1982, at 193, 195; see also Bovbjerg et al., supra note 3, at 917 ("There is virtually no upper bound to defendants' potential liability ....").

70. See Viscusi, supra note 38, at 216-17.

71. See infra note 111 and aceompanying text.

72. A number of state courts have struck down legislative caps on pain-and-suffering damages on the grounds that such limits violate state constitutional guarantees. See, e.g., ALA. CoDz § 6-5-544 (1993) (limiting noneconomic damages in personal injury actions to $\$ 400,000$ ). The Alabama Supreme Court held this section unconstitutional in Moore v. Mobile Infirmary Ass'n, 592 So. 2d 156, 171 (Ala. 1991). See also Or. Rev. STAT. $\$ 18.560$ (1993) (limiting noneconomic compensatory damages in all civil claims arising out of bodily injury to $\$ 500,000$ ). The Oregon Court of Appeals held this section unconstitutional in Tenold v. Weyerhauser Co., 873 P.2d 413 (Or. Ct. App. 1994) (en banc). 


\section{B. Schedules and Other Methods of Increasing Horizontal Equity}

Because the current system of awarding pain-and-suffering damages often fails to treat similarly situated plaintiffs alike, a number of different reform proposals seek to enhance the degree of horizontal equity in the system. The most direct method of achieving this equity is to provide jurors or reviewing courts with evidence of prior pain-and-suffering awards for similar cases. ${ }^{73}$ Schedules with categories based on mjury severity typically provide the method of classification, and prior awards for injuries within each category provide a range of damages amounts. The jury or reviewing court determines where the plaintiff's injury falls on the schedule, and the schedule provides a range or specified amount that can be binding or nonbimding on juries or courts. Although reforms of this type differ in their details, each proceeds from the premise that prior pain-and-suffering awards for similar cases provide the appropriate basis for computing the present award. ${ }^{74}$ These reforms therefore ensure that like plaintiffs are treated alike, assuming, perhaps heroically, that the schedule categories succeed in defining what constitutes a "similar mjury."

For examples of influential studies of tort reform that have rejected legislative ceilings on pain-andsuffering awards, see American Bar Association, Report of the Action Commission to Improve THE TORT Liabirty System i (I987); 2 ALI Study, supra note I0, at 2I8-2I.

73. For reform proposals that focus on giving this evidence to the jury, see James F. Blumstein et al., Beyond Tort Reform: Developing Better Tools for Assessing Damages for Personal Injury, 8 Y ALE J. ON REG. 17I, 178-79 (1990) (proposing that prior damage awards should be given precedential value for future damage awards; awards that are within the middle range of prior awards are given presumptive validity; and awards that differ significantly from prior cases are subject to a "burden of explanation by the jury and heightened review by the court"); Bovbjerg et aI., supra note 3, at 938-65 (proposing three different scheduling models to help jurors calculate pain-and-suffering awards: a binding schedule of awards based on severity of injury and age of injured party; "a small set of paradigmatic injury 'scenarios'" with suggested, nonbinding dollar values based on past experience; and "a system of flexible floors and ceilings" for noneconomic awards that vary with injury severity and victim age); Chase, supra note 43 (proposing that jurors in all personal injury actions be given a nonbinding chart summarizing the range of awards-low, median, and high-made by other juries in the same state during a contemporaneous time period for different categories of injury severity); Levin, supra note 44, at 310 (proposing binding "guidelines [that] would inform juries of the value for pain and suffering assigned by a large number of juries to injuries similar to those before the factinder"). A schedule was also discussed in 2 ALI STUDY, supra note 10, at 223-27, although there was no indication regarding the source of the scheduled awards. However, those who participated in the study subsequently indicated that the scheduled awards could be derived from prior jury awards. See Abraham et aI., supra note 62, at 343 (in implementing the schedule proposed in the ALI study, "[d]ecision-makers can be greatly assisted by knowledge of the actual awards that juries within the jurisdiction have made for different classes of injury.").

For reform proposals that focus on allowing reviewing courts to use prior awards for the basis of evaluating whether the current award is appropriate, see David C. Baldus et al., An Empirically Based Methodology for Additur/Remittitur Review and Alternate Strategies for Rationalizing Jury Verdicts, in CIVIL JUSTICE REFORM IN THE 1990s, supra note 43 (proposing a method for additur/remittitur review involving comparison of awards in similar cases); Leebron, supra note 18, at 323 ("[S]tates should require reviewing judges to formulate aeceptable ranges for awards, taking into account possible factual variations.").

74. The desirability of basing scheduled damages awards on nonjury determinations of the cost of injury is discussed infra Part VII.B. 
This reliance upon past awards also represents the most problematic aspect of these reform proposals. If the system has been providing overly arbitrary pain-and-suffering awards, and if we have no method for determining the appropriate award in the first instance, why should we make prior awards the cornerstone of future awards? By doing so, we may ensure that like cases are treated alike in that all involve inappropriate damages awards. ${ }^{75}$

Moreover, although the current system provides a degree of vertical equity in that more severe injuries tend to receive inore coinpensation, ${ }^{76}$ more severe ijjuries may not be accorded the appropriate anount of additional compensation. To the extent that certain types of injury currently receive more or less compensation than they should relative to other injury types, there is a degree of vertical inequity in the present system that would be sustained by reforms that rely on prior awards to determine the appropriateness of future awards.

The need to determine injury categories poses another problem with schedules. In effect, injury categories provide an objective ineasureinent of the severity of the plamtiff's pain-and-suffering injury. However, there is no test for objectively measuring an individual's pain and suffering, ${ }^{77}$ so mjury categories will often improperly measure the severity of the plaintiff's mjury. Allowing for a wider range of available damages within each mjury category would ameliorate this problem, but it would also undermine one of the benefits of scheduling: the ease of determining the plaintiff's award. Furthermore, studies have shown that individuals' monetary assessments of imjuries depend not only on the severity of injury, but also on the nature of the risk that caused the injury. ${ }^{78}$ The appropriate pain-andsuffering award im an mdividual case consequently will often depend upon a variety of factors that may be difficult to standardize.

The difficulty of achieving justice im the individual case while introducing uniformity via the use of schedules is illustrated by the federal courts' implementation of the Umited States Sentencing Guidelines. ${ }^{79}$ That

75. See Peter Schuck, Scheduled Damages and Insurance Contracts for Future Services: $A$ Comment on Blumstein, Bovbjerg and Sloan, 8 YALE. J. ON REg. 213, 218 (1990); cf. P.S. ATrYAH, ACCDENTS, COMPENSATION AND THE LAW 213 (3d ed. 1980) ("[T]he calculation of [pain-and-suffering] damages is to a very large extent arbitrary. ... All such damage awards could be multiplicd or divided by two overnight and they would be just as defensible or indefensible as thcy are today.").

76. See supra notes $40-42$ and accompanying text.

77. See supra note 21 and accompanying text.

78. See, e.g., Ian Savage, An Empirical Investigation into the Effect of Psychological Perceptions on the Willingness-to-Pay to Reduce Risk, $6 \mathrm{~J}$. RISK \& UNCERTAINTY 75 (1993) (describing study showing that different hazards will produce different estimates for the price of injury-in this casc, death-because willingness-to-pay increases with the dread of the hazard but declines with the degree of knowledge that people have about the risk in question).

79. See, e.g., Daniel J. Freed, Federal Sentencing in the Wake of Guidelines: Unacceptable Limits on the Discretion of Sentencers, 101 YALE L.J. 1681, 1683-84 (1992) ("History teaches that statutorily imposed mandatory scritences are unjust and often nullificd by juries, judges, and prosecutors. The 
experience indicates that scheduling pain-and-suffering damages inay not be an improveinent over the current systein. ${ }^{80}$

\section{Abolishing Awards for Pain and Suffering in Contractual Settings}

Tort rules in contractual settings, most notably products liability, are widely recognized to be designed to achieve efficient outcomes. ${ }^{81}$ Consequently, due to their view that pain-and-suffering damages are inefficient in these cases, a number of scholars have concluded that these damages should be eliminated. ${ }^{82}$ The conclusion stems from the economic analysis of insurance, which shows that consumers often would prefer for efficiency reasons that there be no tort dainages for pain and suffering. ${ }^{83}$

An insurance analysis is appropriate because tort damages represent a form of insurance against the injury in question. ${ }^{84}$ As such, if prior to injury an individual would prefer to have no insurance against the loss in question, then the individual's pre-injury preference is that the tort system should provide no compensation for such losses. Of course, individuals would prefer to have insurance when it is provided at no cost to them. But in contractual settings, individuals pay for the insurance provided by tort dainages because such damages increase the purchase price of the good or service that exposes these individuals to the risk of injury. ${ }^{85}$

In determining how much insurance coverage is optinal, the purchaser of insurance recognizes that she must pay money now in exchange for the receipt of money later should the insured event occur. Increased insurance expenditures thus reduce the policyholder's well-being in the noninjured

imposition of 'mandatory guidelines' by the [United States Sentencing Commission] is now spawning similar lessons.") (footnote omitted).

80. To be sure, there are other areas where schedules appear to be working more successfully. For example, British trial and reviewing courts look to a tariff-like schedule for determining presumptive general damages awards for " "various types of commonly occurring injuries." " Housecroft v. Bumett, [1986] 1 All E.R. 332, 336-38 (1985). Moreover, many of the problems can be overcome if the source of past awards is more appropriate and uniform than the present sources. See infra Part VII.B.2.

81. See, e.g., George L. Priest, Products Liability Law and the Accident Rate, in LiaBIIIT: Perspectives AND Policy 184, 185 (Robert E. Litan \& Clifford Winston eds., 1988) ("Virtually all courts and commentators have embraced the goals of accident reduction and insurance that eorrespond to the principal economic effects of the law."); see also 1 ALI STUDY, supra note 10, at 30-32 (asserting that "the generally prevailing scholarly theory" of tort law is based on the efficient control of accident costs); Coleman, supra note 13, at 407-29 (accepting the efficiency criterion for products liability while rejecting it as the best explanation of tort law).

82. See supra note 13 .

83. This argument is based on Cook \& Graham, supra note 12. Good expositions of it are provided in Shavel, supra note 48, at 228-35; Schwartz, supra note 13, at 362-67, 408-11.

84. See 2 ALI STUDY, supra note 10, at 206 (describing tort law as "a port of entry into an insurance program paid for and provided by members of the community").

85. For example, a manufacturer subject to tort liability for pain and suffering includes its potential liability cost for such injuries in the price of the product. The eonsumer therefore in effect pays a premium for the pain-and-suffering insurance provided by the tort system, and so whether the consumer prefers the insurance provided by the tort award depends upon whether the consumer prefers to receive such insurance in exchange for the implicit premium paid in the form of higher product prices. 
state of the world while enhancing her well-being in the injured state. To maximize utility, the individual needs to purchase the amount of insurance that maximizes expected utility over these two states. If $\$ 1$ provides less utility to the consumer $m$ the noninjured state than it does following the injury, the consumer can increase utility by transferring this dollar into the mjured state via the purchase of insurance. Expected utility is maximized if the individual continues to spend inoney on insurance until the marginal utility of money is equal in the injured and noninjured states, because at this point it is not possible to increase utility further by using insurance to transfer inoney between the two possible states of the world.

Injuries of a purely monetary nature do not change the individual in the sense that her ability to derive utility or satisfaction from any given level of wealth is altered. Rather, a monetary injury lowers an individual's utility by reducing lier wealth. With fewer total dollars available, individuals are likely to value eacli dollar more. Injuries that reduce wealth, therefore, increase the marginal utility of wealth for inost individuals. Thus, for purely monetary injuries, an individual can increase expected utility by transferring inoney into the mjured state of the world through the purchase of insurance. When insurance is actuarially fair, expected utility is inaximized at the level of full insurance. ${ }^{86}$ Economic theory therefore predicts that individuals would seek full insurance for pure inonetary losses (lost wages, inedical bills, and so on) if msurance were actuarially fair.

The analysis is inore coinplicated for nonmonetary losses. Pain and suffering is not analytically equivalent to a reduction in wealth, because the mjury does not affect the imdividual's wealth but instead reduces her wellbeing at that level of wealth relative to the pre-injury state. Pain and suffering consequently alters the individual's utility function because the individual receives less utility for any given level of wealth following the accident. Such an alteration in the utility function, however, affects the marginal utility of wealth in an indeterminate way: the pain-and-suffering injury may either increase, decrease, or not affect the individual's ability to derive satisfaction from money.

Only when the accident increases the individual's marginal utility of wealth will the individual find it efficient to purchase insurance to cover the loss. For example, an imjury increases an individual's marginal utility of wealth if it renders the victim unable to engage in activities that fornerly gave her great pleasure (for example, hiking) and the substitute activities that can give her similar pleasure are more costly (for example, going to theatrical events). It would be rational for individuals to purchase insurance coverage for sucli an injury, though this amount may be less than full compensation. ${ }^{87}$ Alternatively, the injury may be such that the victim suffered significant pain for a sliort period but can still enjoy life just as she did

86. See e.g., Hal R. VARIAN, Microeconomic ANalysis 180-81 (3d ed. 1992).

87. See Shavell, supra note 48 , at 246. 
before the injury. Because injuries of this type do not affect the victim's ability to derive pleasure from the use of money, the individual's marginal utility of wealth is already equalized in the injured and noninjured states of the world. Purchasing insurance for the injury would not increase her expected utility, In a third scenario, if the pain-and-suffering imjury lowers the inarginal utility of wealth (for example, if the victim becomes comatose), then optimal insurance is negative. The individual would prefer to transfer wealth from the injured state (unconsciousness) to the noninjured state (healthy and conscious), where more utility can be derived froin each dollar.

In theory, a nonmonetary injury may affect the marginal utility of wealth in any one of these three ways. ${ }^{88}$ The argument that tort damages for pain and suffering are an inefficient form of insurance thus assumes that such injuries either lower or do not affect the marginal utility of wealth, an assumption that does have empirical support. ${ }^{89}$ A strong case can be made, then, for eliminating pain-and-suffering damages for situations in which potential victims pay for the prospect of tort damages (imsurance) in the form of higher prices (premiums).

Unlike other reform proposals, this proposal directly addresses the issue of how much tort compensation is appropriate to compensate a particular mdividual for the pain-and-suffering injury she has incurred. However, it is subject to the criticism that pain-and-suffering imjuries do not necessarily reduce or leave unaffected the victim's marginal utility of wealth, so that consumers would prefer at least some insurance against such injuries. ${ }^{90}$ Studies have shown that consumers prefer some insurance for certain kinds of pain-and-suffering injuries. ${ }^{91}$ Indeed, individuals do purchase some

88. See David Friedman, What Is 'Fair Compensation' for Death or Injury?, 2 INr'L Rev. L. \& ECON. 81 (1982).

89. W. Kip Viscusi \& William N. Evans, Utility Functions That Depend on Health Status: Estimates and Economic Implications, 80 AM. Econ. Rev. 353, 371 (1990) (describing empirical study showing that 'the marginal utility of a given Ievel of income [is] greater when [the individual is] healthy than when injured.").

90. See Steven P. Croley \& Jon D. Hanson, The Nonpecuniary Costs of Accidents: Pain and Suffering Damages in Tort Law, HARv. L. REv. (forthcomiug 1995) Thereinafter Croley \& Hanson, Nonpecuniary Costs]; Steven P. Croley \& Jon D. Hanson, What Liability Crisis? An Alternative Explanation for Recent Events in Products Liability, 8 Y ALE J. oN REG. 1, 60 (1991); Jon D. Hanson \& Kyle D. Logue, The First-Party Insurance Externality: An Economic Justification for Enterprise Liability, 76 CorNell L. Rev. 129, 183-84 \& n.205 (1990).

The empirical study by W. Kip Viscusi and William Evans finding that pain-and-suffering injuries lower the marginal utility of money, see Viscusi \& Evans, supra note 89 , at 371 , can be criticized because it relies upon the perspective of nondisabled individuals who are unlikely to have enough information to determine their compensation needs following a disabling injury. See infra note 225 and accompanying text.

91. See John E. Calfee \& Clifford Winston, The Consumer Welfare Effects of Liability for Pain and Suffering: An Exploratory Analysis, 1 BrookIngs Papers on ECONOMIC ACtivity: MICROECONOMICS 133, I51 (1993) (summarizing survey results finding that consumers prefer some insurance for a variety of pain-and-suffering injuries); Jeffrey O'Connell, A Proposal to Abolish Defendants' Payment for Pain and Suffering in Return for Payment of Claimants' Attorneys' Fees, $2 \mathrm{U}$. 
forms of insurance, such as uninsured notorist coverage, that provide coinpensation for pain-and-suffering injuries. ${ }^{92}$

These points, though valid, do not justify full compensation. Some pain-and-suffering injuries undoubtedly increase the individual's marginal utility of money (so that the individual would want to purchase soine insurance agamst those imjuries), but other injuries undoubtedly decrease the inarginal utility of money. ${ }^{93}$ Consequently, full compensation would provide too inucli insurance for the range of pain-and-suffering injuries compensable in tort.

Thus, although insurance considerations do not necessarily demand the elimination of pain-and-suffering damages, the insurance theory does provide a good argument for reducing pain-and-suffering damages below the level of full compensation. Indeed, coupling this conclusion with the concerns about the difficulty of measuring these damages could lead one to conclude that paim-and-suffering damages should be eliminated because the costs created by measurement error and the inefficiency of full compensation outweigh the benefits of a fully-compensatory pain-and-suffering award.

The persuasiveness of this position requires that it be fully addressed. Consequently, in the analysis that follows I will show why the insurance theory provides weak support for the conclusion that efficiency requires that pain-and-suffering dainages be reduced below the level of full compensation.

\section{IV}

\section{A Justification For Full COMPENSATION UNDER the CURRENT SYSTEM}

The insurance theory provides the strongest justification for reducing or eliminating pain-and-suffering damages when the injury reduces the marginal utility of inoney of a plaintiff who is in a contractual relationship with the defendant. However, even if we assume (unrealistically) that all painand-suffering injuries are of this type, it is difficult to sustam the argument that tort compensation for these injuries is an inefficient form of insurance because the argument proceeds froin assumptions that are unrealistic. Once

ILL. L. Rev. 333, 363-65 (1981) (summarizing results of two public surveys that found that of the various reasons for carrying automobile insurance, $80 \%$ to $90 \%$ of the respondents felt that compensation for pain and suffering was very important or fairly important); see also W. KIP VIScusI, Fatai Tradeoffs: PUblic and Private ResponsibLmites for RisK 89 (1992) (survey results indicating that "consumer utility functions for minor injuries do indicate a demand for pain and suffering insurance.").

92. For an extensive analysis of the various ways in which individuals purchase some form of insurance against pain-and-suffering injuries, see Croley \& Hanson, Nonpecuniary Costs, supra note 90.

93. The tort system currently provides full compensation for injuries that undoubtedly decrease the victim's marginal utility of wealth. See Adcox v. Children's Orthopedic Hosp. \& Medical Ctr., 864 P.2d 921, 927, 932 (Wash. 1993) (upholding award of noneconomic damages of $\$ 4,628,750$ for infant who suffered brain damage so severe that he would never reach a mental age of more than one year). 
more realistic assumptions are adopted, it becomes possible to square full compensation under the current system with efficiency considerations. This conclusion applies with even greater force to the types of pain-and-suffering injuries that do not reduce the marginal utility of money, as the insurance theory provides an even weaker argument for reducing or eliminating painand-suffering damages for such injuries. ${ }^{94}$

\section{A. Revising the Unrealistic Assumption of Perfect Information}

Recall that the imsurance analysis which shows that pain-and-suffering damages are inefficient assumes that tort damages (as insurance) perform the single function of transferring money from the pre-accident to postaccident state of the world. The insurance analysis thus assumes that there is no deterrence value to tort awards. ${ }^{95}$ This assumption would be true if everyone had perfect information about product risks, since tort liability is not needed in that situation to promote product safety. ${ }^{96}$ Tort rules may lead to more efficient outcomes than contracting, however, if informational problems cause consumers to undervalue the full cost of product-caused injuries. In that case, consumers would purchase products that are insuffciently safe, so tort liability is needed to induce manufacturers to increase their investments in product safety. The tort system is therefore based on the premise, which has empirical support, that tort liability is needed for deterrence purposes because informational problems prevent consumers in contracting situations from purchasing products that are sufficiently safe. ${ }^{97}$

94. It should also be recognized that the insurance critique of pain-and-suffering damages is less persuasive for injuries that occur in noncontractual settings. As described infra Part VI, there is a large degree of similarity between the contractual and noncontractual settings in that individuals in noncontractual settings may still pay for the pain-and-suffering insurance provided by the tort system due to the possibility that each individual is both a potential injurer and a potential victim for many types of injuries. But there are cases in which the potential beneficiaries of tort awards do not pay for all, or even some, of the insurance provided by the tort system, and so these individuals would probably not prefer that such damages be reduced or eliminated. Thus, the insurance analysis of pain-and-suffering damages developed in the context of contractual relationships is applicable to some, but not all, torts involving noncontractual relationships.

95. Analytically, the result that the optimal amount of insurance equates the marginal utility of wealth in the two states assumes that the other conditions for optimahty, including optimal precautions, are met. See infra app. $\S 1$. Others have also recognized that the insurance analysis of pain-andsuffering damages omits consideration of the deterrence value of the tort award. See, e.g., Shavelt, supra note 48, at 233-34 \& n.5; Daniel L. Rubinfeld, On Determining the Optimal Magnitude and Length of Liability in Torts, $13 \mathrm{~J}$. LEGAL STUD. 551, 553-54 (1984).

96. This assumes that no externahities are involved. For a more thorough discussion of when tort rules may lead to more efficient outcomes than contracting, see Mark Geistfeld, The Political Economy of Neocontractual Proposals for Products Liability Reform, 72 TEx. L. REv. 803, 809-14 (1994).

97. See, e.g., Barker v. Lull Eng'g Co., Inc., 573 P.2d 443, 454 (Cal. 1978) (holding that consumer expectations regarding product safety supply only a minimum standard of product safety to which manufacturers must couform in order to avoid tort liability, because imperfectly informed consumers may not demand as much safety as would be desirable). Consumers will not demand an efficient amount of safety if they underestimate the risk of injury. A variety of well-established social science research findings support the conclusion that consumers tend to underestimate product risks most of the time. See Howard Latin, "Good" Warnings, Bad Products, and Cognitive Limitations, 41 
Accordimgly, a more realistic efficiency analysis of pain-and-suffering damages, and one that is consistent with the underlying premises of the tort system, should account for the deterrence value created by these tort awards.

Incorporating deterrence considerations alters the analysis and leads to a very different characterization of the efficient tort award for pain-andsuffering damages. Each dollar of cost created by tort compensation that is "excessive" from a pure insurance perspective (one that does not account for the deterrence value of the award) is nevertheless cost-effective if by mcreasing safety it reduces expected accident costs by more than one dollar. ${ }^{98}$ Whereas the efficient amount of compensation in a situation of perfect information equates the marginal utility of wealth in the pre- and postaccident states, the efficient amount of compensation under conditions of imperfect information equahizes the marginal cost of excessive imsurance with the marginal benefit of increased product safety. In view of this difference, even if perfectly informed consumers would prefer zero or negative compensation for certain types of nonmonetary injuries, it may be efficient under conditions of imperfect information to provide consumers with positive pam-and-suffering tort awards for the same imjuries. ${ }^{99}$

UCLA L. REv. 1193, 1241 (1994). For an empirical study finding that tort law provides a significant amount of deterrence, though less than that predicted by some economic models, see Gary T. Schwartz, Reality in the Economic Analysis of Tort Law: Does Tort Law Really Deter?, 42 UCLA L. REv. 377 (1994).

98. The analytical results in this Part are derived in the Appendix, $\$ 2$.

99. The formal analysis in the Appendix that establishes this result is a direct extension into tort settings of the model developed in Samuel A. Rea, Jr., Nonpecuniary Loss and Breach of Contract, $11 \mathrm{~J}$. LEGAI STUD. 35 (1982). Kip Viscusi has also analyzed pain-and-suffering damages in this manner, albeit without a formal model. See Viscusi, supra note 8, at 92-94; see also Michael Spence, Consumer Misperceptions, Product Failure and Producer Liability, 44 REv. EcoN. Stud. 561, 565 (1977) (explaining that to determine the efficient level of manufacturer liability when such liability is the only available policy instrument, "one would have to trade off (i) providing surrogate incentives for producers to supply safety and (ii) providing consumers with insurance or protection against the residual risks").

By contrast, in a formal analytical treatment of the problem, John Calfee and Paul Rubin lave shown that a pain-and-suffering award that sceks to promote the deterrence objective will be incfficient for a number of reasons:

These include the requirement (in most situations) for consumers to purchase more than the desired level of insurance, the likelihood of supraoptimal precautionary incentives for sellers, the strong possibility that juries will overestimate the pain and suffering component .... and, finally, the fact that product price under strict liability will fail to signal risk to uninformed consumers and will distort the choices of informed consumers.

Calfee \& Rubin, supra note 13, at 382-83. The problem with this conclusion is that Calfee and Rubin avoid consideration of deterrence issues by assuming that courts ignore the interaction between damages payments and the injurer's incentive to take prccautions. Id. at 385 . Even if this assumption accurately characterizes current judicial practice, it does not follow that manufacturers or other sellers subject to tort liability ignore this liability when they determine how much precaution they should take. See 1 ALI STUDY, supra note 10 , at 32 (observing that tort liability is likely to influence manufacturer safety investments). By contrast, the analysis here assumes that manufacturers accoant for tort liability costs when they make safety investments, which is why such awards are valuable to consumers as a form of deterrence. 
The foregoing analysis creates a practical difficulty in that the efficient tort award, while positive, will not ordinarily be equal to full compensation. It is not feasible to reduce the damages award from full compensation to the efficient amount in each case, because the calculation is complicated and relies upon data that are not generally available. ${ }^{100}$

To avoid this problem, in theory, the court could award zero damages for pain and suffering if doing so would be efficient from a pure imsurance perspective, and instead impose a fine on the manufacturer. This fine would give the manufacturer an incentive to consider the full cost of painand-suffering injuries when it determines how much to imvest in product safety (thereby satisfying the deterrence objective). ${ }^{101}$ In practice, however, this method may not be feasible since the majority of cases are currently settled out of court. ${ }^{102}$ For these cases, the approach would cause a substantial increase in administrative costs if an additional judicial proceeding were required to calculate (and collect) the fine. ${ }^{103}$ Moreover, the scheine

100. The required data are the differences in the pre- and post-accident utility functions; differences in the pre- and post-accident marginal utility functions; the probability of accident and its first and second derivatives with respect to the manufacturer's safety investments; and the second derivative of the manufacturer's cost function with respect to safety investments. See infra app. equation (9). For a discussion of the difficulties that courts would face in evaluating evidence pertaining to the victim's preand post-accident marginal utility functions, see Ellen Smith Pryor, The Tort Law Debate, Efficiency, and the Kingdom of the Ill: A Critique of the Insurance Theory of Compensation, $79 \mathrm{VA}$. L. REv. 91, 107-25 (1993).

101. Proposals of this type are analyzed in Shavers, supra note 48, at 233-34; Patricia M. Danzon, Tort Reform and the Role of Government in Private Insurance Markets, $13 \mathrm{~J}$. LEGAL Stud. 517, 520-22 (1984); A. Mitchell Polinsky \& Ycon-Koo Che, Decoupling Liability: Optimal Incentives for Care and Litigation, 22 RAND J. ECON. 562 (1991); Spence, supra note 99. In addition to the practical problems created by this proposal, there is a theoretical difficulty that las not been fully appreciated. The fine will increase the price of the product, thereby reducing consumer demand below optimal levels. Shavell and Spence each show that the adverse price effects can be eliminated if all of the fines collected from a manufacturer are rebated to all consumers of the product, as each rebate should equal the expected value of the fine. Neither Shavell nor Spence explicitly recognize, however, that under this approach, the manufacturer might not lave to include the fine in its cost-minimization problem. All else being eqnal, if the consumer were to get a full rebate for whatever implicit price she pays for the fine, the total price perceived by the consumer may be independent of the size of the fine. If so, then manufacturers would not have an incentive to minimize the size of the fine; that is, manufacturers would need not concern themselves about the pain-and-suffering damages caused by their products. Thus, if rebates were to be included as part of the system of fines, efficient deterrence would be achieved only if consumers were to treat the amount of fine as a signal of product safety; that is, if consumers perceived all else to be equal, they would choose products with lower fines (and lower rebates) over other products with higher fines (and higher rebates).

102. See 2 ALI Study, supra note 10, at 213-16.

103. See id.; Rubinfeld, supra note 95, at 553-57. But see Polinsky \& Clie, supra note 101, at 566 67 (analysis showing that settlements which result in the defendant paying money only to the plaintiff may be as efficient as trials in which the plaintiff receives reduced damages and the defendant pays fines to the state for plaintiff's injuries). But even if a system of fines is not undermined by settlements, the approach may not be feasible since the optimal amount of damages for the plaintiff and the optimal fine for the defendant depends upon a number of case-specific factors for which courts may not have good information. Compare id. at 566. Moreover, agency problems in the plaintiff-lawyer relationship render the theoretical attributes of decoupling schemes indeterminate, making "it more difficult to use them as a policy tool." Marcel Kahan \& Bruce Tuckman, Special Levies on Punitive Damages: Decoupling, Agency Problems, and Litigation Expenditures, 15 INT'L REV. LAW \& EcoN. 175, 176 (1995). 
invites side-payments which allow manufacturers to avoid the fine and consumers to receive some coinpensation. A inore feasible approach is for the inanufacturer to pay the "fine" to the injured consuiner in the form of damages.

It would appear, then, that tort damages for pain and suffering inust serve both the insurance and deterrence functions of tort law, suggesting that pain-and-suffering damages should be positive but less than full compensation. This returns us to the problein of how to determine the appropriate reduction below full compensation given the lack of evidence on how to derive the efficient, partially coinpensatory award. We need not resolve this problein, however, because victiins do not currently receive the efficient ainount of compensation for all of their tortiously caused injuries. ${ }^{104}$

\section{B. Revising the Unrealistic Assumption of Optimal Compensation}

The argument that pain-and-suffering damages are inefficient assuines that victims are optimally coinpensated for all their tort injuries. For exainple, the imsurance analysis ignores other types of injuries. This omission is potentially significant, because if consumers are not compensated for all of their tortiously caused injuries, then on balance they may be underinsured. Consequently, any overinsurance provided by the pain-and-suffering award inay be offset, perhaps completely, by the underimsurance for other injuries. Thus, the claim that pain-and-suffering damages are an inefficient form of insurance relies on the assumption that the tort system otherwise provides damages that do not leave consumers inefficiently underinsured.

In any event, if we were to adopt a system of fines to replace jury awards for pain-and-suffering damages, we would still require a monetary measure of the plaintiff's injury. See Polinsky \& Che, supra note 101, at 566. The damages measure proposed here would therefore still be useful in such a system.

104. In the event that this problem needs to be addressed, a promising (though imperfect) solution is suggested in 2 ALI STUDY, supra note 10. This study proposes that pain-and-suffering damages be scaled downwards from the level of full compensation as the severity of injury decreascs. Compensation for the most serious injuries would be set equal to the statutory ceiling on pain-andsuffering damages. As the severity of injury diminishes, there would be larger reduetions in the award from the level of full compensation so that the amount of the award ultimately tapers off to a statutorily set floor for minor nonmonetary injuries. Id. at 217-27. Plans that have these same basic features have also been proposed by Paul C. Weiler, Medical Malpractice on Trial 58-61 (1991); Stcphen D. Sugarman, Doctor No, 58 U. ChI. L. REv. 1499, 1507-10 (1991) (reviewing PaUl C. WeIler, MedicaI Malpractice on Trias (1991)).

In many respects, this reform appears to provide a good method for incorporating deterrence considerations into the compensation analysis. There is a greater deterrence value for more severe injuries, and thus it would seem that the pain-and-suffering award should increase with injury severity. This outcome is not necessary, however, which is why this proposal does not fully solve the problem of how to determine efficient but partial compensation levels for pain and suffering.

Recall that the optimal tort award for pain and suffering equates the marginal benefit of aecident reduction with the marginal cost of excessive insurance. Although the marginal benefit of the tort award increases with the severity of injury, the marginal cost of the award may also increase with injury severity. Consequently, increasingly severe injuries do not necessarily eall for increasingly large painand-suffering awards. See infra app. $\S 3$. The proposal put forth by the ALI Study therefore is unlikely to result in efficient compensation levels for pain-and-suffering injuries. 
This assumption of optimal compensation is unrealistic because there are a number of losses that consumers incur as a result of tortious conduct for which the tort system currently provides no compensation. Indeed, the tort system does not even "purport to redress all material losses, physical or mental." 105

Most obviously, the tort system provides no compensation for the plaintiff's legal expenses. Studies indicate that about one-third of the total compensation paid to plaintiffs is consumed by legal fees. ${ }^{106}$ As a result, pain-and-suffering dainages have often been justified on the ground that these awards in effect compensate the plaintiff for lier legal expenses. ${ }^{107}$ Compensating plaintiffs for their legal fees through higher dainages awards may be more efficient than compensating plaintiffs directly for these costs. ${ }^{108}$ In any event, a reform that reduces paim-and-suffering damages on the ground that such awards provide more insurance than consumers prefer should account for the fact that plaintiffs would then be unable to recover their attorneys' fees. ${ }^{109}$

It is difficult to determine whether consumers are generally undercompensated for tortiously caused financial losses other than legal fees, particularly smce they may be insured for some portion of the loss not covered by the award. Moreover, if the insurance covers a loss for which the plaintiff receives tort coinpensation, the plaimtiff may receive double compensation for the loss. ${ }^{110}$ The difficulty of determining whether consumers as a group are undercompensated for tortiously caused financial losses other than attor-

105. Ingber, supra note 16 , at 775 . For an analysis of the ways in which tort law fails to recognize various types of injuries, such as the value of nonmarket time for a market-employed victim, see Neil $\mathrm{K}$. Komesar, Toward a General Theory of Personal Injury Loss, 3 J. LEGAL STUD. 457 (1974).

106. See James S. Kakalik \& Nicholas M. Pace, Costs and Compensation Paid in Tort LITIGATION 68-69 \& tbl. 7.2 (1986) (describing study showing that for average tort lawsuit in 1985, approximately $30 \%$ to $31 \%$ of total compensation paid to plaintiffs was used to pay plaintiffs' legal fees and expenses).

107. See Greene, supra note 37 , at 24 I-42 (summarizing studies that indicate that jurors at times add an amount to the compensatory award to cover plaintiff's attorneys' fees); see also Seffert v. Los Angeles Transit Lines, 364 P.2d 337, 345 (Cal. 1961) (Traynor, J., dissenting) (recognizing damages for pain and suffering is a proper means of enabling prevailing plaintiff to pay attomeys' fees not otherwise compensated by the litigation, but arguing majority erred in affirming excessive award).

108. See Louis Kaplow, Shifting Plaintiffs' Fees Versus Increasing Damage Awards, 24 Rand J. ECON. 625 (1993) (showing that use of higher damage awards is more efficient than shifting plaintiffs' fees, since substituting higher damage awards for fee shifting would not affect deterrence but would eliminate the suits of plaintiffs with the highest litigation costs).

109. A number of reform proposals have proceeded on this basis. E.g., 2 ALI STUDY, supra note 10, at 215-16; see also Abraham et al., supra note 62, at 344 ("A crucial corollary to this new approaeh to damage awards [advocated in the ALI Reporters' Study] is its treatment of plaintiff's attorney fees.") (footnote omitted); see also O'Connell, supra note 91, at 351; Ingber, supra note 16, at 812 ("[T] proposed abolition of general damages for pain and suffering and emotional distress in all but willful torts is desirable only if courts will grant attorney fees to successful litigants.").

110. This would occur if the plaintiff were not subject to subrogation from the insurer and the tort award were not subject to reduction due to the collateral-source rule. For a good discussion of these rules and explanations for why insurers are not always able to subrogate, see 2 ALI STUDY, supra note 10 , at $162-64$. 
neys' fees (for which consumers cannot obtain first-party insurance) is further coinpounded by studies showing that plaintiffs with high econoinic losses generally recover only a portion of those losses whereas plaintiffs with low economic losses tend to be overcompensated. ${ }^{111}$

With respect to nonmonetary injuries, undercoinpensation occurs because the tort system does not presently provide damages for the full range of nonmonetary injuries caused by tortfeasors. Many jurisdictions, for exainple, do not provide for hedonic dainages in wrongful death actions. $^{112}$ If injured consumers were to receive damages for their lost enjoyment of life in wrongful death actions, "these damages could easily increase awards by a factor of ten, to levels that would dwarf the 'jackpot' awards in the news today." "113 Since consumers may be inefficiently underinsured for the nonmonetary injuries not presently coinpensable in tort, the cost-effectiveness of coinpensable pain-and-suffering injuries is often enhanced. To return to the example above, although damage awards for pain and suffering prior to death inay seem excessive when viewed in isolation, but these awards become much more reasonable once it is recognized that in inany jurisdictions the victim receives no coinpensation for the loss of life's pleasures following death. ${ }^{114}$

\section{Revising the Unrealistic Assumption of Perfect Enforcement}

Even for injuries that are presently compensable in tort, the insurance analysis as conventionally stated is unrealistic because "[d]efendants are protected froin the inajority of those they injure by the sinple fact that victiuns tend not to complain."115 This underclaiming by victins significantly reduces the cost of the pain-and-suffering insurance provided by the tort systein. For exainple, if a manufacturer is sued by a randoin sample of $50 \%$ of the consumers who have a valid clami for pain-and-suffering damages, the manufacturer bears liability for only $50 \%$ of the pain-and-suffering

111. "This pattern of overcompensation at the lower end of the range and undercompensation at the higher end is so well replicated that it qualifies as one of the major empirical phenomena of tort litigation ...." Saks, supra note 3, at 1218; see JAMES S. KAKALIR ET AL., CosTS AND COMPENSATION Paid in Aviation Accident Lmitiation 58 tbl. 4.7 (1988); Elizabeth M. Kino \& James P. Smith, ECONOMIC LosS AND COMPENSATION IN Aviation ACCiDENTS vii, xii (1988) (noting that aviation accidents, which obviate many of the uncertainties associated with most tort cases, result in tort compensation that, "on average, falls far below economie loss" and that large awards "may represent a fair adjustment to undereompensation for high-loss victims"); Frank A. Sloan \& Stephen S. van Wert, Cost and Compensation of Injuries in Medical Malpractice, 54 LAW \& ConTEMP. Pross. 131, 133 (1991).

112. See Tabacchi, supra note 28 , at $342-46$.

113. VIScUSI, supra note 8 , at 88 .

114. Compare DeLong v. County of Erie, 89 A.D. $2 d$ 376, 385, 455 N.Y.S. $2 d 887,893$ (N.Y. App. Div. 1982), aff'd 60 N.Y. 2d 296, 457 N.E. 2d 717, 469 N.Y.S. $2 d 611$ (1983) (jury award of $\$ 200,000$ for suffering plaintiff endured in the last 13 minutes of her life).

115. Saks, supra note 3 , at 1185 . For a description of a number of these studies and a discussion of the possible reasons for underclaiming, see Richard L. Abel, The Crisis is Injuries, Not Liability, in New Directions in Liabitity Law 31, 32-33 (Walter Olson ed. 1988). 
injuries it causes. It incurs total liability costs that are roughly equivalent to what it would face if $100 \%$ of the injured consumers with valid claims were to file suit and receive compensation for only $50 \%$ of their pain-and-suffering injuries. A manufacturer's total liability for pain-and-suffering damages inay therefore already approximate the efficient (partially compensatory) amount, so that consumers on average are getting the efficient amount of pain-and-sufferring insurance. The argument that pain-and-suffering damages are imefficient does not account for the substantial reduction in insurance costs caused by underclaiming. ${ }^{16}$

For a variety of reasons, then, full compensation for the nonmonetary injuries currently compensable in tort imposes a much smaller cost on consumers than is indicated by a theoretical analysis that omits deterrence considerations and assumes there is no underclaiming in a system that provides efficient compensation for the range of other losses suffered by consumers. Hence, althougli there is merit to the argument that tort damages for noninonetary injuries may not be desirable in principle due to the insurance preferences of consumers, a more realistic assessment of those preferences shows that consumers as a class probably prefer full compensation for those pain-and-suffering injuries currently compensable in tort. Furtherinore, there is a different argument that undermines the conclusion that pain-andsuffering damages provide more insurance than consumers would prefer, nainely, that paim-and-suffering injuries may increase the victim's marginal utility of wealth (so that consumers would prefer a damages award for the injury). ${ }^{117}$ On balance, the arguments for full compensation for pain-andsuffering damages prevail over those for reducing awards.

$\mathrm{V}$

The Proper Measurement of Pain-And-Suffering Damages in Contractual Settings

Although an insurance argument does not presently justify the reduction of pain-and-suffering awards below the level of full compensation, the

116. More formally, the argument here is that consumers may be paying less than the actuarially fair insurance premium (probability of injury times loss) for fully compensatory pain-and-suffering damages due to significant underclaiming by victims. The insurance analysis of the tort award thus overstates its costs because the analysis assumes that consumers pay this premium for the tort award even though underclaiming reduces the premium (by the probability of recovery). See infra app. $\$ 1$. Of course, underelaiming creates new costs for the injured consumers who pay for the pain-andsuffering insurance but ncver collect on it. The critieal point, lowever, is that on average consumers may be paying the appropriate amount for pain-and-suffering damages. The primary benefit of this payment lies in its deterrence value, a benefit that accrues to all consumers. Moreover, some consumers do receive an insurance benefit and most consumers do not need it because they have not been injured. Thus, the costs incurred by the deserving but uncompensated victims are likely to be significantly less than the benefits that pain-and-suffering damages provide to the vast majority of other consumers. Underclaiming therefore significantly affects the efficiency analysis in a manner not captured by the insurance theory.

117. See supra notes $90-92$ and accompanying text. 
tort system currently functions in a manner that indicates the theoretical benefits of the damages award may be dwarfed by the practical problems of measuring full compensation. ${ }^{118}$ The current system can be substantially improved upon, however, as there is a defcnsible method that would enable jurors to determine pam-and-suffering damages in a inanner that is consistent with the case law.

\section{A. The Ex Ante Full-Compensation Award}

Courts have held inappropriate the deternmination of the pain-and-suffering award by asking how inuch compensation the victim would require to accept the certainty of the injury she suffered. ${ }^{119}$ This holding implies that compensation should involve consideration of the risk of injury.

There is a straightforward way to derive a ineasure of full compensation from the underlying risk of injury. Let $p$ represent the probability that a product will cause the consumer to suffer a particular paim-and-suffering mjury. Assune the consumer is aware of this risk and able to choose the ainount of monetary coinpensation $M_{f}$ that would fully compensate her for the pain-and-suffering mjury. The inanufacturer will charge the consumer $p M_{f}$ as the actuarially fair imsurance premium for this fully compensatory insurance policy. Assume the consumer is now given the choice to pay something in order to eliminate the risk of suffering this particular injury. By doing so, she would eliminate the need for insuring against the injury and no longer have to pay the premium $p M_{f}$. The consumer therefore would be willing to pay up to $p M_{f}$ to eliminate the risk $p$ of incurring this particular pain-and-suffering injury. (Paying more than $p M_{f}$ would not be costeffective, since it would be cheaper for the consumer to pay for the insurance and face the risk). Thus, if $E(p)$ denotes the inaximum amount the consumer is willing to pay to eliminate the risk of incurring the nonmonetary injury in question, then $E(p)=p M_{f}$, and so $M_{f}=E(p) / p$. A damages award equal to $E(p) / p$ accordingly reflects the consumcr's pre-injury assessment of the amount that would fully coinpensate her for the particular

118. See supra Part II.

119. See 4 HARPER ET AL., supra note $19, \S 25.10$, at 563-64 ("All agree that [full compensation for pain and suffering] does not mean the sum that the plaintiff-or anyone else-would be willing to suffer the injury for."); 8 American Jurisprudence Pleading and Practice Forms Annotated 278 (1982) (instrueting a jury not to fix the pain-and-suffering award by the amount sufficient to induce a person to suffer certain injury). Relatedly, courts have rejected the "Golden Rule" argument which asks jurors to determine the award by asking themselves how much money they vould want in exchange for experiencing the plaintiff's pain and suffering. See generally L.R. James, Annotation, Instructions in a Personal Injury Action Which, in Effect, Tell Jurors That in Assessing Damages They Should Put Themselves in Injured Person's Place, 96 A.L.R.2D 760 (1964). The courts have rejected this argument because it invites sympathy or bias by the jurors. Id. at 761. The unacceptable bias stems in part from the way in whieh the argument defines the appropriate damages award as the exchange of money for the certainty of injury. See infra note 159 (explaining why certainty of injury is likely to yield incorrect darnages measure). 
pain-and-suffering injury she has incurred, ${ }^{120}$ which is why it can appropriately be called "the ex ante full-compensation award."

The reason this calculation yields a measure of full compensation can also be explained in a different way. ${ }^{121}$ Increased product safety ordinarily imposes a cost (in the form of higher prices) on consumers, which forces them to decide whether it is desirable to spend more money in exchange for a reduced chance of imjury. In choosing between spending more inoney on safety or facing a risk of imjury, the imdividual balances the cost of reducing or eliminating the risk against the benefit of the risk reduction. Because the benefit is the avoidance of the injury in question, the cost that the consumer is willing to pay to achieve this safety benefit-which is captured by the measure $E(p)$-provides a measure that reflects the consumer's ex ante assessment of the cost of the pain-and-suffering injury.

To illustrate how the jury could derive the ex ante full-coinpensation award, consider a case in which the consumer was injured by a product defect. Assume the evidence shows that the plaintiff suffered severe lung damage, leaving her in a fair amount of pain and unable to engage in athletic activities that had previously given her great pleasure. Assume also that the odds are 1 in 10,000 that the product defect would result in the plaintiff's suffering an injury of this severity. ${ }^{122}$ In order to determine the ex ante full-compensation award, after receiving evidence on the severity of the plaintiff's injury, the jury could be told that it should determine the award by answermg the following question: "What is the maximum amount that a reasonable person would have been willing to pay to eliminate a 1-in-10,000 risk of ending up with an imjury as severe as the plaintiff's pain-and-suffering injury?"123 If, for example, the jury arrived at a

120. This formulation of the damages measure is subject to the criticism that insurance is not actuarially fair. The more direct way to make this objection is to recognize that individuals who are risk averse are wilhing to pay an amount to eliminate risk in excess of the expected value of the injury. The risk measure $E(p)$ consequently captures the expected value of injury, as argued above, plus the cost that risk-averse individuals bear when they are exposed to uncertain outcomes that affect their well-being. Thus, for example, risk-averse individuals might be willing to pay $\$ 11$ to eliminate a risk that poses an expected loss of $\$ 10$. The damages measure proposed above does not account for this possibility and consequently overstates the measure of full compensation (by using $\$ 11$ as a proxy for the expected value of the injury rather than \$10). However, the damages measure could easily be altered to reflect this possibility. If, for example, studies show that risk-averse individuals incur a cost of bearing risk equal to $10 \%$ of the expected value of the injury, then the jury's assessment of $E(p)$ could be reduced to reflect this cost. For example, a jury determination that $E(p)$ is $\$ 11$ would be reduced to $\$ 10$ and the damages award would then be based on $\$ 10$.

121. This is the way in which Judge Posner justifies a damages measure identical to the ex ante full-compensation award. See POSNER, supra note 18, at 199 (explaining how an individual's willingness to spend money to eliminate the ex ante risk of injury divided by the risk of injury yields a damages award that provides the correct level of deterrence).

122. For comparative purposes, the odds are 1 in 10,000 that a passenger will die in a plane crash ovcr the course of 100 flights. See Stephen Breyer, Breaking the Vicious Circle: Toward EFFECTIVE RISK REgulation 5 (1993).

123. This formulation of the damages question raises the issue of whether the amount of the plaintiff's wealth should be relevant to the jury's determination of the willingness-to-pay measure. 
figure of $\$ 2.50$, then the plaintiff's pain-and-suffering award should be $\$ 25,000$ ( $\$ 2.50$ divided by $1 / 10,000$ ).

As illustrated by this example, calculation of the $e x$ ante fullcoinpensation award requires information on the probability that an individual will suffer a pain-and-suffering injury of the severity suffered by the plaintiff. There often will be evidence on the probability that the product might cause the plaintiff some injury, particularly as this risk measure is central to a negligence determination. ${ }^{124}$ However, to compensate the plaintiff for the particular injury that she suffered, the ex ante fullcoinpensation award should be based upon the probability that the product might cause a pain-and-suffering injury of the severity that was in fact

Wealthier individuals are likely to be willing to pay more to eliminate a given risk of injury, which indicates that jurors should take the plaintiff's wealth into account when they detcrmine the willingnessto-pay measure. This implies that the award should be based upon what a reasonable person in the plaintiff's position would have been willing to pay to eliminate the risk.

There are reasons for rejecting an approach that attempts to account for the plaintiff's wealth level, however. Plaintiffs who are wealthy presumably get less utility from each dollar of damages than do plaintiffs who are less wealthy, yet the current system does not make the plaintiff's wcalth an explicit consideration in the pain-and-suffering damages calculation. See supra note 23 and accompanying tcxt. The plaintiff's wcalth is thus not a type of individual characteristic that the jury must neccssarily account for when it determines the ainount of fair compensation for a pain-and-suffering injury. This position is sensible since it would be hard for jurors to assess how an individual plaintiff's marginal utility of wcalth differs from that of the average person in the community. For this same reason, jurors would probably have a difficult time ascertaining how differenccs in wealth levels should affect willingness-to-pay measures. It is more likely that jurors would do well at determining how much a reasonable person (that is, one of average wealth in the community) would pay to eliminate the risk. Moreover, to the extent that it is unfair not to account for the plaintiff's wealth (because this omission means that wealthy plaintiffs may be undercompensated and poorer plaintiffs overcompensated), this unfaimess is mitigated by an unfaimess that the present system creates with respect to monetary damages. All consumers of a product pay the same premium for tort damages even though relatively poorer consumers are likely to reeeive less tort compensation for monctary losses such as lost wagcs and property damage. Because poorer consumers subsidize the insurance premiums of wealthier consumers for economic losses, it may not be unfair for poorer consumers to be somewhat overcompensated for noumonetary injuries at the expense of richer consumers, particularly since about half of all tort damages are for noneconomic losses. See supra note 10 and accompanying text.

For these reasons, I will assume that the award should be based upon what a reasonable person would pay to eliminate the risk of the pain-and-suffering injury, although as indicated above, the award could be based upon what a reasonable person in the plaintiff's position would pay.

124. A court applying the Learned Hand test for negligence would necd to eonsider whether the probability of harm multiphied by the magnitude of injury (the expectcd loss) is greater or lcss than the costs of precaution. See United States v. Carroll Towing Co., 159 F.2d 169, 173 (2d Cir. 1947) (Hand, J.). In addition, a negligence standard based on community norms of behavior is also likely to contain some consideration of the probability of injury,

because the proccss of developing a community norm involves arriving at a consensus as to what constitutes acceptable behavior. The required judgments of acccptability are made by inspecting those previous experiences to see how things turned out, all things considered. Actions that seem unncccssarily dangcrous in retrospcct would be just those that, viewed prospectively, present too high a combination of potential harm and probability, in light of the potential gains, to seern sensible.

Christopher H. Schroeder, Corrective Justice and Liability for Increasing Risks, 37 UCLA L. REv. 439, 463 n.100 (1990); see also CoLEMAN, supra note 13, at 358-59 (explaining why community norms often contain considerations of efficicncy). 
incurred by the plaintiff. It is doubtful that evidence establishing this risk value would be available for most cases.

The theoretical properties of the ex ante full-compensation award substantially mitigate this problem, however, since the willingness-to-pay ineasure, $E(p)$, changes with changes in the risk of injury, $p$. The award would not depend upon the underlying risk of injury if changes in the risk of injury changed the willingness-to-pay measure by a proportionate amount, since $M_{f}=E(p) / p .{ }^{125}$ Although this proportionality relationship will not hold for the entire range of risk values, it approximates what is likely to occur for the range of risk values that could plausibly be used in the damages calculation.

To understand this conclusion, it is necessary to understand why a change in the probability of injury might alter the damages award. In general, doubling the risk of injury does not necessarily double the willingnessto-pay measure, because the purchase of increasingly larger risk reductions makes the consumer poorer, "and this wealth effect diminishes his willingness to pay for further reductions."126 For example, a consumer who is willing to pay $\$ 10$ to eliminate a risk of 1 in 10,000 may be unwilling to double the willingness-to-pay measure to $\$ 20$ to eliminate a risk of 2 in 10,000 . Wealth effects might reduce this anount to something less than $\$ 20$, say $\$ 18$. Whereas the risk of 1 in 10,000 leads to an ex ante fullcompensation award of $\$ 100,000$ ( $\$ 10$ divided by $1 / 10,000$ ), the risk of 2 in 10,000 leads to an award of $\$ 90,000$ ( $\$ 18$ divided by $2 / 10,000$ ). In this case, by doubling the risk of injury, the ex ante full-compensation award is reduced.

Wealth effects accordingly imply that the ex ante full-compensation award will not increase, and may decrease, with increases in the risk of injury. However, significant wealth effects are likely to be present only when the pain-and-suffering injury significantly reduces the viction's marginal utility of wealth. ${ }^{127}$ Moreover, even for severe injuries of this type, wealth effects are unlikely to be a problem as long as the willingness-to-pay measure involves sums of money that are small in relation to individual wealth. Returning to the prior example, it is unlikely that the difference between $\$ 10$ and $\$ 20$ would create wealth effects sufficiently large to reduce the willingness-to-pay measure from $\$ 20$ to $\$ 18$. If there were no

125. Assume $p$ increases by $10 \%$ and $E(p)$ also increases by $10 \%$. Then, $M_{f}=(1+10 \%) E(p) /(1$ $+10 \%) p=E(p) / p$. Thus, in this case the award $M_{f}$ does not depend on the change in the underlying risk of injury.

126. W. Kip Viscusi et al, An Investigation of the Rationality of Consumer Valuations of Multiple Health Risks, 18 RAND J. Econ. 465, 468 (1987).

127. As the probability of injury increases, the insurance premium for the tort award increases. However, for severe physical injuries that reduce the victim's ability to enjoy money, the increase in the insurance premium causes a greater reduction in the individual's utility in the healthy state than it does in the injured state. To equalize utility across these states (as required by the definition of ex ante full compensation), the consumer must reduce the amount of the insurance policy (that is, the amount of full eompeusation), which reduces the insurance premium. See infra app. § 5A. 
wealth effects created by the change in risk values (so that the consuiner were willing to pay $\$ 20$ to eliminate a risk of 2 in 10,000$)$, then the ex ante full-coinpensation award would reinain $\$ 100,000$ ( $\$ 20$ divided by $2 /$ 10,000).

Thus, in theory, the award will be unchanged by increasing (or decreasing) the size of the risk to be eliminated if there are no wealth effects. This is likely to be the case for most tortiously caused injuries, since the range of risk values that can plausibly be used in the damages calculation encompasses sufficiently small levels of risk so that the willingness-to-pay measure involves small sums of money. The probability that an individual would suffer an injury of the particular severity suffered by the plaintiff cannot be greater than the probability that the product defect would cause an mjury of any severity. Hence the highest value that could be used in the damages calculation is the risk that the product defect would cause an injury of any type. As most product risks are very low, ${ }^{128}$ it follows that the willingness-to-pay measure will ordinarily be small.

Furthermore, although the defendant is the party that would benefit froin the use of inflated risk values $m$ the damages calculation (insofar as increased risk levels create significant wealth effects and thus reduce the willimgness-to-pay measure per unit of risk), practical reasons may prevent the defendant froin argumg for overly large risk values. Trial strategy, for example, could require that the defendant argue for low risk values in the

128. See, e.g., Peter H. Schuck, Rethinking Informed Consent, 103 YALE L.J. 899, 928 (1994) (asserting that "most [medical] treatment and product risks are quite low").

More generally, risk measures "are usually given as annual mortality rates, which are ncarly always smaller than $[1$ in 1,000]." Bernard L. Cohen \& I-Sing Lee, A Catalog of Risks, 36 HeAtTh Physics 707,707 (1979). For example, there is an annual risk of 1 in 11,000 that an individual will die from an accident in the home. See W. KIP VIScusi, Smoking: Making the RiskY Decision 24 (1992). The risk of death on the job is of a similar magnitude. See Michael J. Moore \& W. Kip Viscusi, The QuantityAdjusted Value of Life, 26 EcoN. INQUIRY 369, 371-376 \& tbl. 11 (1988) (showing annual fatality risk in 1976 of 5.89 per 100,000 for sample consisting of nonfarm household heads who were not selfemployed and who worked more than 20 hours a week in industries for which the Bureau of Labor Statistics gathers death statistics). The risk of death from a product-caused injury is only a suhset of all injuries in the home or on the job, however, and so it is difficult to determine that measure. See Schuck, supra, at $928 \mathrm{n} .120$. The data are better with respect to medical injuries. One empirical study yields the conclusion that hospitalized patients face a 3 in 10,000 risk of serious injury or death from medical malpractice. See id. at 928 n.120 (citing Paul C. Weiler et al., A Measure of Malpractice 35, 43 (1993) and discussion with Professor Weiler as to the most accurate measure of the risk of serious injury).

It is also instructive to look at traffic accidents, since "[a]ccording to data for the year 1988, motor vehicle accidents are the leading cause of accidental dcath for individuals younger than 78 years." Bureau of Transportation Statistics, U.S. Dep't of Transportation, Transportation Statistics: AnNual Report 1994 134. According to data for 1992, for every 100,000 vehicle miles, the risk of a fatal accident for passenger cars is 1.3 in 1,000; for trucks it is 1.4 in 1,000 ; and for motorcyclcs it is 25.1 per 1,000. See id. at 137, tbl. 6-7.

Of course, many cases will not involve fatalitics or severe injuries, thus making it more likely that the risk of such injuries will be much larger than a risk of 1 in 10,000. However, the reduced severity of injury reduces the willingness-to-pay measure, see infra app. $\$ 5 \mathrm{~B}$, and so risk measurcs for such injuries that are substantially ligher than 1 in 10,000 are unlikcly to involve significant wealth effects. 
context of pain-and-suffering damages, since reliance upon high risk values may undercut the defendant's arguments that it was not negligent.

On the other hand, care inust be taken to avoid probabilities that are so small that they cannot be properly evaluated by jurors. Studies liave indicated that individuals are unable to evaluate consistently and accurately probabilities sucl as 1 in $1,000,000 .^{129}$ Consequently, a damages calculation based on an extremely low probability number is likely to result in such a large degree of inaccuracy as to render the calculation unduly speculative for damages purposes. The 1-in-10,000 figure used in the example above is more defensible, although a higher figure such as 1 in 1000 could and should be used if studies show this is the smallest risk level that can be accurately assessed by individuals. ${ }^{130}$

There are, then, both lower and upper limits on the risk of injury that either party could plausibly use in the damages calculation. Presumably, the evidence will often be insufficient to establish a particular value within this range as the true risk of injury. Nevertlieless, as long as the risk values that could be used in the damages calculation are small, the choice of a particular value within this range is unlikely to create wealth effects that would significantly distort the dainages ineasure. ${ }^{131}$ Thus, the inethod used to derive the ex ante full-compensation award should lead to reasonably accurate results for a wide range of cases despite the lack of evidence on the true probability $p$ that an individual might incur an injury of the severity suffered by the plaintiff.

Moreover, complete accuracy is not required since a reasonable amount of uncertainty is permitted in damages calculations. ${ }^{132}$ That the $e x$ ante full-compensation award satisfies this general rule is best illustrated by comparing this estimation procedure to the method that courts have accepted for the calculation of tort damages for lost-earning capacity.

129. See VIScusi, supra note 91 , at 70.

130. Compare Schuck, supra note 128 , at 929 n.121 (citing a letter from Kip Viscusi, which states that "[o]ur studies suggest people do a horrible job of making decisions with respect to risks on the order of 1 in a million, but once we get to a denominator in the range of 10,000 their responses start to make sense.") with Cohen \& Lee, supra note 128, at 707 ("[T] here is good evidence that the public recognizes little difference between an annual risk of $[1$ in $10,000,1$ in $10,000,000$, and 1 in $10,000,000,000] . ")$. This point suggests that in giving jurors a probabihity such as 1 in 10,000 from which they should compute the damages award, it would be nseful to also provide them with a risk measure (for example, the risk of suffering a fatal injury in the home) that would help them to understand what a risk of this magnitude means. Compare supra note 122 and accompanying text.

131. See infra app., § 5a. See also Calfee \& Rubin, supra note 13, at 387 (wealth effects become significant only when the risk is 'large' say .02 or more, and the loss is something victims wish very much to avoid."); Cohen, supra note 18 at 328-31 (arguing that there will be no wealth effects for probability up to 1 to 1000 regarding the risk of death); Viscusi \& Evans, supra note 89, at 372 (describing empirical study of nonfatal risks finding that "[t] base level was not... great").

132. See, e.g., Story Parchment Co. v. Paterson Parchment Paper Co., 282 U.S. 555, 563 (1931) ("[I]t will be enough if the evidence show the extent of the damages as a matter of just and reasonable inference, although the result be only approximate."). See generally 4 HARPER ET AL., supra note 19, $\S 25.3$, at $509-10$. 
Particularly instructive in this regard is Saul Levmore's forceful description of the "mind-boggling series of issues and experts" that juries need to confront in assessing these damages. ${ }^{133}$ When the tort award includes compensation for losses to be incurred in the future, it is necessary to compute the present value of these future losses. ${ }^{134}$ " $[\mathrm{A}]$ small percentage difference in the discount rate will have enormous impact on more extensive recoveries that involve discounting over many years,"135 and yet the discount rate depends upon a variety of factors that are extremely difficult to predict. ${ }^{136}$ Any variations in the ex ante full-coinpensation award that are caused by data limitations appear to be acceptable when compared to variation in awards caused by data limitations in other tort damages calculations. ${ }^{137}$ Indeed, there is no reason to suspect that the data himitations inherent in the ex ante full-compensation method are any more pronounced than the data limitations inherent in the other methods that jurors currently use to compute paim-and-sufferimg awards. ${ }^{138}$

\section{B. Harmonizing the Ex Ante Full-Compensation Measure with Case Law}

Because there are a number of different ways of determining the amount of full compensation for a nonmonetary injury, it is necessary to sliow thit the ex ante full-compensation award provides a damages ineasure that is consistent with prevailing legal standards. As shown below, not only is the ex ante full-compensation award consistent with judicial rulings on how pain-and-suffering damages shonld be computed, but it can also be justified on the ground that it promotes the objectives of the tort systen.

\section{The Use of Mathematical Formulas for Computing Pain-and- Suffering Damages}

The ex ante full-compensation award at first glance appears to violate the rule im many jurisdictions that pain-and-suffering damages cannot be

133. Saul Levmore, Self-Assessed Valuation Systems for Tort and Other Law, 68 VA. L. Rev. 771, 795-810 (1982).

134. See, e.g., Chesapeake \& Ohio Ry. Co. v. Kelly, 241 U.S. 485, 489-91 (1916).

135. Levmore, supra note 133 , at 798.

136. Id. at 795-802.

137. Others have reached the same conclusion with respect to the current, open-ended approach for determining pain-and-suffering injuries:

Even though the testimony employed to determine future wage loss uses the rhetoric of dollars and cents and statistics, the trier of fact is actually being asked to predict how long a plaintiff will live, what jobs he would have held and what salaries he would have received if not for the injury. When one contemplates this task in the context of the wrongful death of a child, its crystal-ball gazing nature is obvious. Damages for intangible injuries, although admittcdly difficult to quantify, appear no less justifiable on that basis alone than damages for loss of future wages.

Ingber, supra note 16, at 779-80 (footnote omitted); see also Peter A. Bell, The Bell Tolls: Toward Full Tort Recovery for Psychic Injury, 36 U. FLA. L. REv. 333, 355-56 (1984).

138. See supra note 23 and accompanying text. 
quantified with the use of mathematical formulas. ${ }^{139}$ Judicial resistance to the use of formulas, however, appears to be based on the lack of an objective standard for measuring the severity of a pain-and-suffermg injury. Consider the following passage by the New Jersey Supreme Court in Botta v. Brunner, ${ }^{140}$ an opinion often relied upon by other courts in rejecting the use of mathematical formulas for computing pain-and-suffering damages: ${ }^{141}$

[T] here is no mart where the price of a voluntary subjection of oneself to pain and suffering is or can be fixed. It has never been suggested that a standard of value can be found and applied. The varieties and degrees of pain are almost infinite. Individuals differ greatly in susceptibility to pain and in capacity to withstand it. And the impossibility of recognizing or of isolating fixed levels or plateaus of suffering must be conceded. ${ }^{142}$

A formula that attempts to quantify the severity of the plaintiff's painand-suffering ijury would be difficult to defend, as there is no objective way to measure the severity of these injuries. ${ }^{143}$ The formula that yields the ex ante full-compensation award does not, however, quantify the plaintiff's pain and suffering in this sense. Instead, jurors determine the severity of the pam-and-suffering imjury. The willimgness-to-pay measure merely enables jurors to translate their injury assessment imto a monetary award. The method used to compute the ex ante full-compensation award should thus be permissible even in those jurisdictions that have rejected the use of mathematical formulas for computing pain-and-suffermg damages. ${ }^{144}$ Not surprismgly, courts that allow the use of formulas rely upon reasoning that would justify the use of the ex ante full-compensation formula. ${ }^{145}$

139. See Pearson, supra note 24 , at $944-45$.

140. 138 A.2d 713 (N.J. 1958).

141. See Beagle v. Vasold, 417 P.2d 673, 677 (Cal. 1966) ("[E]very decision since Botta holding [per diem] argument to be improper has followed, at least in part, the reasoning employed in that case.").

142. Botta, 138 A.2d at 718-19. New Jersey now allows the use of per diem arguments "without reference to a specific sum." New Jersey Rures of Court 1:7-1(b) (1995).

143. See supra note 21 and accompanying text.

144. Courts that have rejected the use of per diem arguments typically have given the following reasons:

(1) per diem arguments have no basis in the evidence since it is improper to permit witnesses to testify as to the value to be assigned to the plaintiff's pain and suffering; (2) they invade the province of the jury; (3) they lend a false air of certainty to an area where none exists since pain and suffering, by its very nature, is not subject to mathematical computation and is not capable of being exactly and accurately determined; and (4) they result in excessive verdicts. Pearson, supra note 24, at 945 . The first three reasons do not apply to the ex ante full-compensation award. The fourth reason, the concern about excessive verdicts, requires some concept of an adequate award. As argued below, the ex ante full-compensation award provides the appropriate measure for compensation, and so courts should not reject it on the grounds that the approach might result in inappropriate awards. See infra Part V.B.2.

145. Courts that have allowed the use of per diem arguments have relied upon the following reasons:

First, if it is permissible to state the total figure sought for pain and suffering, it is no more speculative to state the per diem figure, and the plaintiff should have the right to explain the 
Although one might argue that courts which have rejected the use of willingness-to-pay neasures to coinpute "hedonic damages" in wrongful death actions ${ }^{146}$ will also reject the method used to compute the ex ante full-compensation award, there is a nuajor distinction between the two approaches. Hedonic damages are usually determined on the basis of expert testiunony. Since there is no way to quantify the severity of the pain-andsuffering injury, jurors do not need expert testimony on hedonic damages to assess the severity of the plaintiff's injury. Furthermore, expert testimony regarding hedonic damages relies upon value-of-life studies that establish the average cost of injury within a population of individuals, ${ }^{147}$ which is not necessarily relevant or helpful for a jury. Rather, the jury nuust nuake an individualized danuages determination that would fully compensate one particular individual, the plaintiff. As a result, courts have rejected expert testimony regarding hedonic dainages. These concerns, however, are not inuplicated by the proposal developed here, because the ex ante full-compensation nethod allows jurors to evaluate the plaintiff's pain and suffering and only provides jurors with a method for translating that assessnent into the appropriate inonetary award.

The argument that the ex ante full-conipensation award is consistent with current case law is reinforced once we recognize that adopting this damages ineasure need not alter the nature of the evidence that jurors currently use to assess pain-and-suffering damages. "The traditional proof focuses on the specific individual who has been harmed, and on testiniony concerning the personal impact of the loss on the given individual."148 Such evidence would be central to the jury's determination of the ex ante full-conipensation award, since mcreases in injury severity will increase an individual's willingness to pay to eliminate the risk of injury. ${ }^{149}$ As a general rule, counsel is permitted to suggest to the jurors all reasonable inferences that they nay draw from the evidence so long as they understand that

\footnotetext{
components of the lump sum. Second, a mathematical formula is just one way to aid a juror in making a reasonable award, and the jury should not have to make a blind guess. Third, since there is no real yardstick to measure pain and suffering, use of a mathematical formula cannot be said to mislead the jury. Moreover, since defense is free to name its own figure, the defense will not be prejudiced by the plaintiff naming a figure derived through a formula. Fourth, a mathematical formula has been considered an illustration and not evidence. The defense can either refute the use of the formula altogether or use its own formula to argue for a lower figure. Fifth, even if the jury might be misled by per diem arguments, cautionary instructions by the judge can ensure fair decisions. ... Sixth, if an excessive jury verdict does oceur, trial or appellate review is available so that the amount of damages awarded can be lowered.
}

Jeffrey O'Counell \& Theodore M. Bailey, The History of Payment for Pain \& Suffering, 1972 U. ILL. L.F. 83, 105-06 (footnotes omitted); see also Pearson, supra note 24, at 945.

146. See Tabacchi, supra note 28 , at $339-41$.

147. See supra note 31 and accompanying text.

148. William J. Gillen \& Bruce A. Olson, Economic and Legal Defenses Against Claims for Hedonic Damages, For tHe DeF., Jan. 1991, at 18, 19; see also Jack H. Olender, Proof and Evaluation of Pain and Suffering in Personal Injury Litigation, 1962 Duke L.J. 344, 367-76.

149. See infra app. § 5B. 
the argument of counsel is not evidence. ${ }^{150}$ After presenting evidence regarding injury severity to the jurors, an attorney (or perhaps an expert witness) should be able to explain to jurors how to coinpute the ex ante fullcompensation award, as it is a reasonable way for jurors to determine these dainages based on their assessment of imjury severity. Hence the ex ante full-compensation award for pain and suffering could be implemented in the courts without requiring a change in the current law.

\section{Justifying the Ex Ante Full-Compensation Award as an Appropriate Measure of Full Compensation}

The ex ante full-compensation award provides one measure of full compensation. Other methods for determining the damages award are available, and presumably those methods will yield different measures of damages. ${ }^{151}$ For this reason, it is necessary to show that the measure of full compensation provided by the ex ante full-compensation award would be acceptable to the courts. This showing is particularly important because, in rejecting the use of value-of-life studies for computing hedomic damages, some courts have also questioned whether an appropriate ineasure of full compensation can be obtained from a willingness-to-pay measure:

[S]pending on safety items reflects a consumer's willingness to pay to reduce risk, perhaps more a measure of how cautious a person is than how much he or she values life. Few of us, when confronted with the threat, "Your money or your life!" would, like Jack Benny, pause and respond, "I'm thinking, I'm thinking." Most of us would empty our wallets. Why that decision reflects less the value we place on life than whether we buy an airbag is not immediately obvious. ${ }^{152}$

These observations by the Seventh Circuit suggest that an award that fully compensates an injury should depend ouly upon the injury rather than the context in which it occurs. The logic supporting this position seems to be unassailable: Spending money to purchase air bags or to satisfy the demands of an armed robber are different methods of protecting one's life, so why is the first measure more defensible than the second given that fully compensatory tort damages are supposed to compensate for the injury, which does not change in these two contexts?

The problem with this argument is that it mistakenly assumes that a fully compensatory paim-and-suffering award should equal the value of the

150. See 75A AM. JUR. 2D Trial § 554, at 133 (1991).

151. See McCaffery et al., supra note 17 (describing study showing that different ways of thinking about full compensation for pain and suffering yield significantly different awards).

152. Mercado v. Ahmed, 974 F.2d 863, 871 (7th Cir. 1992); see also Livingston v. United States, 817 F. Supp..601, 606 (E.D.N.C. 1993) (finding expert testimony on value of life derived from willingness-to-pay studies is inadmissible because it "is better characterized as measuring the value of avoiding risk," not the value of life). 
injury, since presuinably the value of an injury is independent of the context in which the injury occurs. The courts, however, routinely instruct juries that full compensation for pain and suffering is not equivalent to the value of the injury. ${ }^{153}$ This instruction is correct for a number of reasons, such as the fact that it is often impossible to value nonmonetary injuries in terins of inoney. For example, we would not say that a tort award for the loss of a victim's arm equals the value or worth of that person's arm. Indeed, the value of body parts or functions may not even be capable of being appropriately expressed in monetary terins; the two may be "incommensurable."

How can the ex ante full-compensation award, or any other inonetary measure of pain and suffering, be defended if paim-and-suffering injuries are not always commensurable with money? The reason is that even though it may not be possible to value physical injuries in terins of money, it does not follow that there is no way to determine the appropriate relationship between the severity of the plaintiff's injury and the amount of money damages that the defendant should pay as full coinpensation for that injury. ${ }^{154}$ To understand this point, we need to consider nore carefully what it might mean to say that something, such as a physical imjury, cannot be appropriately valued with money. The following observation by Cass Sunstein provides a useful starting point:

We should distinguish between cases in which a nonetary offer is entirely inappropriate ... and cases in which the inonetary sum, while appropriately offered, does not reflect a full or fully accurate valuation of the item in question. Artists, actors, and teachers might well believe that dollar sums cannot truly reflect the social value of what they produce-certainly in the sense that money is not valued in the same way as art or education-without believing that monetary compensation is itself inappropriate. ${ }^{155}$

Distinguishing between these two cases helps to unpack the meaning of the statement that physical injuries cannot be appropriately valued with money. Undoubtedly, part of our resistance to equating inoney with physical injury is based on the notion that in many contexts it is not appropriate

153. See, e.g., Fifth Circuit Pattern JuRy Instructions, supra note 23, $\S 15.4$ ("You are not trying to determine value, but an amount that will fairly compensate the plaintiff for the [pain-andsuffering] damages he has suffered.'); Eleventh Circumr PATTERN JURY lNSTRUCtions, supra note 23, $\$ 2.1$ ("[1]t is not value you are trying to determine, but an amount that will fairly compensate the Plaintiff for the [pain-and-suffering] damages he has suffered.").

154. See Cass R. Sunstein, Incommensurability and Valuation in Law, 92 MrcH. L. Rev. 779, 793

(1994). Sunstem argues that:

those who believe that goods are valued in different ways need not reject the possibility of rational clioice or even some form of trade-off among them. On the contrary, believers in diverse kinds of valuation would do well to insist that cloices occur and that they might well be judged rational or not. People clioose among differently valued goods all the time, and these choices are not immune from evaluation on rational grounds.

Id. (footnote omitted).

155. Id. at 788 . 
to exchange money for physical injury. It would not be appropriate, for example, to attempt to buy someone's arm for a sum of money. Why, then, is it permissible for the defendant to "buy the plaintiff's arm" through the payment of tort damages? At least part of the reason is that the defendant did not know for certain that the plaintiff would be injured (otherwise, punitive damages would be im order), so that the defendant did not act as if she were taking the plaintiff's arm in exchange for money. Rather, the situation is one in which the defendant tortiously created a risk that caused injury to the plaintiff's arm, and the payment of monetary damages is the way the defendant compensates the plaintiff for this exposure to risk and resultant imjury.

Nevertheless, money and physical injury inay continue to be incommensurable because the award does not, as Sunstem puts it, "reflect a full or fully accurate valuation of the itein in question."156 However, exchanges occur frequently-the artist selling her art-in which the monetary payment does not fully refiect the value of the object being exchanged. We do not necessarily conclude, though, that such exchanges are inadequate (or inappropriate) because of this incommensurability. Rather, insofar as we are willing to say that the amount of inoney is an adequate or acceptable excliange for the art, it is because in this context the artist was willing to accept this particular transaction-money for art. Similarly, even if the tort award does not reflect the full value of the plaimtiff's injury, it does not follow that the plaintiff has not been adequately or fully coinpensated for the injury. Instead, we may be willing to say that the damages award fully compensates the plaintiff because that award reflects the exchange--money for exposure to a risk of imjury - that would have been acceptable to the plaintiff given the context in which the risk exposure occurred. The ex ante full-compensation award reflects that exchange, whicl is why it can fairly coinpensate the plaintiff even though the award may not fully reflect the value of the injury caused by the risk in question.

The ex ante full-compensation award does not provide an injury "value" in the sense that the award is fungible or commensurable with the injury, because the ex ante approacl defines full compensation as the ainount of money that at the time of risk exposure equalizes the individual's utility across the potential states of her well-being (the injured and noninjured states). The risk exposure affects the individual's well-being in the healthy state due to the cost of imsuring against the injury threatened by the risk, and so this measure of full coinpensation depends upon the circumstances in whicli the risk exposure occurred whereas an injury "value" depends solely upon the injury itself. Hence the ex ante full-compensation award is consistent with instructions telling jurors that an amount that will fairly compensate the plaintiff for the injury is not equal to the value of the 
injury. ${ }^{157}$ Indeed, because the award is dependent upon the context in which the injury occurred, it is appropriate to say that the ex ante fullcoinpensation award provides a price for the pain-and-suffering injury, as prices are highly dependent upon the context of exchange. ${ }^{158}$

Relatedly the ex ante full-coinpensation award is also consistent with court holdings that the pain-and-suffering award should not be determined by asking how much money the victim would require in exchange for the certainty of suffering the injury that she in fact suffercd. ${ }^{159}$ By rejecting the certainty of injury as the basis for computing the dainages award, the courts are in effect instructing jurors to think of the injury in the context of a probabilistic chance of injury. Not only is the ex ante full-coinpensation award consistent with such an instruction, but it provides the most defensible way to calculate the dainages award by reference to a risk of injury, since the award is based upon the relationship between the plaintiff's injury and the risk which caused that injury.

157. See supra note 153 .

158. For these reasons, Margaret Jane Radin mischaracterizes the economic approach to calculating pain-and-suffering damages when she claims that

in this model there is an equation between the value of harm and the value of damages. . . .

I call this a commodified conception because it conceives of the harm to the injured

victim as commensurable with money, as if the victim's interest in being free of injury were

the same as money or a fungible commodity she possessed.

Radin, supra note 3, at 58-59 (footnotes omitted). As 1 have argued above, merely because the economic approach to calculating pain-and-suffering damages specifies an appropriate relationship between monetary damages and a risk of injury, such a relationship does not necessarily imply that money is commensurable or fungible with the injury as Radin claims.

It is understandable, however, why Radin has characterized the economic approach in this fashion, since economists often describe the results obtained from willingness-to-pay measures as providing a "value" for the injury in question. See, e.g., Viscus1, supra note 91, at 51 (entitling chapter "A Survey of Values of Risks to Life and Health"). The meaning of an injury "value" is subject to the interpretation that Radin gives it. However, when economists speak of injury values, "it is not meant to imply that society would willingly sacrifice the health or life of identified individuals for certain sums of money." Tolley et al., supra note 18, at 4. Given that the economic method assames that an individual's interest in being free of the certain risk of death is not fungible with the injury measure derived from "value-of-life" studies, it follows that the economic method does not require, as Radin asserts, that injury measures are always fungible with the injury itself. Rather, the economic method provides a price for the injury, which is an appropriate monetary measure for the injury only within the particular context in which the exchange (money for exposure to risk of injury) occurred.

159. See supra note 119. The analysis here provides a way to justify these rulings. Basing the damages award upon a choice of money for certain injury is likcly to yield an incorrect damages measure for the injury in question because that choice is unrealistie in a significant sense. If a serious injury were certain to occur, the individual might be willing to pay all of her wealth in order to avoid the injury. It is unlikely, however, that the individual would choose to forgo all of her wealth in order to purchase the product or service that creates the risk in question. Rather, the individual would probably choose not to purchase the good or service, as that choice would eliminate the risk without forcing the plaintiff to forgo all of her wealth. Thus, basing the damages measure on what the plaintiff would pay to eliminate the risk of a certain injury is unlikely to provide an award that appropriately reflects the price that the plaintiff put on the injury before facing the risk of suffering it. By contrast, when the risk of injury is quite small, it is much more plausible that the plaintiff would choose to purchase the product (and face the risk) since the cost of that risk will ordinarily involve small sums of money in relation to the plaintiff's wealth. 
In addition, considerations of corrective justice indicate that the damages award should be based upon the risk of injury. The defendant must pay for the plaimtiff's injury because the defendant is legally responsible for the risk that caused the injury. Accordingly, the risk of injury should also determine the damages that would compensate the plaintiff for the tortious conduct. ${ }^{160}$

Finally, the measure of full compensation provided by the ex ante fullcompensation award can be justified on deterrence grounds. The correct incentive for deterrence requires that manufacturers, in making their safety investments, account for the full cost of the injuries that their products might cause consumers. The ex ante full-compensation award provides the appropriate cost in this regard. ${ }^{161}$ Consequently, manufacturers that are liable in tort for the ex ante full-compensation award will face the correct safety mcentives. ${ }^{162}$

160. Christopher Schroeder has argued that ex ante correetive justice requires that risk-creating actors be liable for the expected harm caused by their activities. See Schroeder, supra note 124, at 46566. As I argue more fully below, the ex ante full-compensation award is consistent with this requirement. See infra Part VI.A.

161. See Calfee \& Rubin, supra note 13, at 390-91 ("A reasonable measure of the social cost of using a risky product is production costs . . . plus . . . willingness to pay to eliminate the risk.').

162. See PoSNER, supra note 121, at 199. Moreover, if manufacturers were hable for the ex ante full-compensation award, the product price under strict hability would accurately reflect the risk level posed by the product. A manufacturer that is held strictly liable for the ex ante full-compensation award will charge a premium no less than $p M_{f}=p E(p) / p=E(p)$. Strictly liable manufacturers in competitive markets will therefore sell their products at a price equal to the cost of production plus some amount at least equal to $E(p)$. The strict liability priee consequently reflects the full social cost of the product.

By contrast, John Calfee and Paul Rubin argue that tort awards for pain and suffering imply that prices under strict liability are too high and will deter efficient purchases: "A consumer who knows the probability and type of injury will purchase the product only if [the consumer's valuation of the product's benefits] is greater than the price plus what the consumer would be willing to pay to prevent the loss." Id. at 387. Price under strict liability already includes a charge for the insurance premium for the pain-and-suffering award, whicb we have just found is equal to $E(p)$. Thus, Calfee and Rubin conclude that "the effcct of strict liability is to require the consumer to pay nonpecuniary costs twice, once as expected injury, and again for worthless insurance, both measured as $[E(p)]$." Id. The problem with this argument is that the insurance is not "worthless" as Calfee and Rubin assert. As I have demonstrated, an award based on $E(p)$ provides full compensation to the consumer in an ex ante sense, so there is no reason for consumers to add an additional amount to the product's purcbase price to account for any uncompensated ex ante injury costs. Strict liabihity consequently does not cause consumers to pay twice for nonpecuniary injuries as Calfee and Rubin claim, and so tort awards for pain and suffering do not distort consumption choices in the manner that Calfee and Rubin depict.

Calfee and Rubin also argue against holding manufacturers strictly liable for pain-and-suffering injuries on the ground that such damages may deter the purchase of beneficial risk-reducing products, where the risk being reduced had previously been in the "background" and thus outside of the tort system. Id. at 392-98. Insofar as tort liability increases the cost of regulated risks relative to risks not being regulated, we would expect there to be some substitution towards the relatively lower cost (unregulated) risks. This implies that tort regulation will not necessarily lead to greater safety overall (a conclusion that follows dircetly from the theory of the second best), although it is possible that tort regulation will lead to greater safety. See Mark Geistfeld, Implementing Enterprise Liability: A Comment on Henderson and Twerski, 67 N.Y.U. L. REv. 1157, 1170-71 (1992). Thus, althougb Calfee and Rubin correctly point out that tort regulation may deter the purchase of some beneficial riskreducing products, it does not follow that tort regulation in the form of pain-and-suffering damages is necessarily inefficient. 
In sum, in addition to being consistent with case law, the ex ante fullcompensation award also proinotes the policies underlying tort awards for nonmonetary injuries, lending further support to the proposition that this award provides a measure of full compensation that should be acceptable to the courts.

\section{VI \\ The Measurement of Pain-And-Suffering Damages in Noncontractual Settings}

When the victim of the pain-and-suffering injury is not in a contractual relationship with the tortfeasor, a number of new considerations enter into the analysis of the appropriate tort award. Most significantly, outside of contractual settings, tort rules need not be justified solely on efficiency grounds. The appropriate ainount of compensation inay instead depend on principles of corrective justice. ${ }^{163}$ Because corrective justice requires that the victim be "Inade whole," a fully coinpensatory award for pain and suffering is necessary if the tort system is to achieve corrective justice. ${ }^{164}$ In addition, a victim who is not in a contractual relationship (such as buyerseller) with the injurer does not necessarily pay for the insurance provided by a tort award for pain and suffering. It may therefore be impossible to question the desirability of full compensation on the ground that such insurance provides inore coinpensation than is preferred ex ante by potential victims. Thus, the argument against full compensation for pain-andsuffering injuries has much less force for torts involving noncontractual relationships than it does for torts involving contractual relationships.

Although it is easier to justify fully coinpensatory awards for torts involving parties who are not in a contractual relationship, the measurability problein must still be addressed. Recall that courts have held that the damages ineasure cannot be derived by reference to the certainty of injury, ${ }^{165}$ which implies that the risk of injury must figure into the dainages calculation in soine inanner. One way to base the dainages calculation on the risk of injury is to rely on the ainount that an individual would accept in exchange for facing the risk of suffering that injury. Juries could calculate the pain-and-suffering award by first answering the following question: "What is the minimum amount of inoney that a reasonable person would have been willing to accept in exchange for facing a risk of 1 in 10,000 of ending up with an imjury as severe as the plamtiff's pain-and-suffering

163. Jules Coleman persuasively argues that the principles of corrective justice provide the best explanation for current tort practices outside of the products liability setting. See ColEman, supra note 13 , chs. $10-20$.

164. See Schroeder, supra note 124 , at 450 (arguing that if a tort doctrine is to satisfy the requirements of corrective justice, "victims must be made whole (compensated)"); see also ColemaN, supra note 13 , at $371-73$.

165. See supra note 119 and accompanying text. 
injury?" If, for example, the jury arrived at a figure of $\$ 2.50$ for accepting this risk, then the plaintiff's pain-and-suffering award should be $\$ 25,000$. Despite the appeal of this approach, the willingness-to-pay ineasure provides a more defensible basis for determining the damages award.

\section{A. Willingness to Accept Risk as an Appropriate Basis for Calculating Full Compensation}

To derive an appropriate ineasure of dainages, we inust account for the risk of injury in the damages calculation. As before, let $p$ represent the risk that an individual might suffer a paim-and-suffering mjury caused by a riskcreating actor. Let $A(p)$ be the minimum amount of money that a potential victim would be willing to accept in order to have the risk $p$ imposed upon her. By definition, $A(p)$ is the amount of money that from an ex ante perspective would leave an individual indifferent between the following two situations: (1) the individual is not exposed to the risk and receives no compensation for it; and (2) the individual is exposed to the risk but receives the payment $A(p)$ whether or not she is imjured. For this reason, it is clear that $A(p)$ would provide an appropriate measure of full compensation if risk-creating actors were to pay $A(p)$ to each potential victim whether or not these individuals were injured. Under this approach, potential injurers would be paying for the expected harm caused by their risk-creating activity and potential victims would be fully compensated for being exposed to the risk of injury. As such, this compensation scheme satisfies the demands of ex ante corrective justice. ${ }^{166}$

Good arguments can be made that the tort system should strive to achieve ex ante corrective justice for torts imvolving noncontractual relationships. ${ }^{167}$ This indicates that the measure of full compensation should equal $A(p)$, although this measure of full compensation is subject to the obvious criticism that potential injurers do not pay damages to each potential victim whether or not an injury occurs. Instead, the current system requires that an individual suffer an actual imjury before she can pursue a tort claim for compensation. ${ }^{168}$ Because potential victims receive no payments from risk-creating actors, a damages award equal to $A(p)$ would not fully compensate actual victims, the plaintiffs, within the current system. Moreover, because risk-creating actors are liable only if they cause injuries, a payment of $A(p)$ only to those who are injured would mean that potential injurers do not pay for the full cost of the expected harm created by their conduct. Indeed, the requirement that tort liability attaches only at the point

166. According to Christopher Schroeder, "corrective justice principles can be satisfied with a system that holds people liable for the expected harm of their actions, whether or not those actions cause harm." Schroeder, supra note 124, at 469.

167. See generally Schroeder, supra note 124.

168. See Prosser and Keeton on the Law of Torts $\$ 30$, at 165 (W. Page Keeton et al. eds., 1984). There are exceptions to this general rule. See id. $\S 54$. 
of injury indicates that the current system does not achieve ex ante corrective justice.

For this reason, Christopher Schroeder has argued that it would be more desirable if risk-creating actors were forced to pay for the increased risk of mjury that they impose on others, whether or not an injury actually occurs. ${ }^{169}$ These payments, which should equal $A(p)$ for each individual exposed to the risk, would be deposited in a fund, and individuals who suffer imjuries could then receive full coinpensation from the fund. ${ }^{170}$ The reform proposed by Schroeder has features that are attractive in principle. For example, why should risk-creating actors who fail to use reasonable care escape liability due to the fortuity that their conduct did not result in any injuries? Whether an injury occurs or not, the conduct is equally culpable, yet sometimes the actor pays nothing and other times it pays a great deal.

It may be possible to accommodate these concerns, however, without reforming the tort system in the manner proposed by Schroeder. The risk payment $A(p)$ is an appropriate measure of full coinpensation within a system that seeks to achieve ex ante corrective justice. Hence, awards for actual injuries that depend upon $A(p)$ may also be able to achieve ex ante corrective justice. To be more precise, although risk-creating actors do not make an actual payment of $A(p)$ to each person upon whom they have imposed a risk of injury $p$, the tort system imight provide the functional equivalent of such a compensation scheine if tortfeasors were required to make a damages payment of $A(p) / p$ to those who incur injuries.

To understand this point, assume potential victins can purchase a fully compensatory insurance policy. Given a known risk of injury $p$, the inaximum amount that an individual would spend each period on the insurance premium implicitly defines the imsurance payout that would fully compensate her for the injury. This premium cannot exceed the amount $A(p)$ that she receives each period for the risk exposure. (Spending more than $A(p)$ for insurance would not inake sense, as the individual would be better off by not facing the risk and eliminating the need for insurance). Thus, the mdividual would never accept a risk payment of $A(p)$ that is less than the premium for a fully compensatory insurance policy. Since $A(p)$ is the minimum amount of money that the individual would accept to face the risk, this risk payment cannot exceed and inust therefore be equal to the premium for a fully compensatory insurance policy. If such a policy were priced at the actuarially fair premium of $p M_{f}$, then $A(p)=p M_{f}$, and so $M_{f}=$ $A(p) / p$.

A tort award equal to $A(p) / p$ would thus fully compensate the individual for the pam-and-suffering injury, where full coinpensation is defined by reference to an ex ante perspective that depends upon the risk that caused

169. Schroeder, supra note 124 , at 469 .

170. Id. at $468-69$. 
the injury. Moreover, even though individuals receive coinpensation only when injured, the guarantee of the tort award (a fully compensatory insurance policy against the tortious risk) is functionally equivalent to the receipt of the risk payment $A(p)$ (insurance premium) in each period. This damages award accordingly satisfies the requirement of ex ante corrective justice that individuals be "inade whole" in each period for the risk imposed upon thein. ${ }^{171}$

Holding a defendant liable for this amount of damages would also yield an efficient level of deterrence. If the defendant were liable for an amount $A(p) / p$, then a risk-creating actor's expected liability costs would be $p(A(p) / p)=A(p)$, which is the cost of the risk created by the conduct in question. This damages ineasure thus gives risk-creating actors an incentive to take efficient safety measures.

This damages measure would not satisfy the requirements of ex ante corrective justice if the risk-creating actor did not incur actual liability costs in each period equal to the expected harm created by its conduct. This would not be a problem if risk-creating actors purchased liability-insurance policies, since this would force most of them to pay premiums each period no less than their expected liability costs of $p(A(p) / p)=A(p) .{ }^{172}$ These actors do in fact pay in each period for the expected harm caused by their risk-creating activity whether or not such harm actually occurs, thereby satisfying this requirement of ex ante corrective justice.

Consequently, if this damages measure were adopted for torts involving noncontractual relationships, it is quite plausible that the tort system could achieve ex ante corrective justice in most cases even though tort liability attaches only at the point of injury rather than the point of risk creation. Moreover, an award of $A(p) / p$ provides full compensation based on the risk of injury, satisfying the requirement that compensation not be based on the certainty of injury. ${ }^{173}$

171. The fact that the prospect of a tort award (insurance policy) given to potential victims cannot be exchanged in any period for its monetary equivalent (the per-period premium) may indicate that potential victims are not receiving the functional equivalent of an actual payment of $A(p)$ per period. An altemative way to conceptualize the situation in terms of ex ante corrective justice is to view the exchange as one in which risk-creating actors give potential victims a lottery ticket whicl provides a monetary benefit that exactly offsets the risk of injury.

172. Policyliolders would always pay premiums equal to $A(p)$ in each period if their insurance premiums were actuarially fair. However, insurance premiums ordinarily are not actuarially fair because insurance companies must charge for administrative expenses. Nevertheless, if all policyliolders create equal risks, they will pay premiums in each period in excess of the expected harm caused by their risk-creating activities. The only situation in which a risk-creating actor with insurance might pay premiums less than $A(p)$ is one in which all policyholders pay the same premium even though some of them crcate a higher risk of injury. Here, the low-risk policyholders are subsidizing the highrisk policyholders, and thus it is possible that the high-risk policyholders will pay less than the expected cost of the liarm created by their risk-creating conduct.

173. See supra note 119 and accompanying text. 


\section{B. Practical Considerations: $A$ Comparison of Willingness to Accept Risk with Willingness to Pay to Eliminate Risk}

Although an individual's willingness to accept risk provides an appropriate basis for determining the ex ante full-coinpensation award for torts involving noncontractual relationships, we must still determine whether this dainages calculation is feasible since juries inay not have access to accurate evidence regarding the probability that an individual would suffer a painand-suffering injury equal in severity to that of the plaintiff.

In evaluating the ex ante full-compensation award for torts involving contractual relationships, which is based on the ineasure $E(p)$ of the individual's willingness to pay to eliminate the risk, we found that the difficulty of ascertaining the true risk of injury is unlikely to have a significant inpact upon the award because the range of risk values that could plausibly be used in the damages calculation (such as one in 10,000) should yield similar damages awards. ${ }^{174}$ In theory, these arguments regarding $E(p)$ apply to the willingness-to-accept ineasure $A(p)$, as economists have shown that the two measures will often be virtually equivalent. ${ }^{175}$ However, a number of studies have shown that "froin an expected utility perspective, imdividuals generally place too high a value on preventing increases in a risk from its current level (the so-called status quo bias or reference risk effect)."176 As a result, willingness-to-accept measures are often two or more times as high as willingness-to-pay measures, ${ }^{177}$ which suggests that we cannot assume the willingness-to-accept ineasure $A(p)$ can be treated as if it were equivalent to the willingness-to-pay measure $E(p)$.

174. See supra text accompanying notes 124-131.

175. See Jack L. Knetsch, Legal Rules and the Basis for Evaluating Economic Losses, 4 INT'L Rev. L. \& ECON. 5, 6 (1984) (asserting that in principle, there is a "small and generally insignificant difference between the two measures"). Hcrbert Hovenkamp provides a good explanation of why any difference between the two measures is likely to be negligible:

[T]he fact that for most people money has declining marginal utility tends to make [willingness to accept] slightly larger than [willingness to pay]. Someone will generally be willing to pay less to have something than he would accept as compensation for giving up the same thing bccause the dollars in the first transaction come out of his current money income or savings, while the second adds to his income or savings. Under diminishing marginal utility of income, the money added to his wealth gives him less utility per dollar than the money he already has, so he would demand more in exchange. In general, however, effects produced by the dechning marginal utility of income will be shight unless the particular entitlement at issue is very large in relation to a person's wealth.

Herbert Hovenkamp, Legal Policy and the Endowment Effect, 20 J. LEGAL STud. 225, 225-26 (1991) (footnote omitted).

176. VIScusI, supra note 91 , at 151 .

177. A number of studies that have yielded these results are described in Elizabeth Hoffman \& Matthew L. Spitzer, Willingness to Pay vs. Willingness to Accept: Legal and Economic Implications, 71 WASH. U. L.Q. 59, 66-84 (1993). One recent study, for example, found that "for a nonmarket good with no close substitutes (i.e., reduced health risk), the [willingness-to-pay and willingness-to-accept] value measures diverge and persist, even with repeated market participation and full information on the nature of the good." Jason F. Shogren et al., Resolving Differences in Willingness to Pay and Willingness to Accept, 84 AM. Econ. Rev. 255, 266 (1994). 
Psychological studies have provided a generally accepted explanation for the divergence between these two risk measures. These studies have found that individuals evaluate gains and losses froin a reference point (the status quo). From this reference point, the aggravation imdividuals experience im suffering a loss is greater than the pleasure they derive from a gain of the same amount. ${ }^{178}$ Thus, how individuals evaluate something depends upon whether it involves a gam or loss. For example, in deciding how much money to pay for an item, the individual views the payment as a loss and receipt of the item as a gain. Now, if the status quo is changed so that the mdividual is selling the same item, then giving it up is a loss whereas the receipt of money is a gain. Even though the saine item is involved in both of these transactions, due to the different way that imdividuals evaluate gaims and losses, they will demand a higher selling price than they would be willing to pay to purchase the same thing.

This difference in the buying and selling prices for an identical item explains why individuals will demand much more money to accept a risk of physical injury (selling health) than they would pay to eliminate the identical risk (buying health). A recent study conducted by Edward McCaffery, Daniel Kahneman, and Matthew Spitzer affirms that there is likely to be a substantial disparity between the willingness-to-pay and the willingness-toaccept measures used to compute the ex ante full-compensation award. ${ }^{179}$ They used different jury instructions that correspond to buying and selling perspectives in order to determine whether individual determinations of full compensation for a given pain-and-suffering injury would differ depending on the instruction. One instruction captures the buying perspective inherent in the willingness-to-pay measure by defining the status quo as one in which the individual is already injured. Thus, the damages award in effect enables the plaintiff to buy happiness to compensate for the extant imjury. McCaffery, Kahneman, and Spitzer then captured the selling perspective inherent in the willingness-to-accept measure with an instruction that framed the status quo as one of health, so that the monetary damages award in effect represents the amount that the individual would accept in exchange for her health (by suffering the imjury). They found that the damages award yielded by the buying instruction is reduced by at least a half as compared to a damages award yielded by the selling instruction, which suggests that

178. See Knetsch, supra note 175 , at 8 (stating that a "substantial body of psychological tests" supports the reference-risk effect). The divergence between the willingness-to-pay and willingess-toaecept measures can also be explained on the ground that health cannot be perfectly exchanged for money. Standard microeconomic theory predicts that this "substitution effect" will cause a significant divergence between these two measures that is additional to the effect caused by wealth changes. See W. Michael Hanemann, Willingness to Pay and Willingness to Accept: How Much Can They Differ?, 81 AM. EcoN. REv. 635 (1991). Substitution and wealth effects do not appear to be sufficient to explain the divergence between the two measures, however, since it is not evident how they explain "certainty premiums." See infra note 180.

179. See McCaffery ct al., supra note 17. 
the willingness-to-pay measure $E(p)$ is likely to be inuch sinaller than the willingness-to-accept ineasure $A(p)$.

The divergence between the two risk ineasures indicates that the reference-risk effect will affect the jury's determination of $E(p), A(p)$, or both. Of inuch greater practical concern is the reference-risk effect on the willingness-to-accept ineasure $A(p)$. The reference point for the damages calculation based on the willingness-to-accept measure $A(p)$ is one of no risk. If the damages calculation were based on a risk of injury $p$ greater than its true value, then the prospect of loss would be inuch larger than it actually is. This inflated value for the prospective loss is likely to increase significantly $A(p)$ above what economic theory would predict (on the basis of wealth effects), yielding a damages award that inay be significantly higher in relation to what the award would be if it were based on the true value of the risk in question. Similarly, basing the damages calculation on a risk of injury lower than its true value inay result in a significantly deflated award. Consequently, the reference-risk effect is likely to render a painand-suffering award based on the willingness-to-accept measure $A(p)$ quite sensitive to the choice of $p$ (the risk that an individual would suffer a painand-suffering injury as severe as the plaintiff's injury).

By contrast, the willingness-to-pay ineasure $E(p)$ is less susceptible to the reference-risk effect. Although the same reasons that the reference-risk effect leads individuals to overvalue risk increases also lead thein to undervalue risk reductions, the reference-risk effect is diminished, if not eliminated, when the willingness-to-pay ineasure pertains to reducing a risk to zero. ${ }^{180}$ Because the ineasure $E(p)$ of the individual's willingness to pay to eliminate the risk is not significantly influenced by the reference-risk effect, the choice of the mitial risk value $p$ sought to be eliminated should not have a significant effect on the damages calculation. ${ }^{181}$

Due to the difficulty of obtaining good evidence on the true risk $p$ that an individual would suffer a pain-and-suffering injury equal in severity to the plaintiff's injury, damages awards based on the willingness-to-accept measure $A(p)$ inay be unduly speculative, which would lead courts to reject

180. See ViscusI, supra note 91, at 142-43. Studies have shown that "any given incremental risk reduction ... will be more highly valued if this reduction leads to zero risk than if it achieves only partial risk reduction, whereas standard economic models predict that the last incremental risk reduction should be less highly valued." Id. at 124 . For example, a risk reduction of $1 / 1000$ will be more highly valued by individuals if it results in the complete elimination of risk rather than a reduction in the overall risk level from $2 / 1000$ to $1 / 1000$. Becausc individuals are willing to pay more to achieve certain outcomes (the elimination of risk), the added amount is called the "ccrtainty premium."

Recall that the reference-risk effect causes individuals to undervalue risk reductions. The existence of certainty premiums implies that this undervaluing is less significant or nonexistent when the risk reduction eliminates the risk. For an explanation of why such behavior might be rational, see infra notes 184-185 and accompanying text.

181. This assumes that the risk values that could be used are small enough so that no wcalth effects are created by the choice of different risk values. See supra notes 127-132 and accompanying text (argning that the risk values that could plausibly be used in the damages calculation are unlikely to involve wealth effects). 
such awards. ${ }^{182}$ As a practical matter, then, the damages award may have to be based on the willingness-to-pay measure $E(p)$. This outcome might seem problematic because $E(p)$ is likely to lead to a much smaller damages award than $A(p)$. There are good reasons, however, for concluding that a damages measure based on $E(p)$ would yield a defensible measure of compensation.

\section{The Appropriateness of Using Willingness to Pay to Eliminate Risk as the Basis for Determining Damages Awards for Torts Involving Noncontractual Relationships}

There are at least two ways to justify a damages measure based on the willingness-to-pay measure $E(p)$ for torts involving noncontractual relationships. ${ }^{183}$ The first is that the measure $E(p)$ provides a better measure of the individual's preferred risk-dollar tradeoffs than does the willingness-toaccept measure $A(p)$. This is not to say that imdividuals are always rational when they evaluate $E(p)$ but somehow fall prey to irrational considerations when they assess $A(p)$. Rather, the assessment of $E(p)$ may simply be more accurate than the assessment of $A(p)$. As W. Kip Viscusi has shown, the reference-risk effect can be explained as a rational response to imperfect information. ${ }^{184}$ Consequently, an individual's evaluation of $A(p)$ can be rational, but an informational problem may cause this assessment to be higher (the reference-risk effect) than the amount that the individual would choose if there were no informational problein (and no reference-risk

182. See supra note 132 and accompanying text (explaining that the difficulty of achieving accurate measurement in damages calculations will bar recovery if the uncertainty is unreasonable).

183. In addition to the justifications provided below, one could also justify a damages measure based on the willingness-to-pay measure by assuming that potential victims in noncontractual settings are not entitled to be free of the risk in question. Such an approach is subject to the criticism that this "assumption is inconsistent with the belief in the personal integrity of each individual that lies at the foundation of the common law tort system." Jennifer H. Arlen, Reconsidering Efficient Tort Rules for Personal Injury: The Case of Single Activity Accidents, 32 WM. \& MARY L. REv. 41, 63 (1990). The contrary argument is that it is not always obvious who caused the risk of injury when two parties interact, so it is not always clear who owns the entitlement to be free of risk. The difficulty of choosing between a willingness-to-pay measure and a willingness-to-accept measure in the context of a negligence determination for noncontractual torts is discussed in Hoffman and Spitzer, supra note 177, at $106-12$.

184. Viscusi develops this point with what he calls "prospective reference theory," which is based on the standard expected utility model of microeconomics with the added assumption that individuals treat stated probabilities as imperfect information which is processed in a Bayesian fashion to update their prior probability estimates (the reference risk). See Viscusi, supra note 91, at 112, 114-19. According to Viscusi:

The framework is consistent with two possible scenarios. First, the individual may be legitimately suspicions of supposedly "hard" probabilities, particularly if he or she does not have full confidence in the experiment being performed. The second possibility is that this behavior may reflect an inherent aspect of individuals' information processing whereby individuals act as if risk information is imperfect. Thus, the functioning of individuals' cognitive processes may lead to this partial leaming phenomenon. Even under this second interpretation, however, the processing of the information and subsequent decisions [can] occur in a rational, Bayesian manner that is augmented by the role of reference risks.

Id. at 115. 
effect). By contrast, because it pertains to a situation of certainty (the elimination of risk), the willingness-to-pay measure $E(p)$ is not plagued by an informational problem (and thus not affected by the reference-risk effect). ${ }^{185}$ Absent informational problems, there may be no significant difference between a risk assessment based on either $A(p)$ or $E(p) .{ }^{186}$ Thus, one could justify using $E(p)$ as a proxy for $A(p)$ on the ground that a wellinformed evaluation of $E(p)$ more accurately reflects the individual's riskdollar tradeoffs than does an imperfectly informed assessinent of $A(p) .{ }^{187}$

Efficiency considerations provide a second justification for basing the damages measure on $E(p) .{ }^{188}$ Although there are obvious differences between the situation in which the imjurer and victim are in a contractual relationship and that in which they are not, the two situations share essential similarities relevant to an efficiency analysis of the pain-and-suffering award. In a contractual setting, the buyer accepts the risk of injury to receive the benefit of the risk-creating product or service. Any ex ante liability costs the seller incurs in offering the product or service are included in the price of the product or service. Tort compensation therefore is not a forn of free insurance for the buyer, which is why the amount of tort compensation should depend upon the buyer's willingness to pay for such insurance. Similarly, in noncontractual settings, tort rules often create an analogous set of costs and benefits for imdividuals, so that individuals in these settings would prefer that tort damages be based upon a willingnessto-pay measure.

This is because tort rules often operate in "bilateral risk" situations, in which individuals are both potential injurers and potential victims. In these situations, there is a significant change in the analysis of the costs and bencfits that tort rules create for individuals in noncontractual relationships. As Jennifer Arlen explains:

\section{Viscusi argues:}

The certainty situation is easier to process, so to the extent that reference points play a role because of cognitive limitations, they will be less prominent in this case. Similarly, if it is individuals' underlying distrust of the accuracy of probabilistic information that is the driving force behind reference effects, the introduction of certainty should eliminate these concerns. Id. at 116.

186. See supra note $\mathbf{1 7 5}$ and accompanying text.

187. The counterargument is that because health and money are not good substitutes, an individual's well-informed evaluation of $E(p)$ need not be approximately equal to a well-informed assessment of $A(p)$. See supra note 178. As such, even if informational problems cause individuals to estimate imperfectly $A(p)$, that estimate may be closer to the well-informed assessment of $A(p)$ than is a well-informed evaluation of $E(p)$ that significantly differs from the well-informed assessment of $A(p)$.

188. One can accept that tort rules in noncontractual settings should achieve corrective justice without rejecting the relevance of efficiency considerations. See CoLEMAN, supra note 13, at 358-59 (providing an account of corrective justice for noncontractual torts which recognizes that social norms regarding appropriate behavior will often involve considerations of economic efficiency). Moreover, under Coleman's account of corrective justice, the tort system is not compelled to implement corrective justice in every instance, so that tort rules could be constrained by efficiency considcrations. See $i d$. at ch. 19. 
Because each participant in a risky activity, such as driving a car, is a potential injurer as well as a potential victim, the principal benefit that the introduction of the tort system affords is not the promise of money damages for injuries suffered, but the ability to make a choice-presumptively rational and perfectly informed-to engage in an activity that otherwise would be prohibited [because it may injure others]. This benefit by itself inay be sufficient to fully compensate the participant for the risk that others impose on him; at the very least, it suggests that full-compensation damages may not be necessary im order for a tort rule to be [preferable $\mathrm{m}$ the individual's view]. ${ }^{189}$

These observations help to explain why the desirability of tort damages in bilateral-risk situations depends not only on an assessment of low an individual, as a potential victim, benefits from the prospect of receiving these damages, but also on an assessment of the cost that these damages impose upon the individual as a potential injurer. For this reason damages in bilateral-risk situations create the saine kinds of costs and benefits for individuals as those that are created in contractual settings. In both contractual and noncontractual settings, tort damages for pain-and-suffering injuries provide an ex ante benefit to individuals because these dainages are a form of insurance covering such injuries. This insurance, lowever, is not free. ${ }^{190}$ In contractual settings, the buyer pays for the insurance in the form of higher prices; in noncontractual settings, tort damages impose an ex ante liability cost on individuals whose activities subject others to the risk of injury. In both settings, then, if tort damages are set "too high," individuals may find it too costly to engage in beneficial, risk-creating activities. In that event, the loss that each individual experiences as a result of foregoing these activities may more than offset any benefit that tort damages provide to the individual in her role as a potential victim.

Because tort awards create similar sets of costs and benefits for individuals in both contractual and noncontractual settings, the analysis of the efficient pain-and-suffering award for contractual relationships applies to noncontractual settings involving bilateral risks. ${ }^{191}$ That analysis in turn shows that individuals may prefer tort damages for pam-and-suffering injuries to be based on the willingness-to-pay measure $E(p)$ rather than on the willingness-to-accept measure $A(p) .{ }^{192}$ Indeed, the public response to the

189. Arlen, supra note 183 , at 47.

190. Cf. 2 ALI STUDY, supra note 10, at 206 (noting that tort law can be conceived of "as a port of entry into an insurance program paid for and provided by members of the community for themselves") (emphasis added). For a discussion of how the costs of tort liability are distributed throughout different scctors of the community, see Alfred F. Conard, Who Pays in the End for Injury Compensation? Reflections on Wealth Transfers from the Innocent, 30 SAN Diego L. REv. 283 (1993).

191. This point is established more rigorously infra app., $\$ 6$.

192. There is one class of cases not necessarily covered by this analysis. Ultrahazardous activities subject to strict liability could create risks that are different in degree and in kind from the risks subjeet 
tort crisis of the 1980 s indicates that individuals might prefer a damages measure based on the willingness-to-pay measure $E(p)$. That crisis led virtually all of the states to enact reforms that reduce tort liability in order to reduce the costs of hability insurance. ${ }^{193}$ Support for these reforms can thus be partially explamed in terms of increased public recognition that tort rules not only benefit each of us (as potential victins), but also impose a cost upon us (as potential injurers and thus purchasers of liability insurance). ${ }^{194}$ This suggests that the annount of tort insurance that individuals prefer depends at least in part on how much they are willing to pay for it.

Consequently, there are strong reasons for concluding that the ex ante full-coinpensation award for torts involving noncontractual relationships should be based upon the willingness-to-pay measure $E(p)$. As a practical inatter, data limitations may render such a computation the only feasible option, but the award calculated in this manner becomes inuch more attractive once we recognize that it may in fact reasonably refiect the ainount of damages that would be preferred ex ante by individuals.

\section{VII \\ TORT REFORM RECONSIDERED}

The prior analysis has justified the ex ante full-compensation award for pain-and-suffering injuries because it would promote the tort system's objectives, would yield defensible results despite data limitations, and could be implemented under current law. It is still an open question, however, whether the ex ante full-coinpensation award should be preferred over alternative approaches.

\section{A. Comparing the Ex Ante Full-Compensation Award to the Current Approach}

Undoubtedly, for inany the issue of greatest practical importance is whether the ex ante full-coinpensation award is likely to increase awards over current levels. This outcome could occur if adopting this approach were to lead to an increase in the types of pain-and-suffering mjuries that

\footnotetext{
to negligence rules, indicating that such risks do not fall within the hilateral-risk model employed in the Appendix. However, Jennifer Arlen has developed an analysis not subject to this limitation which shows that fully compensatory tort damages are not necessary for efficiency in bilateral-risk situations. See Arlen, supra note 183, at 102-03; see also Jennifer H. Arlen, Liability for Physical Injury When Injurers as Well as Victims Suffer Losses, 8 J.L. ECON. \& ORGANIzATION 411 (1992) (explaining that optimal damage rules for strict liability with contributory negligence do not depend upon full compensation). Thus, insofar as a damages award hased on a willingness-to-pay measure undercompensates plaintiffs for these kinds of injuries, this undercompensation may be acceptable.

193. See supra note 5 and accompanying text.

194. Although there was public support for these tort reforms, it does not follow that the reforms were efficient, since the public is likely to underestimate the benefits of tort rules relative to the costs, thereby creating a bias for reforms that reduce tort liability. See Geistfeld, supra note 96, at 834-38.
} 
are compensable in tort, or an mcrease in the award level for those injuries currently compensable in tort.

With respect to the former issue, some commentators have expressed concern that the willingness-to-pay methodology "documents the financial value of 'intangible' losses, further justifying their inclusion in tort law."195 However, even if the ex ante full-compensation award solves the measurability problem, it does not follow that the range of compensable nonmonetary injuries should be increased. Consider cases involving wrongful death or those in which the victim is unconscious. ${ }^{196}$ The victim has clearly suffered a nonmonetary injury in the form of a loss of life's pleasures. ${ }^{197}$ But since the victin's marginal utility of wealth has been reduced to the nnaximum extent possible, the justification for pain-and-suffering damages is weakest for these injuries. ${ }^{198}$ Thus, independent of any probleins of measurement, these cases present the inost problematic situation for paim-andsuffering damages. Moreover, the justification for fully compensating those pain-and-suffering injuries currently compensable in tort depends in part on the fact that other pain-and-suffering injuries receive no compensation. ${ }^{199}$ Compensating the entire range of pain-and-suffering injuries therefore weakens the case for providing full compensation for any given injury. Accordingly, there are good reasons for the tort system to continue excluding such damages even if the measurability problem is solved by the method used to derive the ex ante full-compensation award.

To be sure, resolving the measurability problem may lead to an increase $\mathrm{m}$ the types of compensable nonmonetary injuries, but this is not a reason to reject the ex ante full-compensation award. If such injuries should be compensated at present but are not due to measurement difficulties, then resolving the measurability problem would result in an appropriate, rather than excessive, degree of compensation.

With respect to the latter issue of whether the ex ante fullcompensation award would be higher than current awards for those nonmonetary imjuries presently compensable in tort, there is at least one reason for expecting such an outcome. Cognitive decision theory has found that individuals will give stronger responses to questions if the response is measured in the sane units as the stimuli or question (the "compatibility

195. Bovbjerg et al., supra note 3, at 928 .

196. A number of jurisdictions do not allow pain-and-suffering damages if the plaintiff is not conscious. See, e.g., McDougald v. Garber, 536 N.E.2d 372 (N.Y. 1989).

197. See VIScusi, supra note 8, at 89-90 (noting that value-of-life studies yield estimates for the cost of fatal injuries that often exceed the victim's pure financial loss); supra text accompanying note 113.

198. Indeed, the arguments used earlier to show why a willingness-to-pay measure can be translated into a measure of full compensation do not apply to such cases. See infra app., § 4. There are ways to justify the translation of willingness-to-pay measures into a monetary valuation for these kinds of injuries, but these justifications raise a number of troubling questions. See Kornhauser, supra note 31.

199. See supra notes 105-117 and accompanying text. 
effect"). ${ }^{200}$ The study by McCaffery, Kahneman, and Spitzer found that this compatibility effect applies to pam-and-suffering damages. ${ }^{201}$ Presently this effect is not great because jury instructions do not frame the damages question in a manner that suggests how money should be related to physical injury. In contrast, the ex ante full-compensation method inforins jurors how the damages question (willingness to expend money on safety) is related to the appropriate monetary award and is thus subject to the compatibility effect. Consequently, the ex ante full-compensation method may increase awards relative to the current approach. On the other hand, the $e x$ ante full-compensation method may reduce awards in some cases by imposing a uniforin method of measurement that is likely to yield a lower damages award than other methods that juries might employ under the current open-ended approach.

Whether the ex ante full-compensation awards are ultimately higher or lower than current awards, it is not clear why either result should lead us to reject the ex ante full-compensation method. To reject the method for this reason would imply that the measure yielded by the ex ante full-compensation award is not the right one, or that jurors incorrectly evaluate paim-andsuffering damages when they are provided with a method that enables them to understand how they can determine a damages award that would fairly compensate the plaimtiff for a pain-and-suffering injury. I have already shown that the ex-ante full compensation award provides an appropriate measure of damages. ${ }^{202}$ The following shows that award levels at present are probably mappropriate due to the way in which jurors currently determine these awards.

Under the current approach, jurors are confronted with a question that is likely to be unfamiliar to them: How do you translate a nonmonetary injury already suffered by an individual into an appropriate monetary award? Presented with an injury that has no obvious monetary counterpart, jurors are told that there is no standard by which the award can be calculated except that the award should fairly compensate the plaintiff for the mjury. ${ }^{203}$ With relatively little guidance, jurors are left to their own devices, or their "enlightened conscience" as it is sometimes described. ${ }^{204}$ Lawyers then take advantage of the open-ended nature of the damages determination by using a wide variety of practices to argue for a pain-andsuffering award. ${ }^{205}$ The current system's open-ended approach therefore alınost ensures that jurors will use a number of different methods to determine the award.

200. See McCaffery et al., supra note 17.

201. Id.

202. See supra Parts V \& VI.

203. See supra note 23 and accompanying text.

204. Id.

205. See McCaffery et al., supra note 17. 
For example, confronted by an injury that has already occurred, it would be natural for jurors to think of the problem in terms of how much money the plaintiff would take in exchange for a certain injury. Although courts do not allow attorneys to make this suggestion to jurors, ${ }^{206}$ jurors are not always told that they should avoid thinking of the award in these terms. ${ }^{207}$ Besides, even if jurors were to reahze that the award should be based on the ex ante probability of imjury, they are not told how the risk relates to the appropriate award, or indeed, what risk values might be appropriate. Finally, even if jurors were somehow able to figure all of this out, how would they decide whether the award should be based on the willingness-to-accept measure or the willingness-to-pay measure? Given the range of possibilities and the lack of guidance, it is not surprising that studies have found that jurors do in fact use different methods and reach different outcomes in determining pain-and-suffermg awards. ${ }^{208}$ Since the way im which jurors think about the damages computation is likely to have a significant impact upon the amount of the award, ${ }^{209}$ there are obvious reasons for questioning the appropriateness of current award levels.

By contrast, the ex ante full-compensation award provides a uniform method for determining the award, thereby introducing a degree of procedural equity that is presently lacking. A uniform method of computing damages should also lead to greater uniformity in damages awards for plaintiffs with similar mjuries. Moreover, the ex ante full-compensation award requires jurors to answer a question of the type they face on a daily basis: How much money should be expended on safety measures? Because jurors will be familiar with the decision-making that is involved in answering such a question, they will likely feel more comfortable in answering it, a stark difference to the way in which the damages question is presently posed.

Of course, it will not ordinarily be obvious to jurors how a willingnessto-pay measure relates to the issue of full compensation, but the rationale for the approach can be explained to them. Explaining how the damages should be calculated has the added virtue of showing jurors and litigants that there is a way to rationalize a result that on the surface appears to be mcapable of rationalization. To be sure, due to the difficulty of measuring the severity of pain-and-suffering injuries, there will be variability in any inethod used to derive pain-and-suffering damages. But if jurors and litigants understand the rationale for the approach and recognize that they reg-

206. See supra note 119 and accompanying text.

207. See, e.g., Douthwaite, supra note $23, \S 6-17$. But see supra note 153 (quoting instructions that tell jurors that the pain-and-suffering award is not the "value" of the injury).

208. See supra Part II.

209. See supra notes $179-180$ and accompanying text. 
ularly make such decisions regarding their own lives, they will more likely see the outcome achieved by the process as fair. ${ }^{210}$

In sum, there are a variety of reasons for rejecting the current approach in favor of the method that yields the ex ante full-compensation award. Nevertheless, other reforms may yield better results than the ex ante fullcompensation award. At this point, despite my earlier criticism, ${ }^{211}$ schedules appear to be the reform that holds the most promise in this regard.

\section{B. The Ex Ante Full-Compensation Award and Damages Schedules: The Jury as Survey Mechanism}

The method for deriving the ex ante full-compensation award imtroduces procedural uniformity that should imcrease the degree of horizontal equity $\mathrm{m}$ the system. Thus, insofar as the appeal of schedules lies in their potential for increasing horizontal equity, there may no longer be a need for scheduling if courts were to adopt the ex ante full-compensation award. On the other hand, since there is no objective measure for the severity of a pain-and-suffering imjury, applying a uniform method for translating the jury's assessment of injury severity into a monetary damages award may not result in a sufficient degree of predictability. Because schedules provide such an objective measure (by injury category), there may still be a strong case for scheduling to supplant a uniform method, such as the one that yields the ex ante full-compensation award, for determining pain-andsuffermg damages on an individualized basis.

In the event that the adoption of the ex ante full-compensation award does not obviate the need for scheduling, we must decide how we should derive the sclieduled awards. There are three potential sources for the scheduled awards: the price that individuals place on physical injuries in market transactions; the price that individuals place on physical injuries in nonmarket (survey) settings; and prior jury awards of pain-and-suffering damages. Analysis of these alternatives indicates that if we want to resort to scheduling, the sclieduled awards should be based upon prior jury determinations of the ex ante full-compensation award for the injury category in question.

\section{Market Prices for Physical Injuries}

Many studies have attempted to determine the price individuals place on injuries in the context of actual market transactions. ${ }^{212}$ One type seeks

210. 'When the correct answer isn't known, citizens tend to evaluate legal decisions in terms of the apparent faimess of the procedures that produced them." MacCoun, supra note 3, at 167. This observation is consistent with a finding by Edward McCaffery,-Daniel Kahneman, and Matthew Spitzer that lay individuals who were provided brief motivational explanations for different methods of determining pain-and-suffering damages, ineluding a buying and selling method, felt that the methods were equally fair. See McCaffery et al., supra note 17.

211. See supra Part IlI.B.

212. For an excellent survey of these studies, see Viscusi, supra note 91, at 51-74. 
to determine the amount of money that individuals are willing to accept in exchange for facing an increased risk of injury. For example, a study by Michael Moore and W. Kip Viscusi atteinpted to determine the relationship between wages and the number of deaths in the industry per 100,000 workers. ${ }^{213}$ The study found that workers receive $\$ 43.40$ in additional annual wages (in 1981 dollars) for each additional death per 100,000 workers. The increased risk will on average result in one death in a population of 100,000 workers. Because this population required $\$ 4.34$ million in 1981 dollars ( $\$ 43.40$ multiphed by 100,000 ) as compensation for the risk that one of its meinbers would be fatally injured, the study yielded an estinate of $\$ 4.34$ million as the cost that this group associated with the loss of one life. ${ }^{214}$ This approach has also been utilized to determine the price that workers place on nonfatal injuries. ${ }^{215}$

A different type of market study attempts to determine injury prices by ascertaining how much individuals are willing to pay for a inarginal reduction in the probabihity of dying. Examples of such studies involve individual decisions to employ measures such as smoke detectors and seat belts that reduce the risk of dying. ${ }^{216}$

The strength of these kinds of studies is that they are based on individual risk choices in actual market transactions. However, using nnarket data to estimate the price that individuals place on mjuries also creates numerous problems, prinarily because the inquiry is limited by the kinds of inarket data that are available. For instance, because it is easier to obtain inarket data pertaining to inarginal changes in risk (such as the change in wages for a slightly more risky job), these studies typically estimate risk-dollar tradeoffs for marginal changes in risk. Reliance upon these studies thus makes it necessary to translate the marginal-risk measure into a measure of the total injury.

The translation from a marginal-risk nneasure into a price for the injury threatened by the risk is problematic. One approach, described above, assumes that the average individual willingness-to-pay measure (\$43.40) can be translated into a measure for a group ( $\$ 4.34$ million), and that the group measure in conjunction with the total injuries likely to be experienced by the group (one fatality) provides the appropriate price for the injury in question (\$4.34 million per life). This reasoning makes an unrealistic assumption that the price whicl a group places on the statistical chance of death of one of its menibers is equal to the price an individual places on her own life when confronted by a fatal risk.

213. See Michael J. Moore \& W. Kip Viscusi, Doubling the Estimated Value of Life: Results Using New Occupational Fatality Data, 7 J. Por'y ANALYsis \& Mamt. 476 (1988).

214. Id. at 486.

215. See VIScusi, supra note 91, at 61-63 (summarizing labor market studies that ascertain injury prices for nonfatal job injuries).

216. See id. at 65-67 (summarizing studies for markets other than the labor market to ascertain the price of fatal injuries). 
To avoid this problem, it is necessary to assume that an individual prices each mcrement of risk equally, "whether it is a change from .99999 to 1.0000 or a change from .00001 to $.00002 . " 217$ This assumption implies that an mdividual who requires $\$ 43.40$ for increasmg the risk of death by 1 im 100,000 prices her life in the context of this risk exchange at $\$ 4.34$ million. The assumption of this "limear preference" is highly dubious ${ }^{218}$ would an mdividual require only $\$ 43.40$ for mcreasmg the risk of death from .99999 to 1.0000 ? - but is necessary if an individual's (rather than the group's) excliange of money for a marginal risk of mjury is used to derive a monetary measure of the total mjury.

A related problem with using a marginal-risk measure to derive the price for an mjury is that the measure is subject to the reference-risk effect, so that individuals in market transactions probably undervalue such risk reductions or overvalue risk mcreases. ${ }^{219}$ Market studies that rely on marginal risk measures are thus likely to derive damage measures that understate or overstate the cost of injury.

Market studies are also subject to the criticism that, due to data limitations, they are unable to yield cost estimates for a range of injuries and risks. ${ }^{220}$ One way to circumvent this problem is to derive the price of nonfatal mjuries from the price of fatal mjuries. Yet, usmg (the inaptly named) "value of life" studies to determine the prices of nonfatal injuries create two difficult problems.

First, market studies lave yielded a wide range of estimates for the price that individuals place on their lives. Labor-market studies, for example, yield estimates ranging from $\$ 600,000$ to $\$ 16,200,000 .^{221}$ In theory, different populations will yield different prices for fatal mjuries in different contexts (due to differences in attitudes towards risk, wealth, and the degree of risk in question), ${ }^{222}$ but any scheduling approach that bases pam-andsuffering damages on these studies will need to determme what constitutes the best estimate of the price that individuals place on their lives in the face of a fatal risk.

Second, there are substantial difficulties in usmg the price of fatal injuries to derive damages for nonfatal imjuries. Such derivation requires that the nonfatal imjury be conceptualized as a percentage loss of life; for example, a severe injury might be equivalent to a fifty-percent functional impair-

217. Kornhauser, supra note 31, at 215.

218. See id. ("This assumption of linearity is clearly false; individual valuations of changes in risk will vary with the background risk that is modified.").

219. See supra notes 176-181 and accompanying text.

220. See VIScust, supra note 91, at 67 ("The principal limitation of compensating differential studies [based on actual market data] is that they do not pertain to all classes of risk that are of interest, and they may not always be sufficiently refined to enable us to perfectly isolate the risk-dollar tradeoff.").

221. See id. at 51-54 (providing summary of labor-market studies that estimate price of fatal risks).

222. See Komhauser, supra note 31; Viscusi, supra note 91, at 34-49. 
ment of life, so that the plaintiff should receive fifty percent of the damages available for a lost life. ${ }^{223}$ Not surprisingly, using the price of fatal risks in this manner raises a number of difficult issues. ${ }^{224}$

The final problein with inarket studies is that the risk-dollar measure for the price of nonfatal and fatal injuries is determined by healthy individuals atteinpting to assess the consequences of physical injury. As Ellen Smith Pryor has argued, it is extreinely unlikely that nondisabled individuals will have accurate information about their compensatory needs if disabled, and in any event, healthy individuals would be unable to use such information properly due to the difficulty of envisioning life with a disabling injury. ${ }^{225}$ If healthy individuals cannot accurately predict their compensation needs for pain-and-suffering injuries, then the risk-dollar tradeoffs provided by such imdividuals would not yield the proper price for the injury.

In sum, the substantial limitations inherent in market studies suggest that the awards to be used in a damages schedule should not be based upon these studies, particularly as other alternatives are available.

\section{Jury vs. Nonjury Surveys}

Due to the difficulty of deriving imjury prices from market studies, analysts have developed an alternative approach based upon survey methodology. Uulike the other approaches, survey methodology permits the formulation of questions to yield damages measures for specific risks and types of injuries. ${ }^{226}$ Thus, in principle the survey methodology could yield the appropriate awards for the range of injuries that must be incorporated into a schedule. The survey responses may not be reliable, however, smce the survey questions relate to hypothetical choices that may not be fully understood or taken seriously by the respondents. ${ }^{227}$ Consequently, surveymg lay individuals may not be a good source for devising a damages schedule for pain and suffering, so we ought to consider deriving the scheduled awards from prior jury awards.

223. The different ways that the price of fatal injuries can be used to determine damages for nonfatal injuries is discussed in Miller, supra note 18, at 896-98.

224. For a description of these problems, see Bovbjerg et al., supra note 3, at 951-52.

225. Pryor, supra note 100 , at $110-16$. This position finds support in studies showing that individuals are likely to do poorly in predicting how their tastes might change in response to changes in their circumstances. See Daniel Kahneman, New Challenges to the Rationality Assumption, $150 \mathrm{~J}$. InstimutionaL \& ThEORETICAL ECON. 18, 25-27 (1994).

226. Nevertheless, "[a]t the present state of our knowledge . . the risk valuation hiterature is not sufficiently extensive to place dollar values on each injury type that arises in court cases." Viscusi, supra note 38, at 218. Presumably, this literature could become sufficiently extensive if such studies were deemed to be a desirable method for deriving scheduled damages awards.

227. Indeed, for these reasons a number of commentators have concluded that survey methodology slould not be used for determining environmental damages. For a collection of articles that take this position, see Contrngent Valuation: A Critcal Assessment (Jetry A. Hausman ed., 1993) [hereinafter Contingent Valuation]. 
One way to evaluate the relative merits of jury awards in this regard is to develop David Leebron's suggestion that we view juries as a "survey mechanism." basis for scheduled awards if juries are in effect a better "survey mechanism" than the alternatives.

At present, basing a schedule on prior jury awards is problematic because the method juries use to calculate pam-and-suffering awards varies so much that it renders prior jury awards unreliable for scheduling purposes. ${ }^{229}$ However, if courts were to accept the method for deriving the $e x$ ante full-compensation award, then jury awards would, $\mathrm{m}$ principle, become a more reliable basis for deriving the scheduled awards. Adoptimg this approach would mean that scheduling could not presently be implemented (as there needs to be a sufficient number of prior jury determinations of the ex ante full-compensation award to make such a schedule feasible). Delaying the implementation of schedules would be desirable, though, since the ex ante full-compensation award may obviate the need for schedules. Moreover, since scheduled awards derived from surveys would also probably be determined by reference to a willingness-to-pay measure, there may be good reasons for preferring the jury's assessment of this measure. It is helpful in this regard to consider how jury determinations fare with respect to the following six problems that have been attributed to surveys that seek responses froin lay individuals regarding damages.

The first problein with relying on survey results to determine damages is that lay individuals may not have sufficient information about the injuries or harms that they are asked to evaluate. ${ }^{230}$ In contrast, jurors will have reviewed evidence on the nature and severity of the plaintiff's injury. Therefore, jurors will likely have a better appreciation for the consequences of the injury than would other healthy imdividuals faced with risk-dollar decisions in survey (and market) contexts. This factor indicates that jury determinations should provide more reliable responses than surveys.

On the other hand, because jurors are well informed about the consequences of injury, their assessments of the probability of injury may be unreliable. Studies have shown that mdividuals tend to disregard objective probabilities when risks are vivid or salient (the "availability heuristic"). 231 Jurors may therefore disregard the objective risk measure that they are told to use in the damages calculation and infer imstead from the vivid and salient nature of the plaintiff's mjury that the risk must be higher. For example, if jurors were told to determine the willingness-to-pay neasure $E(p)$ by

228. Leebron, supra note 18 , at 318-19.

229. See supra Part II.A.

230. See Steven Shavell, Contingent Valuation of the Nonuse Value of Natural Resources: Implications for Public Policy and the Liability System?, in Contingent Valuation, supra note 227, $371,374$.

231. See Latin, supra note 97 , at 1233-34. 
reference to a risk of 1 in 10,000 , because they have previously received evidence regarding the injury already incurred by the plaintiff, they could disregard the 1-in-10,000 risk measure and evaluate the injury by reference to a higher risk, say 1 in 1000 . This type of juror behavior would distort the damages calculation. Individuals are willing to pay more to eliminate higher risks, so the willingness-to-pay measure $E(p)$ is higher for a risk of 1 in 1000 than it is for a risk of 1 in 10,000. The damages award, however, would be computed on the basis of the objective risk measure given to jurors $(1$ in 10,000$)$. Hence, if jurors were influenced by the availability heuristic, they would overstate the damages award (as the measure $E(p)$ for a risk of 1 in 1000 would be multiplied by 10,000 rather than 1000).

It appears, then, that although individuals may give unreliable responses to survey questions regarding a hypothetical injury because they do not adequately appreciate the consequences of that injury, jurors may give unreliable responses to the damages question because they do in fact understand the consequences of the injury, which causes thein to overreact by overestimating the probability of suffering that injury. This suggests that there may be an inevitable tradeoff between understanding the consequences of injury (which makes it more salient and vivid) and properly assessing the risk which caused that imjury. On this view, there is no obvious reason to think that informational problems will result in jury determinations that are better or worse than the responses obtained by surveys.

The reliability of the jury award would be enhanced, however, if care were taken to help jurors properly contextualize the damages determination. The plaintiff's pain-and-suffering injury is vivid and salient to jurors because it has already happened and the jurors' attention is focused on that fact. It is thus necessary to reorient the jurors' attention from the injury itself, focusing instead on the relationship between that injury and the risk which caused it. For example, it would be leelpful to remind jurors in negligence cases that the defendant must pay for the plaintiff's injury because the defendant created an unreasonable risk, rather than the certainty, of injury. Stressing this point may help jurors to understand why they should not disregard the risk of injury when they make the damages determination. Jurors could also be given information regarding other types of accidents that may present a risk of magnitude similar to that used in the damages calculation but less subject to the availability heuristic. For example, if the damages calculation were based on a risk of 1 in 11,000 , then jurors could be told that there is a 1-in-11,000 annual risk that an individual will die from an accident in the home. ${ }^{232}$ Even if this information does not help to offset the availability heuristic, it would help jurors to understand better what a risk of 1 in 11,000 means, which should enhance the reliability of

232. See VIScuSI, supra note 128 , at 24 . 
jury determinations of the ex ante full-compensation award based on that objective measure of risk. ${ }^{233}$

In principle, surveys could also be constructed to help respondents understand fully the nature of the imjury assessment, but surveys are limited by the amount of time that they can reasonably require of respondents. In contrast, much more time can be spent on informing jurors how they should properly consider the damages calculation, which suggests that informational problems may ultimately be less of a problem for juries than for surveys.

The second problem with surveys is that the respondents may misrepresent their beliefs if they think they would benefit somehow by supplying maccurate answers. ${ }^{234}$ For example, individuals who know that survey results will be used to derive damage schedules may under- or over-represent their damage assessments based on their preferences for low or high tort awards. By contrast, the dainages determination at trial is focused on compensating the plaintiff, so it is less obvious why jurors in a given case will feel that they have something personal to gain by under- or over-representing their true assessinents of the appropriate dainages award. Again, this factor indicates that juries should provide more reliable responses than surveys.

Third, survey participants may lack the incentive to spend sufficient time to answer the questions carefully. ${ }^{235}$ Although jurors suffer no penalty for providing a damages award that they have not carefully considered, the award given by juries has a direct impact upon a particular injured individual about whom jurors will know something. This suggests that jurors are likely to consider the damages question carefully. Indeed, "[a] considerable body of research both on actual juries and in well controlled trial simulations supports the conclusion that juries make reasonable and rational decisions."236 Once agam, this factor indicates that jurors yield more reliable injury assessments than do survey respondents considering hypothetical imjuries. ${ }^{237}$

The fourth reason survey results may yield unreliable injury prices is that the respondents may provide answers that reflect irrelevant factors, such as a desire to please the interviewer. ${ }^{238}$ Similarly, one of the criticisms currently levied against juries is that their evaluation of pain-and-suffering

233. See Schwartz, supra note 13, at 382 ("[T] $]$ here is considerable evidence that people respond rationally to the provision of information about risk.").

234. See Shavell, supra note 230, at 374-75.

235. See id. at 375.

236. Saks, supra note 3 , at 1237.

237. See JACK HiRshLEIFER \& JoHN G. RILEY, ThE ANALYTICS OF UNCERTAINTY AND INFORMATION 35 (1992) ("Evidently, humans have trouble with purely abstract problems, but do a lot better when the logically equivalent choices are offered in a realistic context-particularly where possible cheating or violations of social norms may be involved.").

238. See Shavell, supra note 230 , at 375. 
injuries may reflect the influence of extralegal factors. ${ }^{239}$ Yet, because jurors at present are given very little guidance on how to calculate such damages, the problem may lie with the lack of legal standards rather than with the jury's decision-making process. ${ }^{240}$ This observation is borne out by studies showing that injury severity - the sole piece of evidence that juries are told to consider in their pain-and-suffering evaluations-is a good predictor of the size of a pain-and-suffering award.241 Studies have also shown that "[i]n general, the strength of the evidence presented at trial appears to be a major-perhaps the most important-determinant of the jury's verdict." ${ }^{\text {242 }}$ Thus, even thougl jurors in many cases probably do rely upon extralegal factors to some extent, ${ }^{243}$ it is not obvious that this problem is more pronounced for jurors than for lay individuals responding to survey questions.

Fifth, survey responses often depend on how the survey questions are posed. ${ }^{244}$ For example, changing the wording of the survey question will often change the amount of infornation available to the respondent, thus affecting her response. Althougli juries are also subject to such an influence, this problem is directly addressed by the adversarial system of litigation. Each party lias the ability to present evidence and to question the other party's evidence and inferences to be drawn therefrom. For this reason, this problem is likely to be much less severe for juries than for lay individuals answering survey questions.

The final reason to question the reliability of survey results is that they yield a wide range of prices for an identical imjury. ${ }^{245}$ This reason, in effect, summarizes the prior problems with survey methodology, as unreliable survey responses will be reflected in differing assessments of the same injury. Interestingly, despite the relative lack of guidance given to jurors, studies indicate that jury awards for pam-and-suffering imjuries presently exhibit a degree of variability similar to the observed variability in survey results. ${ }^{246}$

239. See supra text accompanying notes $43-45$.

240. See Kaplan \& Miller, supra note 44 , at 309-10 (describing study showing that relative to issues involving reasonably well-defined legal standards, juror discussions regarding punitive damages are more likely to involve normative, value-laden judgments than references to the evidence presented at trial).

241. See supra notes 38-39 and accompanying text.

242. MacCoun, supra note 3, at 162; see also Saks, supra note 3, at 1279 ("Evidence of injury severity has a greater effect on juror decisions than several of the most acclaimed modern medical treatments have on their objects.").

243. See supra note 44.

244. See Shavell, supra note 230 , at 376 .

245. Cf. id. at 376-77 (citing three studies attempting to measure the value of improving visibility at the Grand Canyon that yielded estimates of $\$ 9.5$ billion per year, $\$ 2.4$ to $\$ 3$ billion per year, and $\$ 2$ million to $\$ 50$ million per year).

246. See Bovbjerg et al., supra note 3, at $950 \mathrm{n} .188$ ("Overall, [the value-of-life] studies range at least as widely as jury awards, with less variation in what they purport to measure."); Leebron, supra note 21, at 316 (noting that variation of jury awards for pain and suffering observed in empirical study were "extremely close to the variation observed in survey values for environmental quality"). 
To the extent that implementation of the ex ante full-compensation award improves jury decision-making, the jury will likely yield more reliable damages awards than would surveys.

It should not be surprising that the jury is a good survey mechanisn. Although surveys are able to use the responses of a large number of individuals whereas jury determinations rely upon the assessments of a much smaller group, a jury award is the result of collective decision-making. The process of reaching a decision within a group may enhance the reliability of its final determination. Moreover, considerable resources are spent on providing jurors with the information that is relevant to the issue before them, and jurors are likely to take the task seriously simce the undertaking involves important civic responsibilities. These points are supported by studies that have shown juries do reasonably well in assessing awards as compared to the individualized assessinents of parties who are more likely to be expert on such matters-judges, arbitrators, and attorneys. ${ }^{247}$ In addition, as Michael Saks has observed,

One of the most interesting comparisons nay be to ask how the level of concordance between judges and juries conipares with data on other decision-makers, such as the rate of inter-judge agreement on sentencing, physician agreeinent on diagnosing illness, or scientific consensus on the merits of research proposals. The jury compares quite favorably against such benchmarks. ${ }^{248}$

As juries appear to be a better "survey inechanisin" than the alternatives, prior jury determinations of the ex ante full-compensation award would provide the best inethod for deriving the scheduled awards should it become necessary to resort to a damages schedule.

\section{CONCLUSION}

Pain-and-suffering damages have long given commentators ample opportunity to criticize the tort system and juries. Much of the criticisn is well placed, since the current systein does perform in an indefensible inanner. Although there is an evident need for reform, we should also recognize that inaction is not a viable alternative. As the tort reforms of the past decade have shown, the open-ended nature of pain-and-suffering awards nakes this element of dainages particularly vulnerable to legislative reforms that limit the availability of such damages. ${ }^{249}$ Consequently, if the courts do not adopt inore defensible inethods for determining pain-and-suffering dainages, it is likely that legislatures will place further limits on these dainages.

247. See Vidmar, supra note 6, at 260-61.

248. Saks, supra note 3 , at 1236.

249. For an analysis of why pain-and-suffering damages are vulnerable to legislative reforms that limit defendants' liability for such injuries, see Geistfeld, supra note 96, at 836-42. 
Limiting damages is not the solution, however, since it fails to address the underlying problem. As long as individuals incur paim-and-suffering injuries, the cost of these injuries will exist whether we atteinpt to ineasure them or not. Unless potential injurers are forced somehow to account for the cost of pain-and-suffering injuries, they will lack sufficient incentive to prevent these injuries from occurring. Hence the way we measure the cost of pain-and-suffering injuries, and the method by which we impose that cost upon injurers, will affect how many injuries occur. Improper ineasureinents will result in too many pain-and-suffering injuries, or in the alternative, excessively high liability costs that cause individuals and enterprises to forgo activities that are socially beneficial. There is no way to avoid the cost of these injuries, and so the ineasurement problen exists even if we choose to ignore it.

To be sure, it is not obvious how fully compensatory damages for a pain-and-suffering injury should be determined. Much of the difficulty lies in our inability to measure objectively the severity of an mdividual's painand-suffering imjury. However, this limitation does not mean that we cannot provide jurors with any guidance on how they should determine painand-suffering dainages. Nevertheless, jurors are not presently provided with the guidance that would help them to understand how injury severity should be translated into a monetary award. This lack of guidance creates a substantial problem for the current systen, as indicated by a recent study that asked lawyers in Georgia what they thought was "the single most troublesome issue to the jury" in the trial of a negligence case. ${ }^{250}$

The basic problem, respondents einphasized, was that "the jury is really not given a good road map for how to assess damages." There simply "is no good yardstick," "no real guidance" on calculating "an award of money damages." - More expansively, some answers highlighted particular damage translations as especially complex. Few were more complex, they overwhelmingly indicated, than "how to convert injury, pain, and suffering into dollar amounts."251

An obvious need exists for a method that would help juries determine tort damages for nonmonetary imjuries. I have tried to show that there is a defensible method for translating a pain-and-suffering injury into the appropriate monetary damages award. Perhaps the best way to assess the merits of my claim is to compare current jury instructions (which urge jurors to rely upon their "enlightened conscience" ${ }^{\text {"S2) }}$ with an instruction that first

250. R. Perry Sentell, Jr., The Georgia Jury and Negligence: The View from the Trenches, $28 \mathrm{G}_{\mathrm{A}}$. L. REv. 1, 97 (1993). The study consisted of a survey of trial lawyers in Georgia. Of those who responded, 122 categorized themselves as plaintiff's lawyers and 112 as defendant's lawyers. $I d$. at 11 .

251. Id. at 98.

252. See supra note 23 and accompanying text. 
explains and then tells jurors how to compute the ex ante full-compensation award for a negligence case:

To determine the appropriate sum of money for the plaintiff's paim-and-suffering injury, the law allows you to award the plaintiff a sum that will reasonably compensate her for any past physical pain, as well as pain that is reasonably certain to be suffered in the future as a result of the defendant's wrongdoing. For this reason, you should consider all the evidence bearing on the nature of the injuries, the certainty of future pain, the severity, and the likely duration thereof.

In determining the amount of these daniages, you should recognize that the defendant did not know for certain that the plaintiff would be injured, nor did the defendant intend for the plaintiff to be harmed. Rather, the defendant must pay for the plaintiff's injury because the defendant is legally responsible for the unreasonable risk of harm that caused the injury. Consequently, the damages award should equal the amount of money that a reasonable person would have accepted as fair compensation for the pain-and-suffering injury when confronted by the risk of suffering that injury.

You may assume that the defendant's wrongdoing resulted in the plaimtiff being exposed to a 1-in-10,000 risk of injury. This ineans that one injury identical to the plaintiff's pain-and-suffering injury would occur on average for every 10,000 times that an individual in the plaintiff's position was exposed to this risk. To determine what is fair compensation for the pain-and-suffering injury in light of this 1-in-10,000 risk, assume that a reasonable person is given the choice to purchase a safety device that would eliminate only this risk. If the individual purchased the safety device, she would continue to face the risk of suffering other imjuries, but the safety device would completely eliminate the 1 -in-10,000 risk that this imdividual would end up with a pain-and-suffering injury as severe as the plaimtiff's injury. In choosing between spending money on this safety device or facing this 1-in-10,000 risk of injury, a reasonable person would compare the cost of eliminating the risk witls the cost of the mjury that she might suffer if the safety device were not purchased. For this reason, the maximum amount that a reasonable person would be willing to pay to eliminate the risk of injury reflects that person's assessinent of the cost of the pain-andsuffering injury that would be avoided if the risk were eliminated.

This explains why you can determine the pain-and-suffering award by answering the following question: What is the nraximum amount of money that a reasonable person would have been willing to pay to eliminate the 1-in-10,000 risk of ending up with an injury as severe as the plaintiff's pain-and-suffering injury? Upon reach- 
ing an answer, if you inultiply the amount by 10,000 , you will get the amount of inoney that would fairly compensate the plaintiff for her pain-and-suffering injury.

The available evidence suggests that juries would do reasonably well at answering this question. The problems currently presented by pain-andsuffering damages thus do not necessarily imply that we ought to move these injuries outside the scope of the tort system or have a decisionmaker other than juries assess the-awards. Rather, perhaps all that we need to do is to ask jurors the right question.

\section{APPENDIX}

This Appendix sets out the analysis that supports a number of the conclusions discussed in the text. The analysis is developed with a mathematical inodel of the problem, although the conclusions and logic of the results are explained in nonmathematical terins. The notation to be used in the nodel is as follows:

$r=$ manufacturer's investments in safety per unit of product;

$c(r)=$ per-unit cost of a product with safety investments $r$; the

function is continuously differentiable with $c^{\prime}(r)>0$ and $c^{\prime \prime}(r)>0$; $p(r)=$ probability that the consuner will incur a productcaused injury froin a product with safety investments $r$; the function is contimuously differentiable with $p^{\prime}(r)<0$ and $p^{\prime \prime}(r)>0$;

$L=$ consunier's monetary loss (for example, lost income) resulting from a product-caused injury;

$M=$ payment froin inanufacturer to consumer for a productcaused injury;

$P=$ inarket price of the product;

$w=$ wealth of the consumer;

$V_{n}(w)=$ consumer's utility of wealth when there is no productcaused injury; the function is continuously differentiable with $V_{n}^{\prime}(w)$ $>0$ and $V_{n}^{\prime \prime}(w)<0$; and

$V_{f}(w)=$ consumer's utility of wealth when there is a productcaused injury (or, heuristically, a "product failure"); the function is continuously differentiable with $V_{f}^{\prime}(w)>0$ and $V_{f}^{\prime \prime}(w)<0$.

Consumer welfare is measured by the indirect utility function because liability rules provide only monetary damages as remedies for productcaused injuries. To capture the effect of nonmonetary injuries on consumer welfare, it is assumed that such injuries reduce the consunier's utility for any given level of wealth. A nonmonetary injury is thus characterized by a change in utility functions rather than by a change in wealth, with $V_{f}(w)<$ $V_{n}(w)$ for all levels of wealth $w$. A inonetary injury, by contrast, does not change the consunier's utility function, and so for such injuries $V_{f}(w)$ is identical to $V_{n}(w)$. 
The situation that will be analyzed is one in which the consumer has already decided to purchase a single unit of the product and needs to determine how much insurance should be purchased from the inanufacturer to compensate for product-caused mjuries. The analysis will assume that litigation costs are zero; the product injures only buyers (so that the consumer and the buyer are the same party); consumers cannot affect the probability or severity of injury; the severity of injury does not depend on the amount of inanufacturer safety investments $r$; and consumers are identical.

\section{The Case in Which Everyone is Perfectly Informed About Product Risks}

Manufacturer hability is not necessary for deterrence purposes when everyone is perfectly informed about product risks. Consequently, to assess the efficiency properties of manufacturer-provided insurance in this informational setting, we can assume that there is a fixed risk of injury. Assume for now that production costs $c(r)=0$ and that consumers, by paying an actuarially fair premium $p M$ to the manufacturer, can purchase the right to an insurance payout of $M$ in the event of injury. A consumer's expected utility $E V$ is given by

$E V=(1-p) V_{n}(w-p M)+p V_{f}(w-p M-L+M)$.

Optimizing with respect to $M$ yields the well-known result that optinal insurance equahizes marginal utilities across the potential states of the consumer's well-being:

$V_{n}^{\prime}(w-p M)=V_{f}^{\prime}(w-p M-L+M)$.

Recall that when the product causes only monetary injuries, $V_{n}(w)$ is identical to $V_{f}(w)$ and so $V_{n}^{\prime}(w)=V_{f}^{\prime}(w)$. Equation (2), then, is satisfied for monetary mjuries if $M=L$; that is, it is efficient for consumers to fully insure agamst monetary losses when insurance is actuarially fair.

This result does not hold when the consumer suffers a nonmonetary injury. Although this type of mjury alters the consumer's utility function so that $V_{f}(w)<V_{n}(w)$, the relationship between $V_{n}^{\prime}(w)$ and $V_{f}^{\prime}(w)$ is indeterminate. Thus, if the injury is completely nonmonetary $(L=0)$, then equation (2) shows that the efficient amount of insurance (the value of $M$ that solves this equation) is positive, negative, or zero, depending on whether marginal utility is increased, decreased, or left unchanged by the product accident. (Recall that the marginal utility of wealth decreases with increases in wealth.) Note, though, that when the injury increases the victim's marginal utility of wealth, the efficient amount of insurance, while positive, will often be less than the amount that would fully compensate the viction for the paim-and-suffering injury. ${ }^{253}$

253. See Shavell, supra note 48, at 246. 


\section{A Case of Imperfect Information}

Assume that prior to purchasing the product, consumers are unable to observe the amount of the inanufacturer's investments in product safety, and that consumers do not have access to other kinds of information that would make them well informed about the unobservable safety characteristics of the products in question. Markets of this type are subject to the problein of manufacturer moral hazard, which means that a manufacturer's incentive to make costly safety investments stens only from the amount of its ex post liability payments to the consumer. ${ }^{254}$ Thus, given the level of insurance payment $M$, the producer, whatever its market power, will choose its safety investments $r$ so as to maximize $\Pi$, the profits per sale, where $\Pi=P-c(r)-p(r) M$.

Optimizing with respect to $r$ shows that for a given $P$ and $M$, profits are naximized at the point where $c^{\prime}(r)=-p^{\prime}(r) M$.

Applying the implicit-function theorem yields

$\frac{\partial r}{\partial M}=\frac{-p^{\prime}(r)}{M p^{\prime \prime}(r)+c^{\prime \prime}(r)}>0$.

The manufacturer's safety investments therefore increase as its liability to consumers for product-caused injuries mcreases; that is, $r$ is implicitly defined by the level of insurance payout $M$. (To avoid nested parentheses, functional dependence will not appear explicitly unless relevant.) Manufacturer liability for product-caused injuries accordingly yields two benefits in this setting: it provides insurance to the consumer and gives the manufacturer an incentive, which would otherwise be lacking, to make costly investments im product safety. Determining the benefits of manufacturerprovided insurance will consequently depend in part on how the amount of product safety is affected by the amount of insurance.

In this market setting, social welfare is maximized by the amount of manufacturer-provided insurance $M$ that maximizes the buyer's expected utility $E V$ for a given level of manufacturer profits $\Pi_{0}$. That is, social welfare is maximized by the value of $M$ that maximizes the following expression subject to equation (4) above:

$$
\begin{aligned}
E V= & {[1-p(r)] V_{n}\left(w-c(r)-p(r) M-\Pi_{0}\right) } \\
& +p(r) V_{f}\left(w-c(r)-p(r) M-\Pi_{0}-L+M\right) .
\end{aligned}
$$

In order to focus on nonmonetary injuries and to simplify, let $L=0$ and $\Pi_{0}=0$. The first-order condition for equation (6) is

254. For a more extensive analysis of this problem, see Mark Geistfeld, Manufacturer Moral Hazard and the Tort-Contract Issue in Products Liability, 15 INT'L REv. LAw \& ECoN. (forthcoming 1995). 


$$
\begin{aligned}
\frac{\partial E V}{\partial M}= & -p^{\prime}(r) \frac{\partial r}{\partial M} V_{\mathrm{n}}(\bullet) \\
& +[1-p(r)]\left[-c^{\prime}(r) \frac{\partial r}{\partial M}-p^{\prime}(r) \frac{\partial r}{\partial M} M-p(r)\right] V_{n}^{\prime}(\bullet) \\
& +p^{\prime}(r) \frac{\partial r}{\partial M} V_{f}(\bullet) \\
& +p(r)\left[-c^{\prime}(r) \frac{\partial r}{\partial M}-p^{\prime}(r) \frac{\partial r}{\partial M} M-p(r)+1\right] V_{f}^{\prime}(\bullet) \\
& =0 .
\end{aligned}
$$

For a given level of $M$, the firm will set $r$ to satisfy equation (4). Thus, $c^{\prime}(r)+p^{\prime}(r) M=0$ as given by equation (4) can be substituted into equation (7). Using the expression for the market price of the product $P$ given in equation (3) and rearranging yields

$p(r)[1-p(r)]\left[V_{n}^{\prime}(w-P)-V_{f}^{\prime}(w-P+M)\right]$

$$
=-p^{\prime}(r) \frac{\partial r}{\partial M}\left[V_{n}(w-P)-V_{f}(w-P+M)\right] \text {. }
$$

Equation (8) defines the optimal level of manufacturer liability when manufacturer-provided insurance provides both compensation for productcaused injuries and an imcentive to inanufacturers to increase their investments in product safety. This amount of insurance will be called the "second best" amount of insurance in order to contrast it with the "first best" amount of insurance that is optimal under conditions of perfect information.

As shown by equation (2) above, the first-best amount of insurance equates marginal utilities in the injured and nominjured states. Thus, the left-hand side of equation (8) defines the marginal cost of the "excessive insurance" used to induce greater inanufacturer safety investments, where "excessive insurance" refers to the amount of insurance above the first-best amount. The right-hand side of equation (8) defines the marginal benefit of the increased product safety induced by the "excessive insurance."

If the nonmonetary injury decreases the marginal utility of wealth so that $V_{n}^{\prime}(w)>V_{f}^{\prime}(w)$, full compensation would not be optimal. This is because full compensation is the amount $M>0$ such that $V_{n}(w-P)=V_{f}(w$ $-P+M)$. A positive amount of compensation implies that $V_{n}{ }^{\prime}(w-P)>$ $V_{f}^{\prime}(w-P+M)$ due to the declining marginal utility of wealth, so equation (8) cannot be satisfied at the level of full compensation.

While less than the amount of full compensation, the amount of second-best imsurance can be positive even though the first-best insurance amount is negative for injuries that decrease the marginal utility of wealth. To see this, substitute the expression for $\partial r / \partial M$ from equation (5) imto equation (8), and then solve for $M$. 
$M=\left[\frac{p^{\prime}(r)\left[V_{n}(w-P)-V_{f}(w-P+M)\right] p^{\prime}(r)}{p(r)[1-p(r)]\left[V_{n}^{\prime}(w-P)-V_{f}^{\prime}(w-P+M)\right]}-c^{\prime \prime}(r)\right] \frac{1}{p^{\prime \prime}(r)}$.

As full compensation is not optimal, the second-best amount of insurance will yield $V_{n}(w-P)>V_{f}(w-P+M)$. If the pain-and-suffering injury reduces the marginal utility of wealth, then $V_{n}{ }^{\prime}(w-P)>V_{f}^{\prime}(w-P+M)$. The amount of second-best insurance therefore is negative only if $c^{\prime \prime}(r)$ is sufficiently large to make the bracketed expression negative. There will, then, be cases $\dot{m}$ which the second-best insurance amount is positive even though the first-best amount is negative. ${ }^{255}$ Moreover, although it has been assumed that $c^{\prime \prime}(r)>0$, it is conventional to assume that there are constant marginal costs of precaution. ${ }^{256}$ When $c^{\prime \prime}(r)=0$, the second-best amount of imsurance as given by equation (9) will always be positive even though the first-best amount of insurance is negative.

\section{Properties of the Second-Best Insurance Payout: The Severity of the Nonmonetary Injury}

When the nonmonetary injury does not affect the marginal utility of wealth, it can be represented by $V_{f}(w)=V_{n}(w)-k$, where $V_{n}(w)>k>0$. For injuries of this type, increases in $k$ represent increases in injury severity. Substituting this expression for $V_{f}(w)$ into equation (9) shows that the second-best insurance payout increases as imjuries of this type become mcreasingly severe. As a general matter, however, the second-best insurance payout does not necessarily increase with increases in injury severity.

Injury severity has an ambiguous effect on the second-best insurance payout because severity encompasses two dimensions-the effect on total utility and the effect on marginal utility - and each of these dimensions affects the second-best insurance payout in an opposite manner. (As indicated by equation (9), imcreasingly severe imjuries in the total utility dimension increase the second-best insurance payout whereas increasingly severe injuries in the marginal utility dimension decrease the second-best insurance payout.)

\section{Calculating Full Compensation for Nonmonetary Injuries}

We have found that the second-best amount of insurance for nonmonetary injuries is not equal to the level of full compensation if the nonmonetary injury reduces the consumer's marginal utility of wealth. However, the

255. The analysis in this section up to this point bas been an extension of Rea, supra note 99. Rea's analysis did not address the issues that are the subject of the remainder of this Appendix.

256. See, e.g., Winand Emons, Warranties, Moral Hazard, and the Lemons Problem, 46 J. EcoN. THEORY 16, 20 (1988), which uses an assumption of constant marginal costs of precautions. The assumption of constant marginal costs of precautions is conventional because it is necessary if competitive markets subject to a rule of no producer liability are to attain the socially optimal level of output and product quality under conditions of full information about product risks. See DaNIEL F. SpUlber, REgulation aNd Markets 402 (1989). 
data needed to compute the second-best level of insurance as given by equation (9) will probably not be available for most cases, and estimating the second-best amount of damages on the basis of mjury severity alone is unlikely to yield the appropriate damages measure. Moreover, the solution given by equation (9) would not be optimal if consumers were otherwise mefficiently underinsured for other mjuries that they might suffer, since manufacturer-provided imsurance has a benefit in such situations that is not captured by the analysis in section 2 above. For these and other reasons given in the text, ${ }^{257}$ a fully compensatory award may be the most efficient, feasible approach.

To determine the amount of full compensation, define $E(p)$ as the maximum amount that the consumer is willing to pay to reduce the probability of product accident froin $p(r)$ to zero. The magnitude of $E(p)$ will depend upon the consumer's expected utility prior to the elimination of the risk, which in addition to $p(r)$ depends upon the severity of the injury and the amount of insurance that the consumer has purchased to compensate for the mjury. More formally, the definition of $E(p)$ implies that

$V_{n}(w-E(p))=(1-p) V_{n}(w-p M)+p V_{f}(w-p M+M)$.

Define $M_{f}$ as the full-compensation imsurance payout, which is the amount of money that equalizes the consumer's utility across the noninjured and injured states. In forinal ternns,

$V_{n}\left(w-p M_{f}\right)=V_{f}\left(w-p M_{f}+M_{f}\right)$.

Substituting this expression into equation (10) yields

$V_{n}(w-E(p))=V_{n}\left(w-p M_{f}\right)$.

It follows from equation (12) that $E(p)=p M_{f}$, and so the amount of full compensation is given by

$\frac{E(p)}{p}=M_{f}$

Thus, when manufacturer-provided insurance is set at the level of full compensation, the consumer's willingness to pay to eliminate the risk entirely will equal the actuarially fair premium for the insurance policy. The same result occurs for purely monetary losses. ${ }^{258}$

Note that this analysis does not apply to the case in which $V_{f}(\bullet)=$ $V_{f}^{\prime}(\bullet)=0$. For this type of injury, money is of no value to the victim following the accident, and so no amount of monetary compensation provided to the consumer can meet the definition of full compensation given above; that is, there is no insurance payout $M$ that can equate $V_{f}(\bullet)$ and $V_{n}(\bullet)$.

257. See supra Part IV.

258. In this case, $V_{n}(w-E(p))=(\mathrm{I}-p) V_{n}(w-p M)+p V_{n}(w-p M+M-L)$. At full compensation, $M_{f}=L$, and thus $E(p)=p M_{f}$. 


\section{Properties of the Ex Ante Full-Compensation Award}

\section{A. Probability of Injury}

Let the probability of injury be given by $(1+\lambda) p(r)$ with $0 \leq(1+\lambda) p(r)$ $\leq 1$, so that $\lambda>0$ represents an exogenous increase in the probability of injury and $\lambda<0$ represents an exogenous decrease in the probability of injury. By applying the inplicit-function theorem to equation (11), we can find how changes in $\lambda$ affect the amount of full compensation. ${ }^{259}$ (Recall that $r$ is implicitly defined by $M$.)

$$
\frac{\partial M_{f}}{\partial \lambda}=\frac{p M_{f}\left[V_{n}^{\prime}(\bullet)-V_{f}^{\prime}(\bullet)\right]}{-(1+\lambda) p(1+e)\left[V_{n}^{\prime}(\bullet)-V_{f}^{\prime}(\bullet)\right]-V_{f}^{\prime}(\bullet)} .
$$

In this expression, $e$ denotes the elasticity of the probability of injury with respect to damages; that is,

$$
e=\left(\frac{M_{f}}{p}\right)\left(\frac{\partial p}{\partial r} \frac{\partial r}{\partial M}\right)<0 .
$$

Whether $|e|>1$ affects the sign of equation (13). However, when $|e|>1$, the consumer could actually reduce the insurance premium by increasing the amount of the imsurance payout. (The proportional increase in the payout would lead to a proportionally larger decrease in the risk of injury, thereby lowering the overall premium.) Presumably, the consumer would always choose to increase the insurance payout until such increases no longer reduced the overall premium, so we can assume that $|e| \leq 1$.

When $V_{n}^{\prime}(\mathrm{w})>V_{f}^{\prime}(w)$, then at the level of full compensation $V_{n}^{\prime}(\cdot)>$ $V_{f}^{\prime}(\bullet)$. Equation (13) therefore is always negative for these injuries; in other words, the level of full compensation will always decrease with exogenous increases in the probability of injury.

The logic behind this result is most easily illustrated by the case in which the amount of the insurance payout does not affect the probability of mjury (so that $e=0$ ). In this case, an exogenous increase in the probability of injury will decrease the level of full compensation because, standing alone, the imcreased probability of injury increases the insurance premium by an equal amount in both the pre- and post-accident states. Although the level of wealth is reduced by the same amount in eacli state, if the marginal utility of wealth is higlier in the pre-accident state, then the imcreased insurance premium causes a greater reduction in total utility in the pre-accident state than in the post-accident state. To equalize utility levels in both states (as required by the definition of full compensation), the consumer needs to reduce the amount of compensation received in the post-accident state.

259. We also need to rely upon the additional assumption that the denominator of equation (13) is not zero in a neighborhood of points that satisfy equation (11). This will be true whenever $|e| \leq 1$, which is plausible for reasons to be given shortly. 
Note that this "wealth effect" will not be significant when the premium mvolves a small sum of money in relation to the consumer's wealth, since small moreases in the risk of mjury will increase the premium by an insignificant amount. Such insignificant premium increases will most likely occur when the probability of mjury is small or the injury is not very severe.

This wealth effect is slightly enhanced by the way in which the amount of manufacturer-provided insurance affects the probability of injury. For example, by changing $e=0$ to $e=(-1)$, the absolute value of the inagnitude of the denominator in equation (13) is reduced, thereby increasing the absolute value of the entire equation (which remains negative). In this case, when the consumer reduces the amount of the insurance payout due to the wealth effect caused by the increased probability of injury, the reduced amount of manufacturer liability diminishes the manufacturer's incentive to supply safety, which in turn further increases the risk of injury. This secondary influence on the risk of injury- "the deterrence effect"- then forces the consumer to reduce further the amount of the insurance payout.

The deterrence effect will be very slight for small risks of injury, since the inagnitude of the term containing $e$ in equation (13) will be very small in relation to the other term in the denominator. Thus, both the wealth and deterrence effects should be insignificant when the probability of injury is quite small, and so a damages calculation that relies upon a small probability of injury should yield a reasonably good estimate of what the award would be if the true (and, presumably, small) risk of injury were used in the damages calculation. ${ }^{260}$

\section{B. Severity of Injury}

To see how the severity of injury affects the amount of full compensation, let $0<V_{f}(w)=\gamma V_{n}(w)-k<V_{n}(w)$. Note that changes in the consumer's marginal utility of wealth caused by an injury of the form $V_{f}^{\prime}(w)=$ $\gamma V_{n}^{\prime}(w)$ are captured by this expression for $V_{f}(w)$. Substituting this expression for $V_{f}(w)$ into equation (10) yields

$V_{n}(w-E(p))=(1-p) V_{n}\left(w-p M_{f}\right)+\gamma p V_{n}\left(w-p M_{f}+M_{f}\right)-p k$.

Reductions in the consumer's expected utility given by the right-hand side of this equation will mcrease $E(p)$. Thus, it is apparent by inspection that $E(p)$ will increase with increases in the severity of the pain-andsuffering mjury (that is, with increases in $k$ or decreases in $\gamma$ ). The increase in $E(p)$ in turn miplies that the level of full compensation imcreases with mcreases in the severity of injury.

It is not apparent by inspection why the full-compensation amount increases as the accident causes increasingly severe reductions in the

260. One empirical study has found that "increases in the base risk reduced the implicit value of [a nonfatal] injury. The empirical sensitivity of the results to the base risk level was not, however, great." Viscusi \& Evans, supra note 89, at 372. 
marginal utility of wealth. The logic behind this result is straightforward, however. For a given reduction in total utility caused by the injury, for increasingly larger reductions in the individual's marginal utility (that is, with decreases in $\gamma$ ), more and more dollars are needed following the accident to compensate for the reduction im total utility. The amount of full compensation therefore increases as the mjury causes greater reductions in the inarginal utility of wealth.

\section{Extending the Analysis to Noncontractual Relationships}

The model developed above can be apphed to situations in which the injurer and victim are not im a contractual relationship. Assume that individuals are identical and engaged in a composite of risk-creating activities. The only possible mjuries are nonmonetary ones. Given the range of activities, each individual is both a potential injurer and a potential victim, so that in any given accident an individual may be either an imjurer, a victim, or both an injurer and victim. Finally, assume that all impose a risk of equal magnitude upon each other and that all victims suffer equally severe (nonmonetary) injuries.

The notation to be used in the formal model is as follows:

$r=$ amount of prevention or precautions taken by an individual;

$c(r)=$ cost per unit of prevention $r$, with $c^{\prime}>0$ and $c^{\prime \prime}>0$;

$p(\hat{r})=$ probability that an individual will be imjured by someone

else who has taken the amount of prevention or precautions $\hat{r}$, with $p^{\prime}<0$ and $p^{\prime \prime}>0$;

$M=$ tort payment from the injurer to the victim;

$B=$ monetary equivalent of the benefit that an individual

derives from engaging in the activity;

$w=$ wealth of an individual;

$V_{n}(w)=$ an individual's utility of wealth when not injured; and

$V_{f}(w)=$ an individual's utility of wealth after being injured.

If we consider only the equilibrium in which all individuals act in the same manner (so that $r=\hat{n}$ ), then the efficient level of tort damages will maximize the expected utility of each individual given the (identical) actions of the other individuals. ${ }^{261}$ Whether the individual suffers an injury or not, she faces expected liability costs equal to $p(r) M$ for the injuries that she may cause others. Each individual's expected utility is therefore given by

$E V=[1-p(r)] V_{n}(w+B-c(r)-p(r) M)+p(r) V_{f}(w+B-c(r)-p(r) M+M)$.

To simplify, assume that $B=0$. Note that equation (15) is now identical to equation (6) above (when $\Pi_{0}=0$ ). The analysis thereafter proceeds in identical fashion because the structure of the problem remains the same. In both cases, tort hability gives potential injurers an incentive,

261. See Arlen, supra note 183, at 91. 
which is assumed to be otherwise lacking, to take costly measures that reduce the likelihood of injury. Tort liability is also beneficial in both contractual and noncontractual settings because it provides potential victims with coinpensation (insurance) for their injuries. However, as is true in contractual settings, tort liability in the context of noncontractual relationships also imposes a cost on potential victims, though in this instance it is due to the possibility that as an injurer, the individual will have to pay for someone else's injury. 